\title{
Decontamination and Decommissioning of the Experimental Boiling Water Reactor (EBWR): Project Final Report, Argonne National Laboratory
}

Decontamination and Decommissioning Program

Argonne National Laboratory 9700 South Cass Avenue Argonne, Illinois 60439
Operated by The University of Chicago, under Contract W-31-109-ENG-38, for the United States Department of Energy 


\section{Argonne National Laboratory}

Argonne National Laboratory, with facilities in the states of Illinois and Idaho, is owned by the United States Government, and operated by the University of Chicago under the provisions of a contract with the Department of Energy.

This technical memo is a product of Argonne's Technology Development Division, Decontamination and Decommissioning Program. For information on the division's activities, contact:

Director, Technology Development Division

Argonne National Laboratory Argonne, llinois 60439-4815

Telephone (630) 252-6050

Presented in this technical memo are preliminary results of ongoing work or work that is more limited in scope and depth than that described in formal reports issued by the Technology Development Division.

Publishing support services were provided by Argonne's Information and Publishing Division (for more information, see IPD's home page: http://www.jpd.anl.gov/).

\section{Disclaimer}

This report was prepared as an account of work sponsored by an agency of the United States Government. Neither the United States Government nor any agency thereof, nor any of their employees, makes any warranty, express or implied, or assumes any legal liability or responsibility for the accuracy, completeness, or usefulness of any information, apparatus, product, or process disclosed, or represents that its use would not infringe privately owned rights. Reference herein to any specific commercial product, process, or service by trade name, trademark, manufacturer, or otherwise, does not necessarily constitute or imply its endorsement, recommendation, or favoring by the United States Government or any agency thereof. The views and opinions of authors expressed herein do not necessarily state or reflect those of the United States Government or any agency thereof.

Available to DOE and DOE contractors from the Office of Scientific and Technical Information, P.O. Box 62, Oak Ridge, TN 37831; prices available from (423) $576-8401$

Available to the public from the National Technical Information Service, U.S. Department of Commerce, 5285 Port Royal Road, Springfield, VA 22161. 


$$
A N \alpha / D-D / T M-96 / A
$$

\section{Decontamination and Decommissioning of the Experimental Boiling Water Reactor (EBWR): Project Final Report, Argonne National Laboratory}

by C.R. Fellhauer, L.E. Boing, and J. Aldana*

Decontamination and Decommissioning Program, Technology Development Division, Argonne National Laboratory, 9700 South Cass Avenue, Argonne, Illinois 60439

Work sponsored by United States Department of Energy, Office of Environmental Management 
6

This report is printed on recycled paper. 


\section{DISCLAMMER}

Portions of this document may be illegible in electronic image products. Images are produced from the best available original document. 


\section{CONTENTS}

NOTATION $\ldots \ldots \ldots \ldots \ldots \ldots \ldots \ldots \ldots \ldots \ldots \ldots \ldots \ldots \ldots \ldots \ldots \ldots \ldots \ldots \ldots$

ACRONYMS, INITIALISMS, AND ABBREVIATIONS $\ldots \ldots \ldots \ldots \ldots \ldots \ldots \ldots \ldots$ ix

SUMMARY $\ldots \ldots \ldots \ldots \ldots \ldots \ldots \ldots \ldots \ldots \ldots \ldots \ldots \ldots \ldots \ldots \ldots \ldots \ldots$

$1 \quad$ PROJECT OBJECTIVE $\ldots \ldots \ldots \ldots \ldots \ldots \ldots \ldots \ldots \ldots \ldots \ldots \ldots \ldots \ldots \ldots$

2 FACILITY DESCRIPTION AND HISTORY $\ldots \ldots \ldots \ldots \ldots \ldots \ldots \ldots \ldots \ldots$

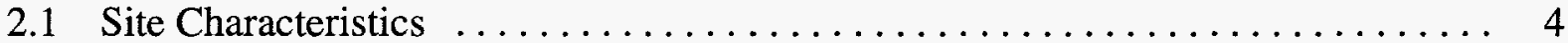

2.2 Facility Background $\ldots \ldots \ldots \ldots \ldots \ldots \ldots \ldots \ldots \ldots \ldots \ldots \ldots \ldots \ldots$

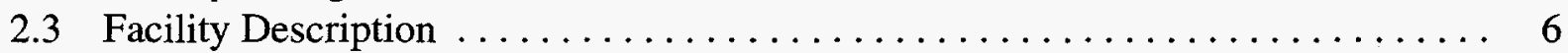

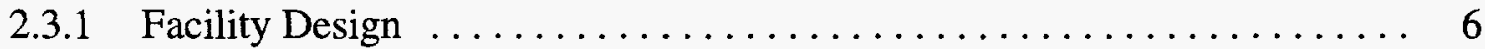

2.3.2 Reactor Pressure Vessel and Internals $\ldots \ldots \ldots \ldots \ldots \ldots \ldots \ldots \ldots \ldots$

2.3 .3 Main Floor . . . . . . . . . . . . . . . . . . . . . . . . . . . 11

2.3.4 Condenser Floor $\ldots \ldots \ldots \ldots \ldots \ldots \ldots \ldots \ldots \ldots \ldots \ldots \ldots \ldots \ldots \ldots \ldots$

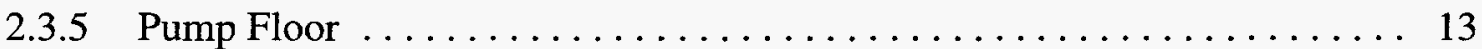

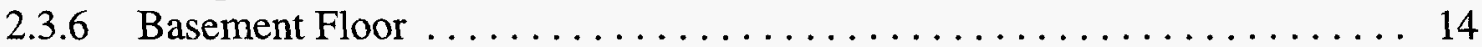

2.3.7 EBWR under Dry Lay-Up Conditions $\ldots \ldots \ldots \ldots \ldots \ldots \ldots \ldots \ldots \ldots$

2.4 Overview of the EBWR D\&D Project $\ldots \ldots \ldots \ldots \ldots \ldots \ldots \ldots \ldots \ldots$

3 D\&D PROJECT ENGINEERING AND PLANNING $\ldots \ldots \ldots \ldots \ldots \ldots \ldots \ldots$

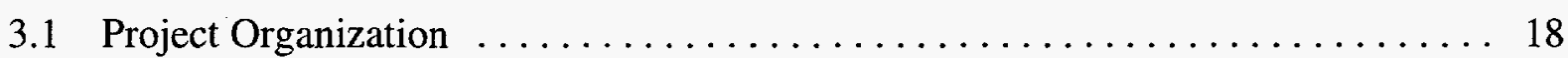

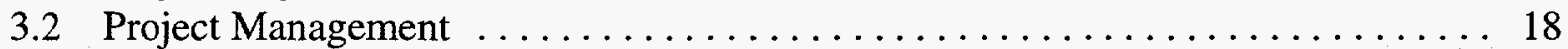

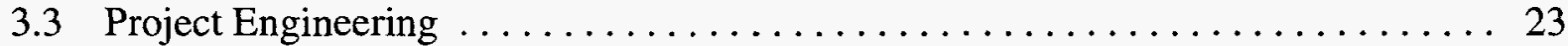

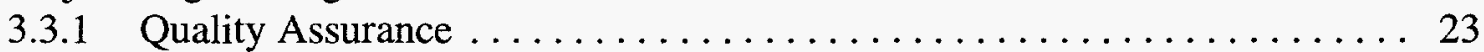

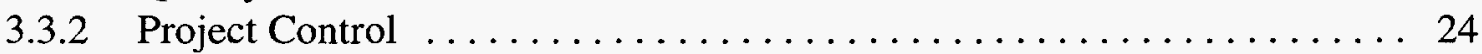

3.3 .3 Project Data . . . . . . . . . . . . . . . . . . . . . 24

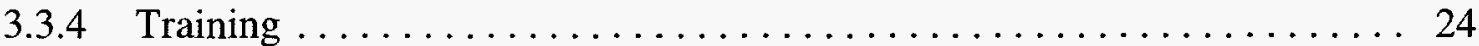

3.3.4.1 Health Physics .......................... 24

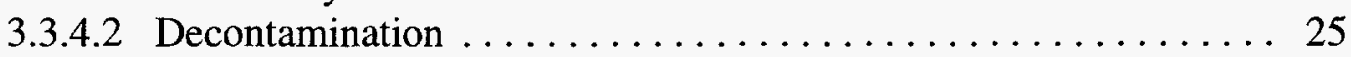

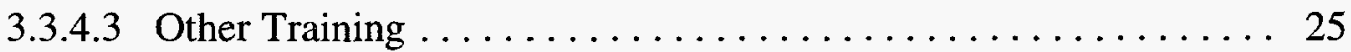

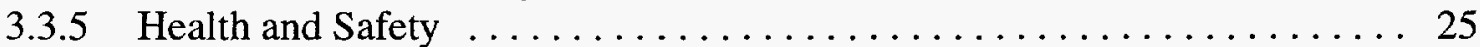

3.3.5.1 Planning and Review Committee ................. 25

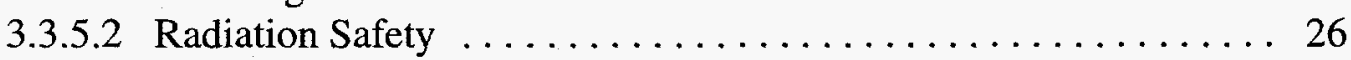

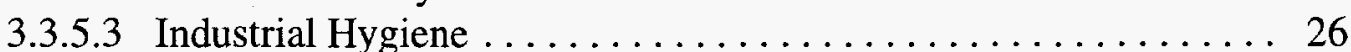

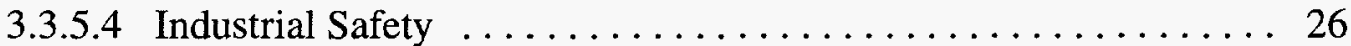

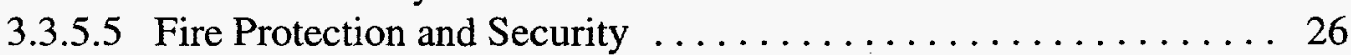

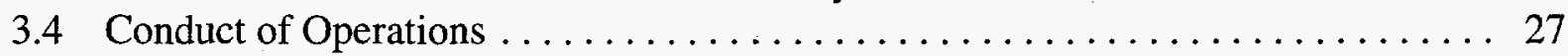

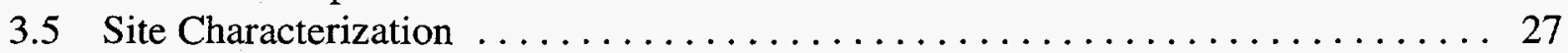

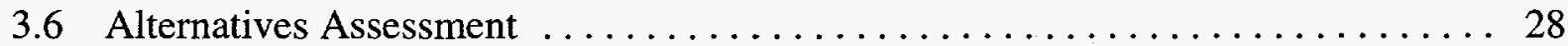




\section{CONTENTS (Cont.)}

4 DECOMMISSIONING OPERATIONS

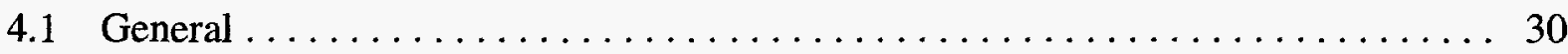

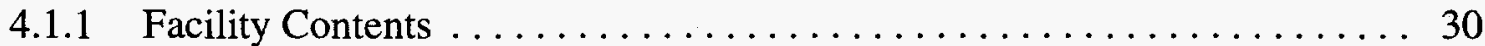

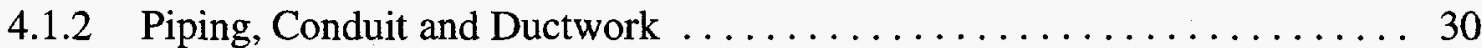

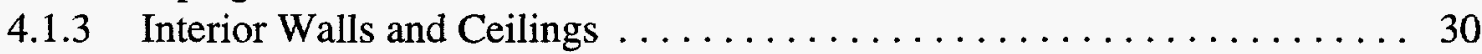

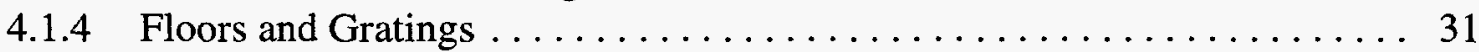

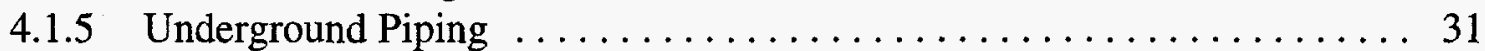

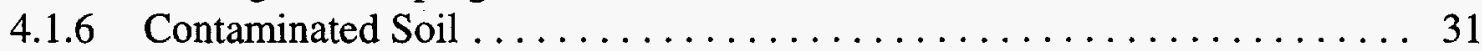

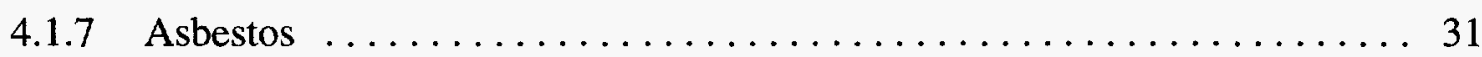

4.2 Phase I - Preparatory Activities $\ldots \ldots \ldots \ldots \ldots \ldots \ldots \ldots \ldots \ldots \ldots \ldots \ldots$

4.3 Phase II - Reactor System Piping, Components and Associated Equipment . . . . 34

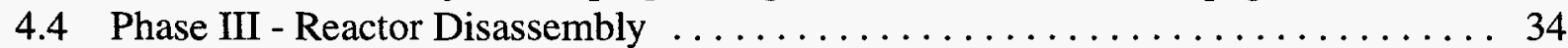

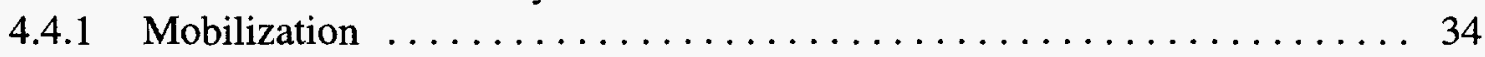

4.4 .2 Phase IIIA - Reactor Vessel Internals .................. 37

4.4 .3 Phase IIIB - Reactor Vessel . . . . . . . . . . . . . . . . . . . . . 45

4.5 Phase IV - Biological Shield $\ldots \ldots \ldots \ldots \ldots \ldots \ldots \ldots \ldots \ldots \ldots \ldots \ldots \ldots \ldots$

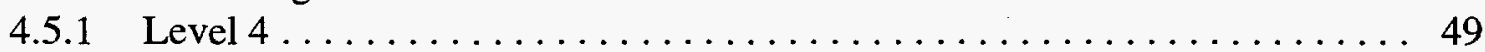

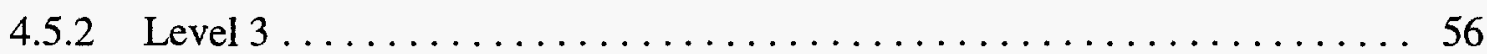

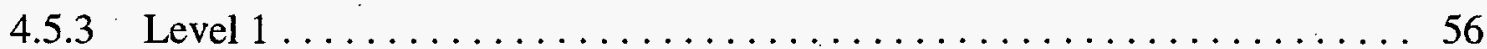

4.5 .4 Multiple Levels $\ldots \ldots \ldots \ldots \ldots \ldots \ldots \ldots \ldots \ldots \ldots \ldots \ldots \ldots \ldots \ldots$

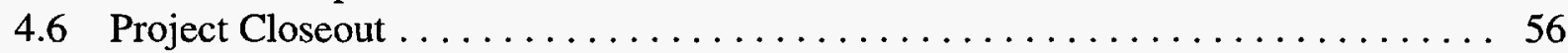

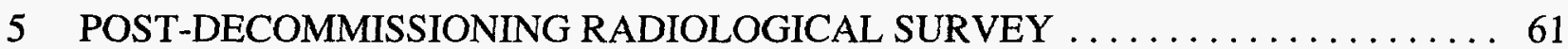

5.1 Final Survey Objectives $\ldots \ldots \ldots \ldots \ldots \ldots \ldots \ldots \ldots \ldots \ldots \ldots \ldots \ldots \ldots$

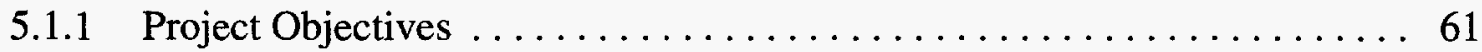

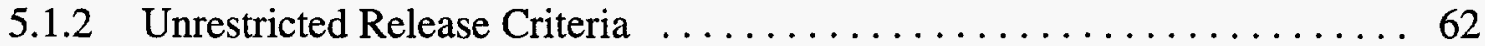

5.2 Final Survey Approach $\ldots \ldots \ldots \ldots \ldots \ldots \ldots \ldots \ldots \ldots \ldots \ldots \ldots \ldots \ldots \ldots$

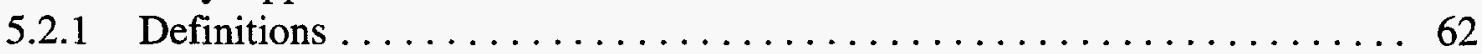

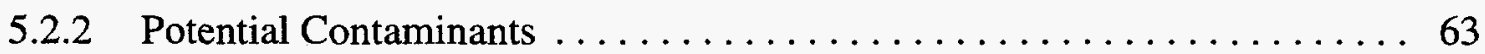

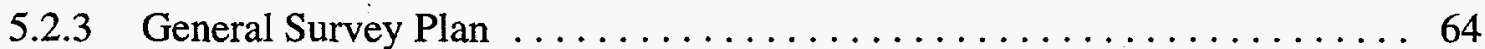

5.3 Reference Grid System $\ldots \ldots \ldots \ldots \ldots \ldots \ldots \ldots \ldots \ldots \ldots \ldots \ldots \ldots \ldots$

5.4 Survey Instrumentation $\ldots \ldots \ldots \ldots \ldots \ldots \ldots \ldots \ldots \ldots \ldots \ldots \ldots \ldots \ldots \ldots$

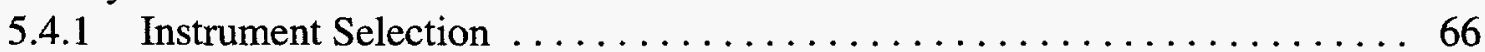

5.4 .2 Determination of Counting Times $\ldots \ldots \ldots \ldots \ldots \ldots \ldots \ldots \ldots \ldots$

5.4.3 Daily Instrument Function Tests and Quality Assurance ........... 68

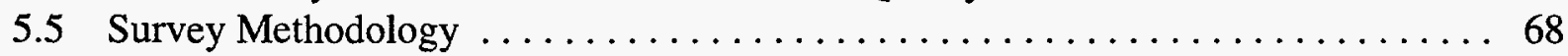

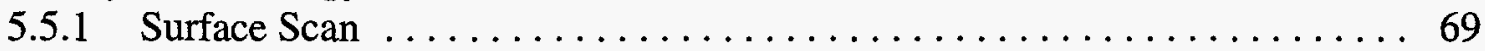

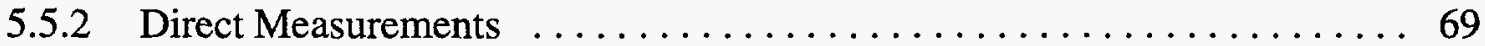

5.5.3 Removable Contamination Measurements .................. 69

5.5 .4 Exposure Rate Measurements . . . . . . . . . . . . . . . . 70

5.5.5 Special Measurements and Sampling $\ldots \ldots \ldots \ldots \ldots \ldots \ldots \ldots$ 


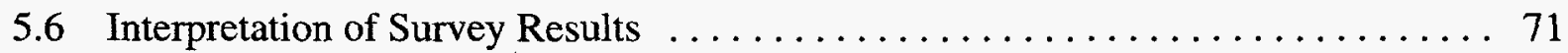

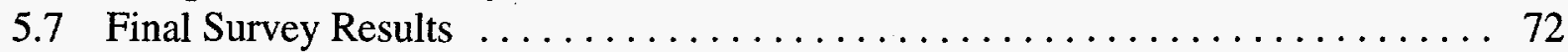

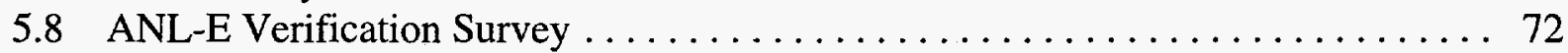

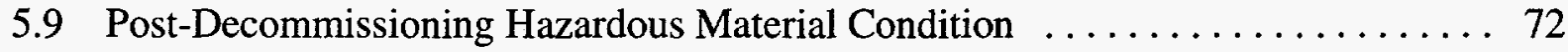

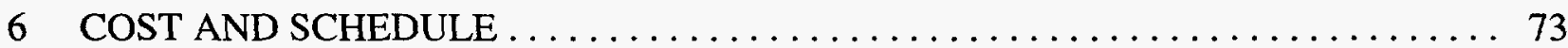

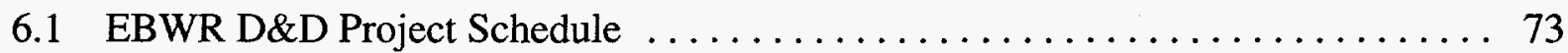

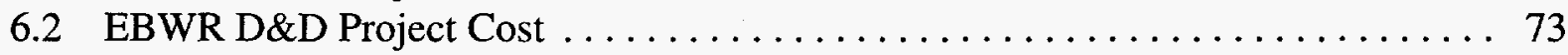

6.3 EBWR D\&D Project Exposure Summary ................... 73

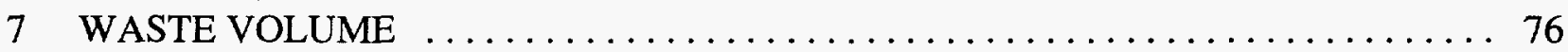

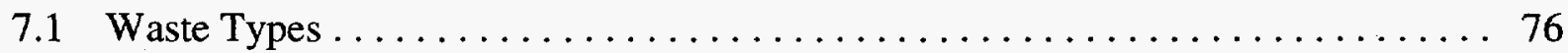

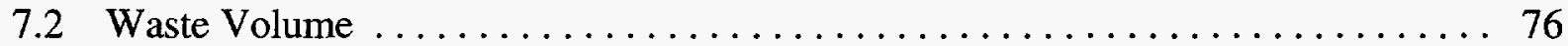

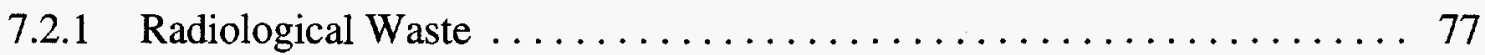

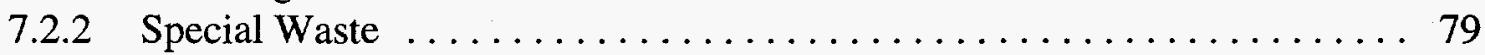

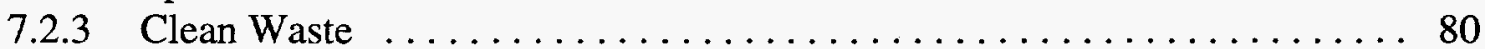

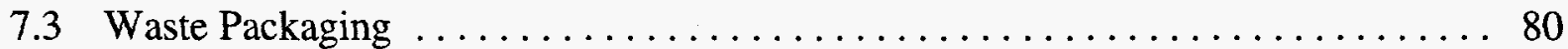

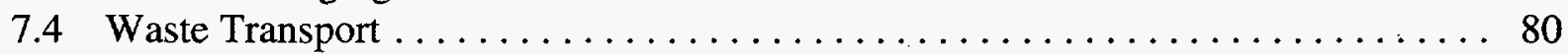

8 OCCUPATIONAL EXPOSURE TO PERSONNEL $\ldots \ldots \ldots \ldots \ldots \ldots \ldots \ldots \ldots 2$

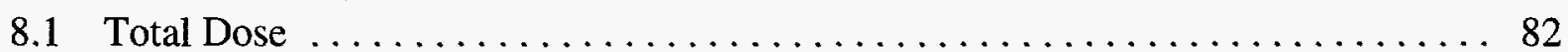

8.2 Americium Uptake.$\ldots \ldots \ldots \ldots \ldots \ldots \ldots \ldots \ldots \ldots \ldots \ldots \ldots \ldots \ldots \ldots \ldots$

9 FINAL FACILITY CONDITION $\ldots \ldots \ldots \ldots \ldots \ldots \ldots \ldots \ldots \ldots \ldots \ldots$

10 CONCLUSIONS, RECOMMENDATIONS, AND LESSONS LEARNED . . . . . . 87

10.1 General Problems Encountered and Lessons Learned . . . . . . . . . . . . . 87

10.1.1 Sling Failure during Core Assembly Lift $\ldots \ldots \ldots \ldots \ldots \ldots \ldots . \ldots 7$

10.1.2 Inability to Strike and Maintain an Arc Underwater . . . . . . . . . 87

10.1.3 Electric Shock during Underwater Plasma Arc Use ............. 88

10.1.4 Near Miss of Plasma Arc Operator Falling into the Fuel Pool . . . . . . . . 88 88

10.1.5 Smoldering Wood in Bioshield $\ldots \ldots \ldots \ldots \ldots \ldots \ldots \ldots \ldots \ldots$

10.1.6 BROKK Machine Contaminated . ................... 89

10.1.7 Cleanout and Decontamination of the Fuel Pool More Difficult than Expected ................................. 89

10.2 Recommended Approaches to Waste Packaging ................ 89

10.2.1 High Density Waste Bins for Metal and Bioshield Concrete ......... 90

10.2.2 Compactible Trash to Fill Voids in All Bins ............... 90 


\section{CONTENTS (Cont.)}

10.2.3 Hoods to Allow Trash Placement with HEPA

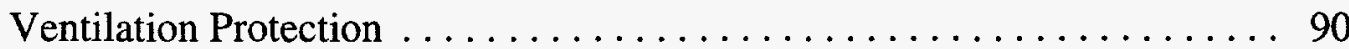

10.2.4 Hardware Baskets for Easy Handling and Rapid Draining . . . . . . . . 90

10.2.5 Shield with Remotely Operated Winches for Control Rods, Hardware Baskets, and 55 Gallon Drums .............. 90

10.2.6 Special Liners for Core Support Plate . . . . . . . . . . . . . . 90

10.3 Lessons Learned Pertaining to $\mathrm{Am}^{241}$ Unexpected Uptake $\ldots \ldots \ldots \ldots \ldots . \ldots 1$

10.3.1 Prevention and Early Detection . . . . . . . . . . . . . . . . . . 91

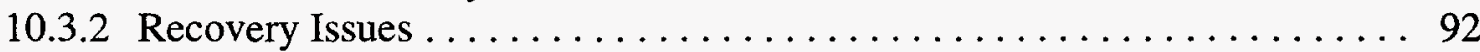

10.3.3 Management Issues $\ldots \ldots \ldots \ldots \ldots \ldots \ldots \ldots \ldots \ldots \ldots \ldots . \ldots 9 . \ldots \ldots$

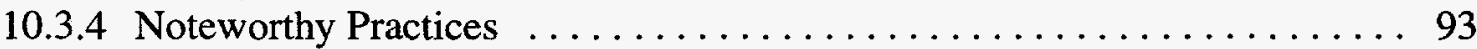

10.4 D\&D Lessons Learned . . . . . . . . . . . . . . . . . . . . . . . 94

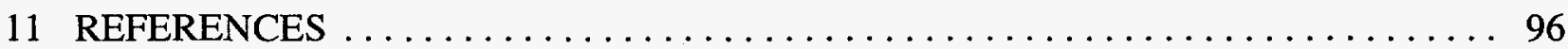

APPENDIX A: Waste Shipments $1986-1995$......................... 99

APPENDIX B: Supplemental Correspondence Concerning the Status

of EBWR at Transfer from EM-40 to EM-30 .............. 108

\section{TABLES}

1 Comparisons of the Three Cutting Methods Used for Size Reducing the EBWR Reactor Vessel ..................................... 50

2 EBWR D\&D Project Metal Cutting Methods $\ldots \ldots \ldots \ldots \ldots \ldots \ldots \ldots \ldots \ldots$

3 Final Survey Instrumentation $\ldots \ldots \ldots \ldots \ldots \ldots \ldots \ldots \ldots \ldots \ldots \ldots \ldots \ldots \ldots \ldots \ldots \ldots \ldots$

4 EBWR D\&D Project Radioactive Waste Shipments from 1986 to $1991 \ldots \ldots \ldots \ldots$. . . 78

5 Summary of Highest Radiological Levels Associated with Packaged Low Level Waste During $1994-1996$. . . . . . . . . . . . . . . . . . . . . 78

6 Estimated Total Radiation Dose Equivalent Incurred during the EBWR D\&D Project . . . . . . . . . . . . . . . . . . . . . . . 83

$7 \quad$ Analytical Results for Urine Samples $\ldots \ldots \ldots \ldots \ldots \ldots \ldots \ldots \ldots \ldots \ldots \ldots \ldots \ldots$ 


\section{FIGURES}

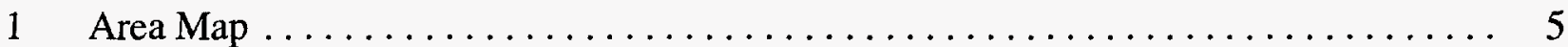

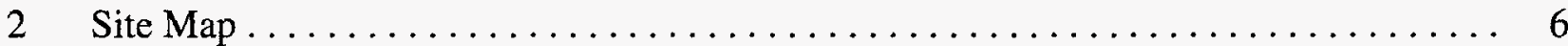

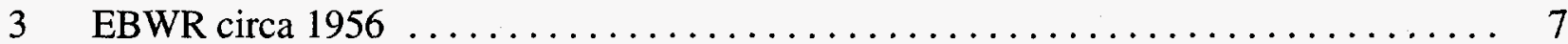

4 Outside View of EBWR Building during Construction $\ldots \ldots \ldots \ldots \ldots \ldots \ldots, 8$

$5 \quad$ EBWR Foam Glass Exterior during Installation $\ldots \ldots \ldots \ldots \ldots \ldots \ldots \ldots \ldots$

6 EBWR Reactor Vessel Prior to Installation $\ldots \ldots \ldots \ldots \ldots \ldots \ldots \ldots \ldots \ldots \ldots$

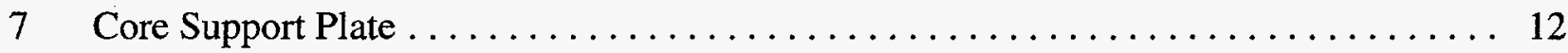

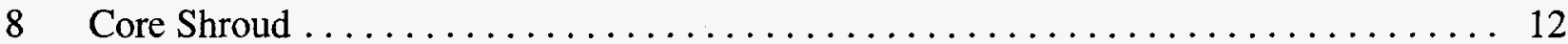

9 EBWR Project Organization through DOE to ANL-E $\ldots \ldots \ldots \ldots \ldots \ldots \ldots \ldots$

10 Responsibility Structure for $D \& D$ Projects $\ldots \ldots \ldots \ldots \ldots \ldots \ldots \ldots \ldots \ldots \ldots \ldots$

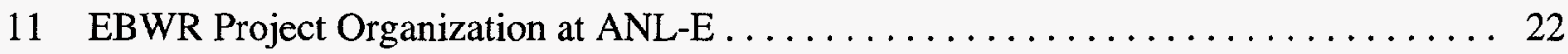

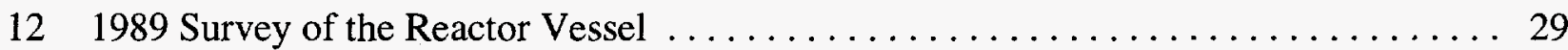

13 EBWR D\&D Project, Phase I - General Facility Preparations $\ldots \ldots \ldots \ldots \ldots \ldots$

14 EBWR D\&D Project, Phase II - EBWR Systems D\&D ................ 35

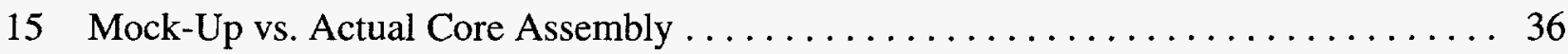

16 EBWR D\&D Project, Phase III - Reactor Vessel D\&D . . . . . . . . . . . . . 38

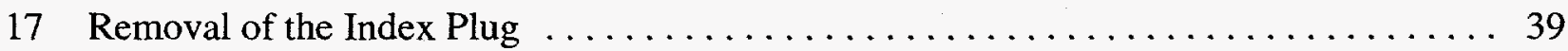

18 Removal of the Core Assembly from the Reactor Vessel to the Fuel Pool . . . . . . . . 40

19 Removal and Transfer of a Section of the Reactor Thermal Shield $\ldots \ldots \ldots \ldots \ldots .41$

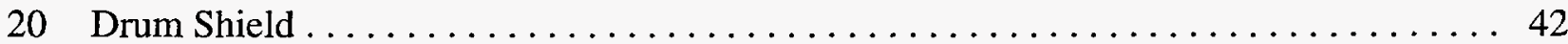

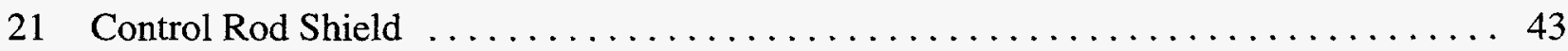

22 Items in Fuel Pool to be Size Reduced $\ldots \ldots \ldots \ldots \ldots \ldots \ldots \ldots \ldots \ldots$ 

The following is a list of acronyms, initialisms, and abbreviations (including chemicals and units of measurement) used in this document.

\section{ACRONYMS, INITIALISMS, AND ABBREVIATIONS}

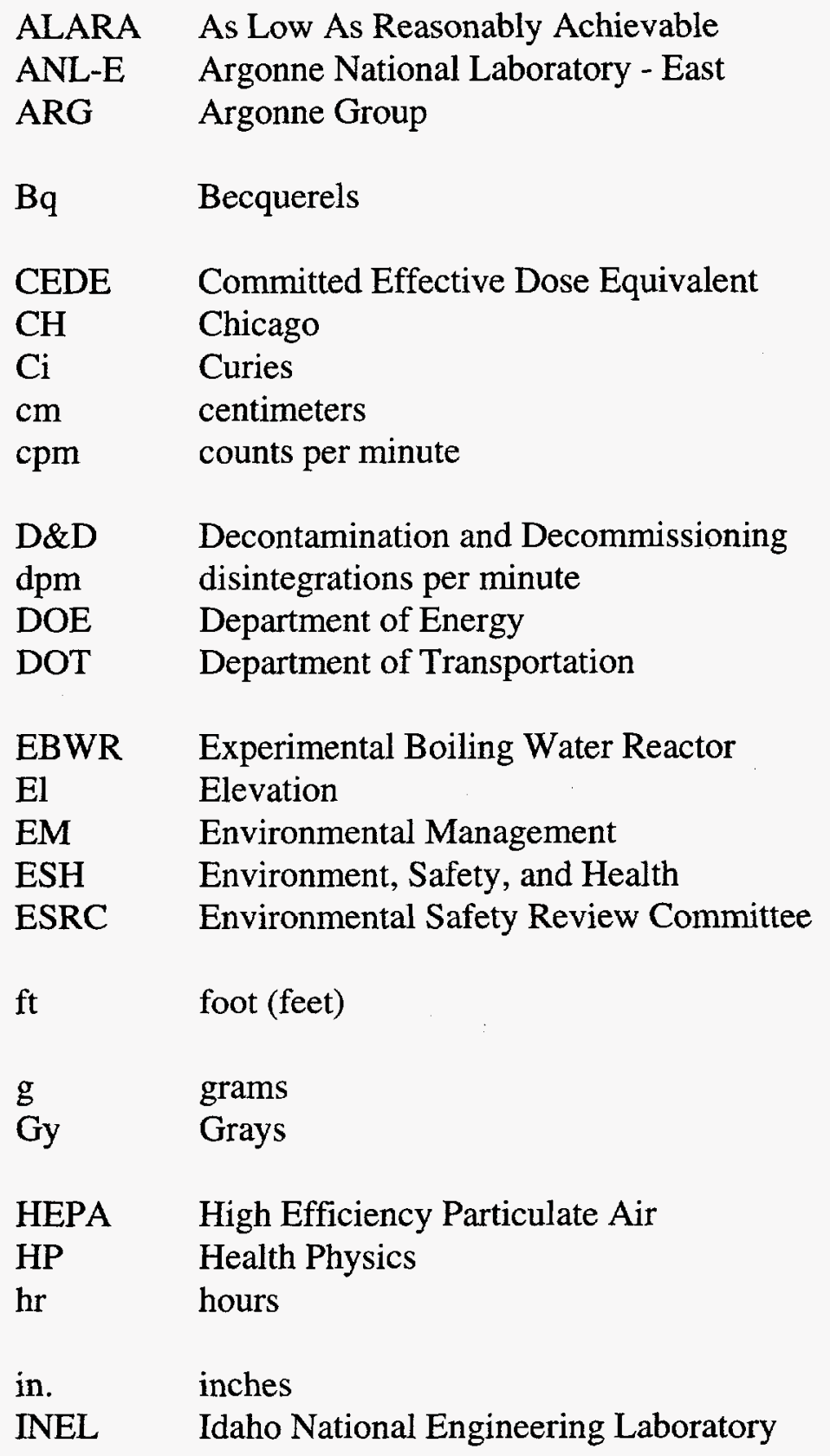




\begin{tabular}{|c|c|}
\hline $\mathrm{k}$ & kilo \\
\hline $\mathrm{kW}$ & kilowatts \\
\hline $\mathrm{kWt}$ & kilowatts thermal \\
\hline lb & pounds \\
\hline LSA & Low Specific Activity \\
\hline $\mathrm{m}$ & meters \\
\hline $\mathrm{m}$ & milli \\
\hline MDA & Minimum Detectable Activity \\
\hline $\min$ & minutes \\
\hline$\mu$ & micro \\
\hline N/A & Not Applicable \\
\hline NIOSH & National Institute for Occupational Safety and Health \\
\hline No. & Number \\
\hline ORR & Operational Readiness Review \\
\hline OSHA & Occupational Safety and Health Administration \\
\hline QA & Quality Assurance \\
\hline QAR & Quality Assurance Representative \\
\hline $\mathbf{R}$ & Roengtens \\
\hline RWP & Radiological Work Permit \\
\hline sq. in. & square inches \\
\hline $\mathrm{Sv}$ & Sieverts \\
\hline TD & Technology Development \\
\hline WMO & Waste Management Operations \\
\hline WTS & Wachs Technical Services \\
\hline
\end{tabular}




\title{
DECONTAMINATION AND DECOMMISSIONING OF THE EXPERIMENTAL BOILING WATER REACTOR (EBWR): PROJECT FINAL REPORT, ARGONNE NATIONAL LABORATORY
}

by

\author{
C.R. Fellhauer, L.E. Boing, and J. Aldana
}

\section{SUMMARY}

The Final Report for the Decontamination and Decommissioning (D\&D) of the Argonne National Laboratory - East (ANL-E) Experimental Boiling Water Reactor (EBWR) facility contains the descriptions and evaluations of the activities and the results of the EBWR D\&D project. It provides the following information:

- An overall description of the ANL-E site and EBWR facility.

- The history of the EBWR facility.

- A description of the D\&D activities conducted during the EBWR project.

- A summary of the final status of the facility, including the final and confirmation surveys.

- A summary of the final cost, schedule, and personnel exposure associated with the project, including a summary of the total waste generated.

This project report covers the entire EBWR D\&D project, from the initiation of Phase I activities to final project closeout. After the confirmation survey, the EBWR facility was released as a "Radiologically Controlled Area," noting residual elevated activity remains in inaccessible areas. However, exposure levels in accessible areas are at background levels. Personnel working in accessible areas do not need Radiation Work Permits, radiation monitors, or other radiological controls. Planned use for the containment structure is as an interim transuranic waste storage facility (after conversion).

Argonne National Laboratory has decontaminated and decommissioned all accessible areas at the EBWR Facility to radiological background levels. The project consisted of decontaminating and/or packaging as radioactive waste, the reactor vessel and internals, contaminated piping systems, miscellaneous tanks, pumps, and associated equipment. D\&D work involved dismantling process 
equipment and associated plumbing, ductwork, drain lines, etc.; size reduction of reactor vessel internals; and packaging and properly documenting all radioactive waste, including shipment and disposal. A thorough survey of the facility was made after the removal of activated and contaminated material. Nonradioactive waste of little scrap value was disposed of in the ANL-E landfill. Project plans divided the D\&D project work into Phases I through IV. ANL-E personnel completed Phases I and II. A subcontractor performed Phases III and IV under ANL-E management. The subcontractor conducted the final survey and ANL-E performed the verification survey.

The total project duration was 118 months. Phase I was initiated in April 1986 and the final report was issued in February 1996. The total exposure to project personnel was 208.7 person-mSv (20.87 person-rem), with no individual exceeding the EBWR D\&D project limit of $15 \mathrm{mSv}$ (1.5 rem). The total cost of the EBWR D\&D project, including labor, management, and waste disposal, was $\$ 19,586,000$. A total of $360,205 \mathrm{~kg}(792,452 \mathrm{lb})$ of radioactive waste, including liners, was packaged for off-site disposal at a low level radioactive waste repository. The total activity of the waste was $24,789 \mathrm{G} \mathrm{Bq}(670.23 \mathrm{Ci})$. Additionally, $26,829 \mathrm{~kg}(59,023 \mathrm{lb})$ of mixed waste, including liners, with a total activity of 3,171 MB (85.7 MCi) was packaged for disposal. In January 1996, the EBWR facility was formally decommissioned and transferred from EM-40 to EM-30. 


\section{PROJECT OBJECTIVE}

The EBWR D\&D project was directed toward the following objectives:

- Removal of radioactive materials associated with the EBWR facility from the ANL-E site.

- Decontamination of the EBWR Facility to unrestricted use levels.

- The cleanup of the EBWR containment building and its formal decommissioning.

The primary areas of concern associated with the D\&D of the EBWR facility included the induced radioactivity of the reactor internals and the reactor vessel itself. A secondary concern was the lesser level of radioactivity in the reactor systems, reactor components, and bioshield concrete. The primary radionuclide of concern was $\mathrm{Co}-60$, with $\mathrm{Fe}-55$, Ni-63 and trace quantities of miscellaneous radionuclides present in the facility. Radiation levels on the stainless steel inner surface of the reactor vessel was $6 \mathrm{mSv} / \mathrm{hr}(600 \mathrm{mrem} / \mathrm{hr})$ or less, and the reactor internals had a maximum dose rate of $2 \mathrm{~Sv} / \mathrm{hr}(200 \mathrm{rem} / \mathrm{hr})$. The Department of Energy (DOE) Order 5480.2A establishes the maximum whole body dosage allowed for occupational workers at $50 \mathrm{mSv}(5 \mathrm{rem})$ per year, while the ANL-E administrative limit is $10 \mathrm{mSv}$ (1 rem) per year. In the dry lay-up condition, the EBWR facility presented a significant radiological safety concern due to the potential for inadvertent exposure to personnel. The primary objective of the EBWR D\&D project was to eliminate this safety concern. Additional objectives included the reuse of equipment and materials in the facility, and the reuse of the facility and land for other purposes. 


\section{FACILITY DESCRIPTION AND HISTORY}

\subsection{SITE CHARACTERISTICS}

The ANL-East site is approximately 22 miles southwest of downtown Chicago and 25 miles west of Lake Michigan at the nearest point. The EBWR facility is in the 300 West Area of the site. Access to the site is provided by State Highway 83, Westgate Road, Lemont Road, Northgate Road and Cass Avenue, all having access with Interstate Highway 55 (Figure 1). The area south and west is primarily rural, with the more heavily populated areas to the north and east. The 8.26 square kilometer $\left(\mathrm{km}^{2}\right)$ (2040 acre) Waterfall Glen Forest Preserve of the DuPage County Forest Preserve District, surrounds the ANL-E site. The Des Plaines River, the Chicago Sanitary and Ship Canal and the Illinois Waterway (Illinois and Michigan Canal) are all located about one mile beyond the southern boundary of the Laboratory site. The Laboratory occupies a $5.16 \mathrm{~km}^{2}(1,275$-acre) reservation in DuPage County, Illinois, with $0.81 \mathrm{~km}^{2}$ (200 acres) of operational facilities and the remaining $4.35 \mathrm{~km}^{2}$ (1,075 acres) devoted to landscaping and forest (Figure 2).

Approximately 4,000 employees work at the ANL-East site. The EBWR shell containment building was unoccupied during D\&D except for the conversion project work force. Most of the work described in this report took place inside the facility. D\&D project staff offices and contractor personnel were housed in temporary trailer offices situated near EBWR.

\subsection{FACILITY BACKGROUND}

The EBWR was built as a test reactor to show the feasibility of operating an integrated power plant using a direct cycle boiling water reactor as a heat source. The reactor was designed to produce 20,000 kilowatts $(\mathrm{kW})$ of heat in the form of $4.14 \mathrm{MPa}(600 \mathrm{lb} / \mathrm{sq}$. in.) gage saturated steam fed directly to a turbo-generator producing $5,000 \mathrm{~kW}$ of electricity. Full power operation at its design output of 20,000 kilowatts thermal (kWt) was first achieved in December 1956 (see Figure 3).

Following intermittent operation at power levels up to $61,700 \mathrm{kWt}$, the EBWR was modified to increase its power output capability to $100,000 \mathrm{kWt}$. The modifications included the addition of a reboiler plant to use $80,000 \mathrm{~kW}$ of thermal energy beyond the $20,000 \mathrm{kWt}$ used by the turbo-generator. In November 1962, the reactor was successfully operated at $100,000 \mathrm{kWt}$. Soon afterward the experimental program at the EBWR was completed and operation of the plant ceased temporarily. Experimental work on EBWR was completed in July 1967, and the plant was shut down permanently and placed in a dry lay-up condition. The facility was deactivated by draining all liquids from the primary, secondary, and the auxiliary systems and flushing them thoroughly. All valves 


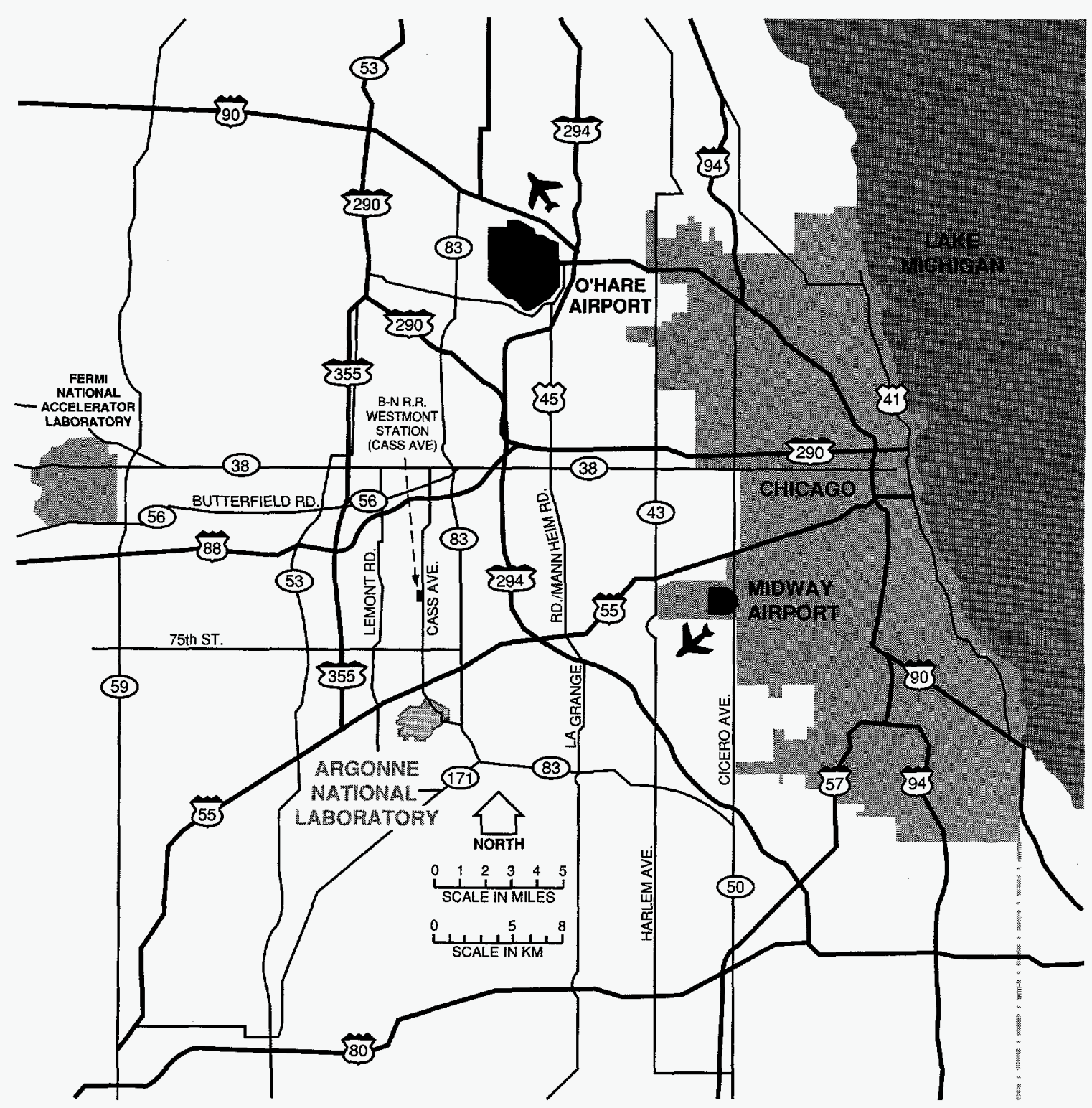

FIGURE 1 Area Map

were left in the open position. In addition, certain flanges were removed, and holes were drilled at system low points to ensure complete draining. Nuclear fuel was removed from the reactor and shipped to the DOE-Savannah River Plant for reprocessing. The fuel storage pool was drained, flushed, and surfaces decontaminated. Electrical switch gear (except building lights), the crane, and the elevator, was taken out of service. Additionally, power and control cables leaving the containment shell were cut. Several outbuildings were either demolished or converted for reuse before 1980. Surveillance and maintenance of the facility continued throughout the dry lay-up period. The facility was maintained in a safe storage mode until the D\&D project was initiated in the first quarter of fiscal year 1986. 


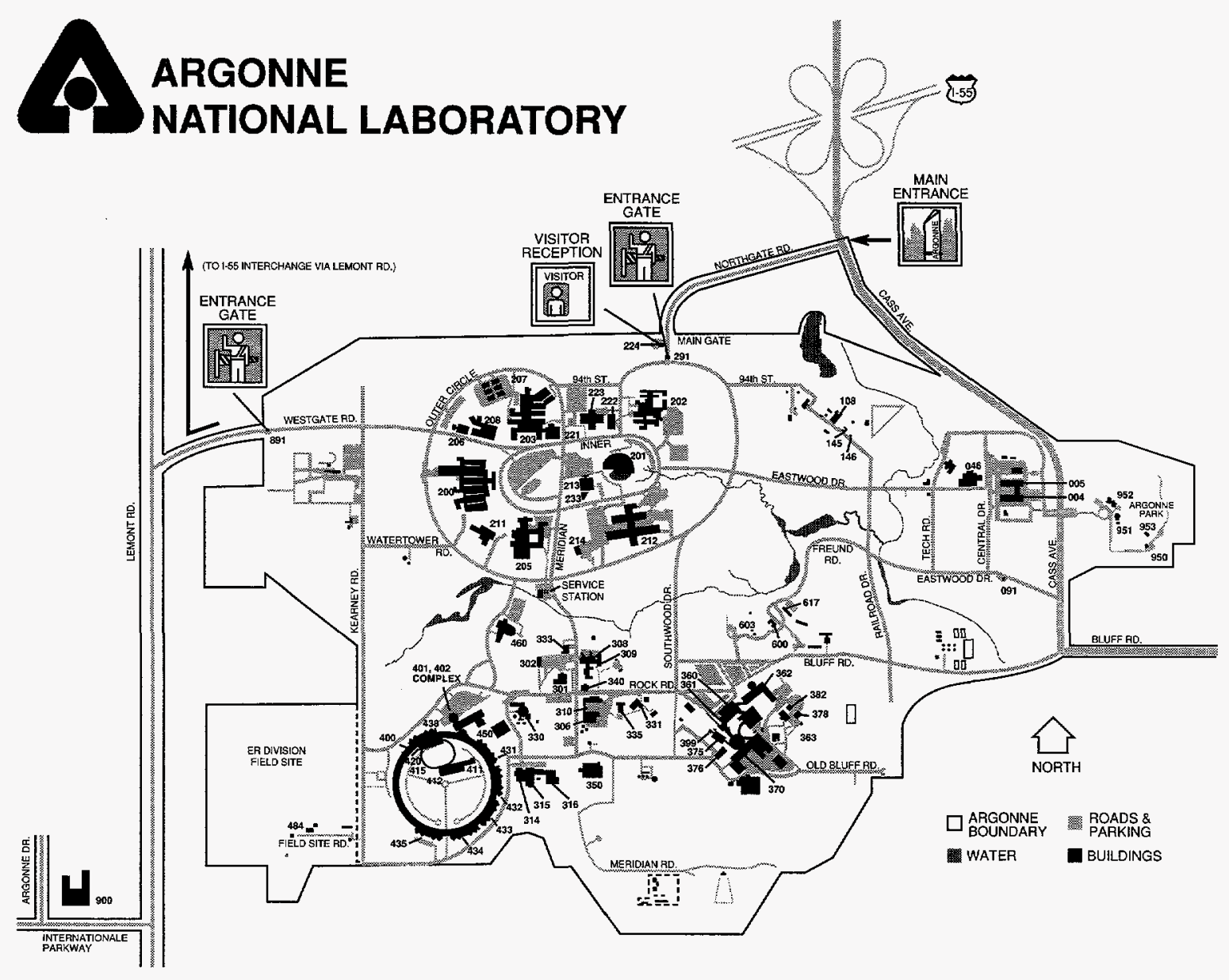

FIGURE 2 Site Map

\subsection{FACILITY DESCRIPTION}

\subsubsection{Facility Design}

The containment building is a circular, domed structure made of steel plates welded

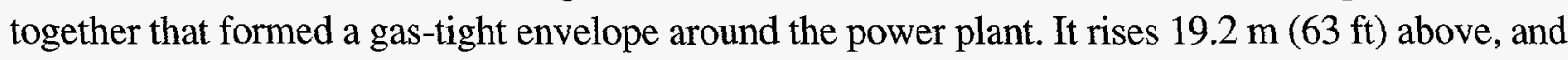
extends $17.1 \mathrm{~m}(56 \mathrm{ft})$ below ground level, and has an inside diameter of approximately $24.4 \mathrm{~m}$ $(80 \mathrm{ft}$ ) (Figure 4). Below ground level, the steel shell is 1.6 centimeters (cm) (5/8-in.) thick; above ground level it is $1 \mathrm{~cm}(3 / 8$-in.) thick. The interior of the steel shell is lined with a $0.61 \mathrm{~m}(2-\mathrm{ft})$ thickness of reinforced concrete below the main floor level. Above the main floor, to a height of $7.6 \mathrm{~m}(25 \mathrm{ft})$, there is a $0.3 \mathrm{~m}(1-\mathrm{ft})$ thick concrete lining. At the $7.92 \mathrm{~m}(26 \mathrm{ft})$ height a $0.3 \mathrm{~m}(1-\mathrm{ft})$ 


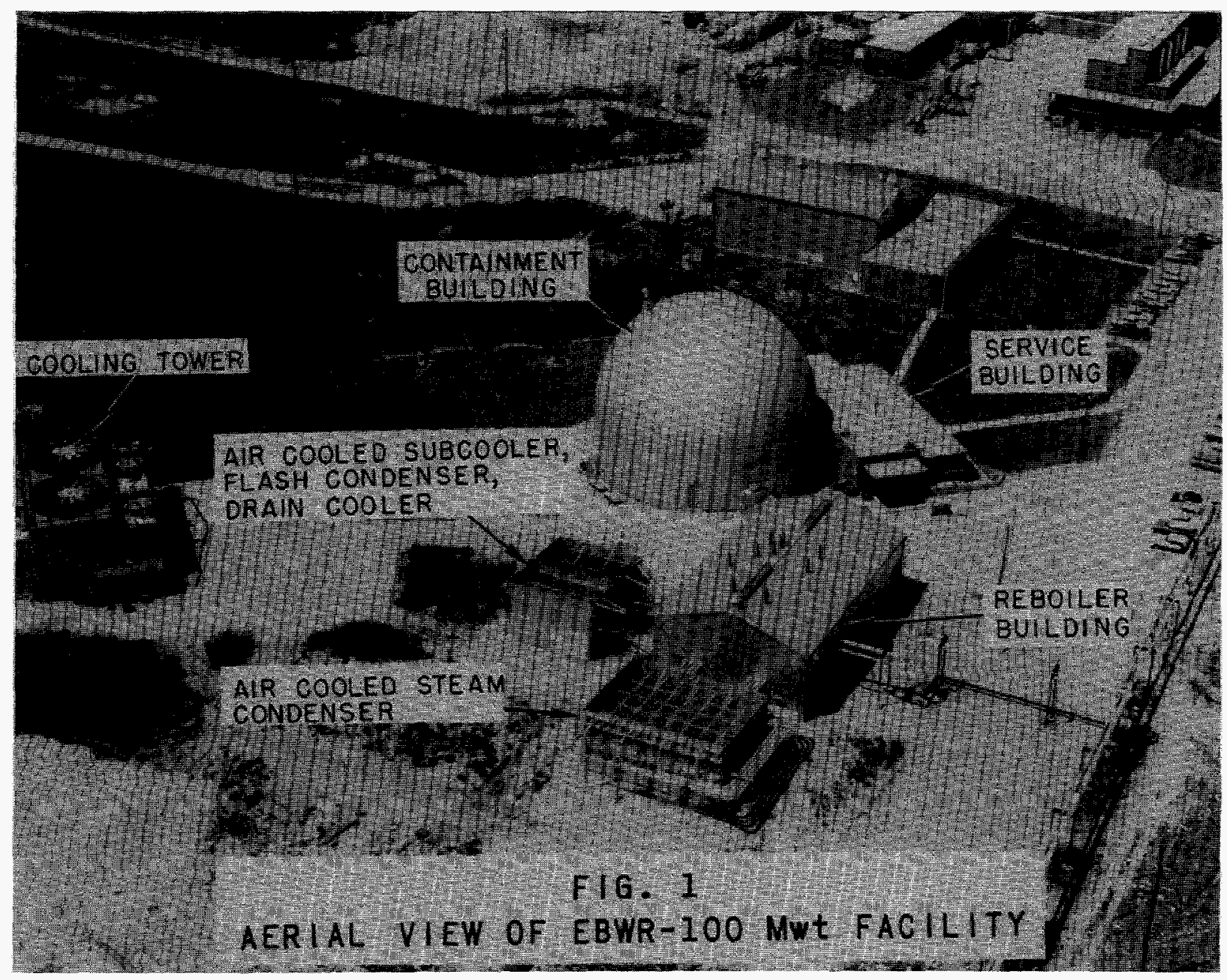

FIGURE 3 EBWR circa 1956 (ANL NEG \#202-295)

thick concrete ceiling slab faced with $1 \mathrm{~cm}(3 / 8$-in.) thick steel plate completes the concrete envelope surrounding the power plant inside the containment shell.

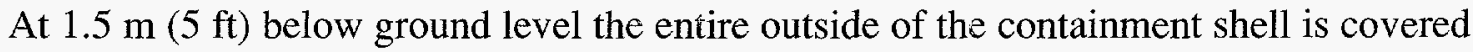
with $7.62 \mathrm{~cm}$ (3-in.) thick foam glass blocks that are impaled on metal studs welded to the shell (Figure 5). Joints between the blocks were filled with mastic during installation and a coat of mastic was then applied over the blocks followed by a layer of woven glass fabric. On the upper portion of the dome, a second coat of mastic and another layer of glass fabric was applied. A final coat of mastic was then applied over the entire insulated surface. Corrosion protection of the shell below grade was provided by applying two coats of bituminous enamel. One-inch thick insulating board was applied over the enamel and left permanently in place to protect the enamel during backfilling of the excavation. 


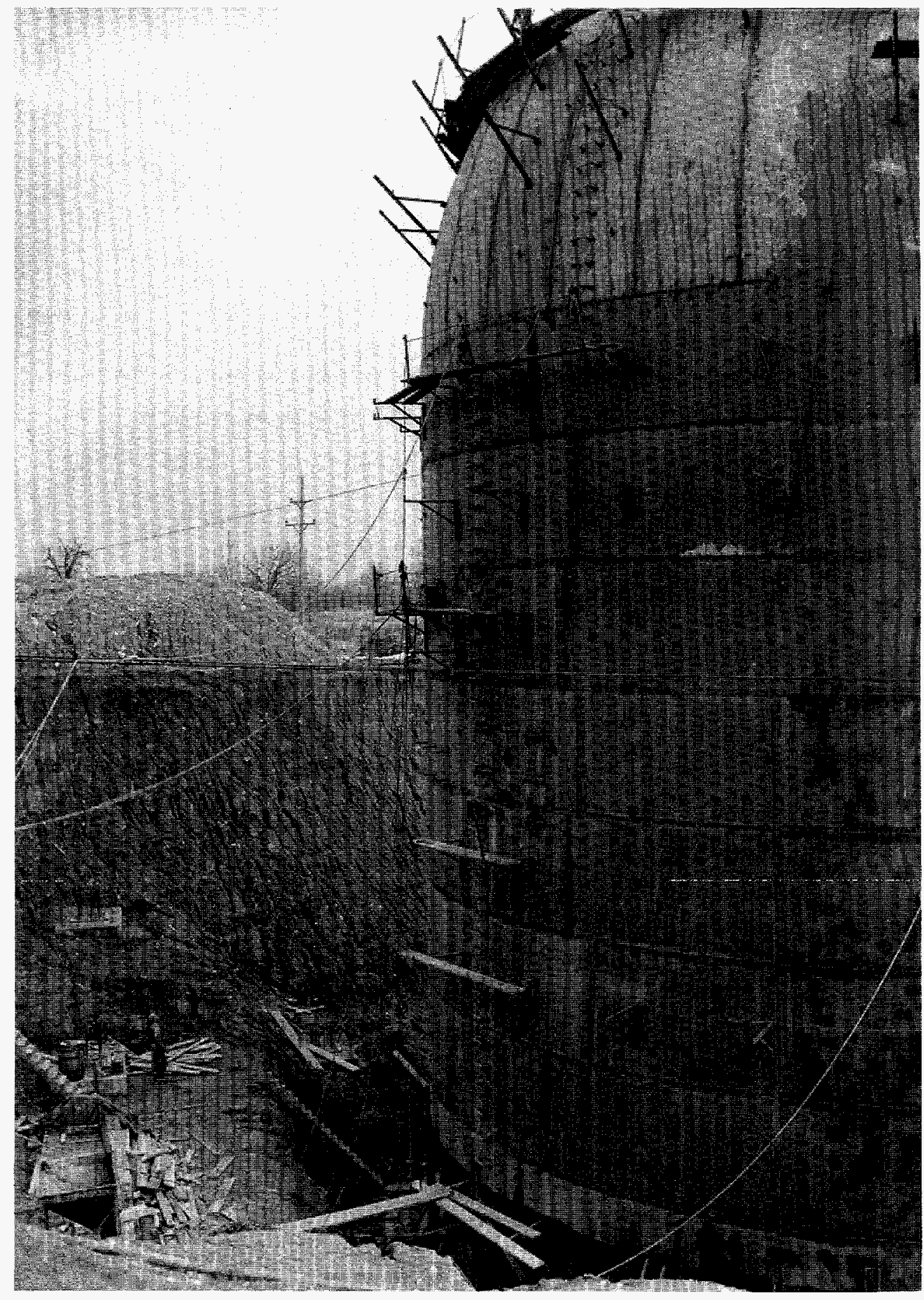

FIGURE 4 Outside View of EBWR Building during Construction (ANL NEG \#111-3411) 


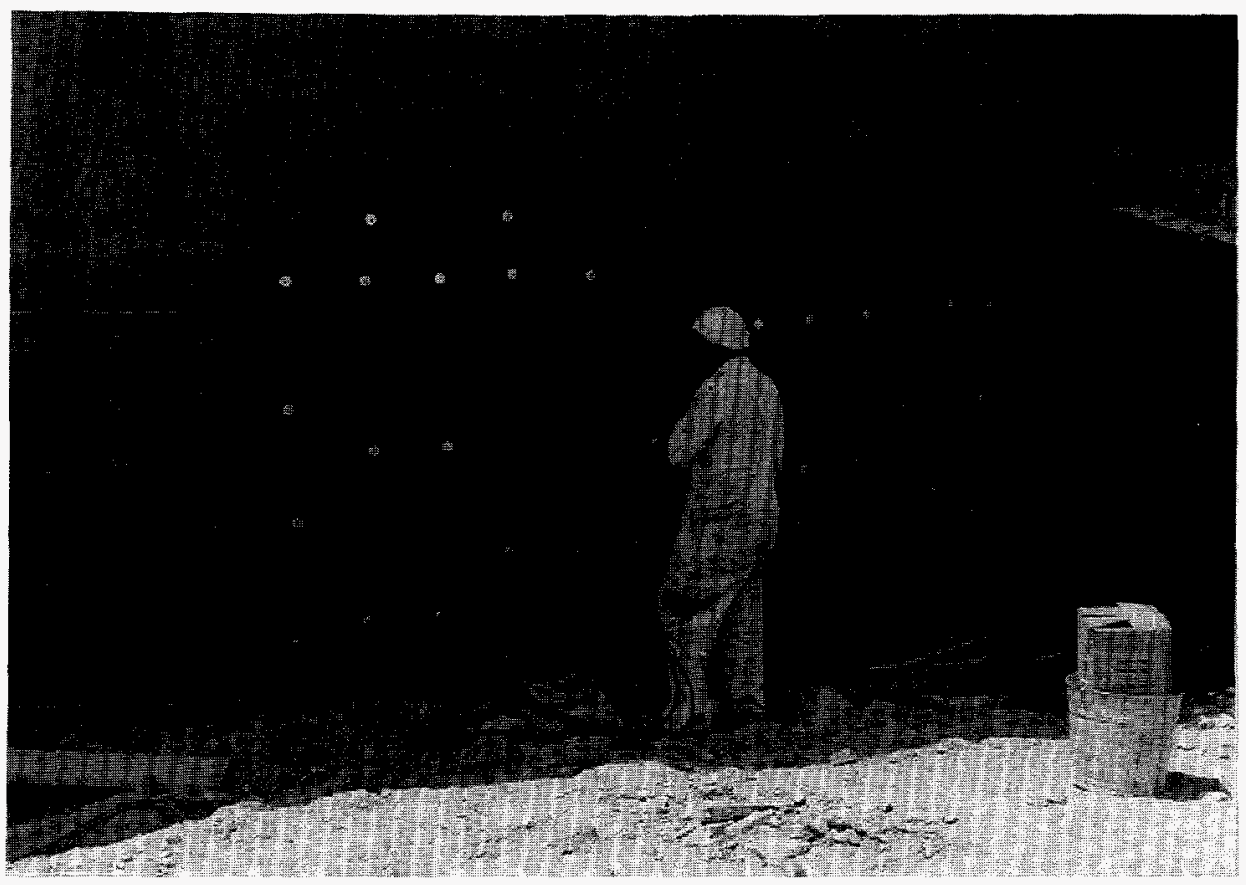

FIGURE 5 EBWR Foam Glass Exterior during Installation (ANL NEG \#111-4545)

An unusual feature of the containment building was a 56,850 liter (15,000 gal) storage tank in the top of the dome. The tank was supported by the top dome structure of $1 \mathrm{~cm}(3 / 8$-in.) thick steel plate strengthened where the tank attaches to the dome by metal reenforcing rings. The tank was designed to provide a dependable supply of water to the in-house sprinkler system in case of a major steam release within the shell. It was drained at the time of shutdown and remained empty throughout the D\&D project.

The containment building contains a main floor and three lower floors on which the power plant equipment was located. The main floor is a heavy, reinforced concrete slab designed for a uniform allowable floor loading of $69.3 \mathrm{kPa}\left(2,000 \mathrm{lb} / \mathrm{ft}^{2}\right)$. The condenser floor and the pump floor also consist of reinforced concrete slabs in the areas where the main power plant equipment was located. These lower level slabs comprise approximately one-third of the total area at each elevation and were designed for a uniform allowable floor loading of $23.9 \mathrm{kPa}\left(500 \mathrm{lb} / \mathrm{ft}^{2}\right)$. One-third of the condenser and pump floor area consists of steel grating supported on structural steel beams and stringers. The remaining one-third consists of hatchways and other uncovered areas. The steel grating was designed for a uniform allowable floor loading of $3.6 \mathrm{kPa}\left(75 \mathrm{lb} / \mathrm{ft}^{2}\right)$. Between floors, galleries floored with steel grating or steel plates provide access to various plant equipment. This flooring was also designed for a uniform allowable loading of $3.6 \mathrm{kPa}\left(75 \mathrm{lb} / \mathrm{ft}^{2}\right)$. 


\subsubsection{Reactor Pressure Vessel and Internals}

The reactor pressure vessel was contained within a shielded cell that extended from the

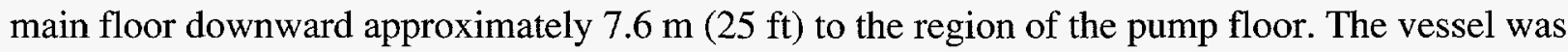
made of carbon steel, clad with stainless steel on those surfaces that were in contact with reactor water or steam (Figure 6). It was approximately $2.26 \mathrm{~m}$ (7-ft 5-in.) in outside diameter, $7.5 \mathrm{~m}$ (24-ft 8-in.) in length and had a nominal wall thickness of $6.4 \mathrm{~cm}\left(2 \frac{1}{2} \mathrm{in}\right.$.). Nine control rod drive tubes and four forced circulation inlet pipe stubs extended downward from the bottom shielding. Two $0.30 \mathrm{~m}$ (12-in.) diameter forced circulation outlet pipes also extended from the pressure vessel through the cell's bottom shield. The vessel was closed by a forged steel cover plate approximately $22.9 \mathrm{~cm}(9-$ in. $)$ thick which was retained by forty-four $6.4 \mathrm{~cm}\left(2 \frac{1}{2} \mathrm{in}\right.$.) stud bolts.

The pressure vessel contained the following items:

- Indexing shield plug

- Steam duct

- Poison spray ring

- Condensate return rings (2)

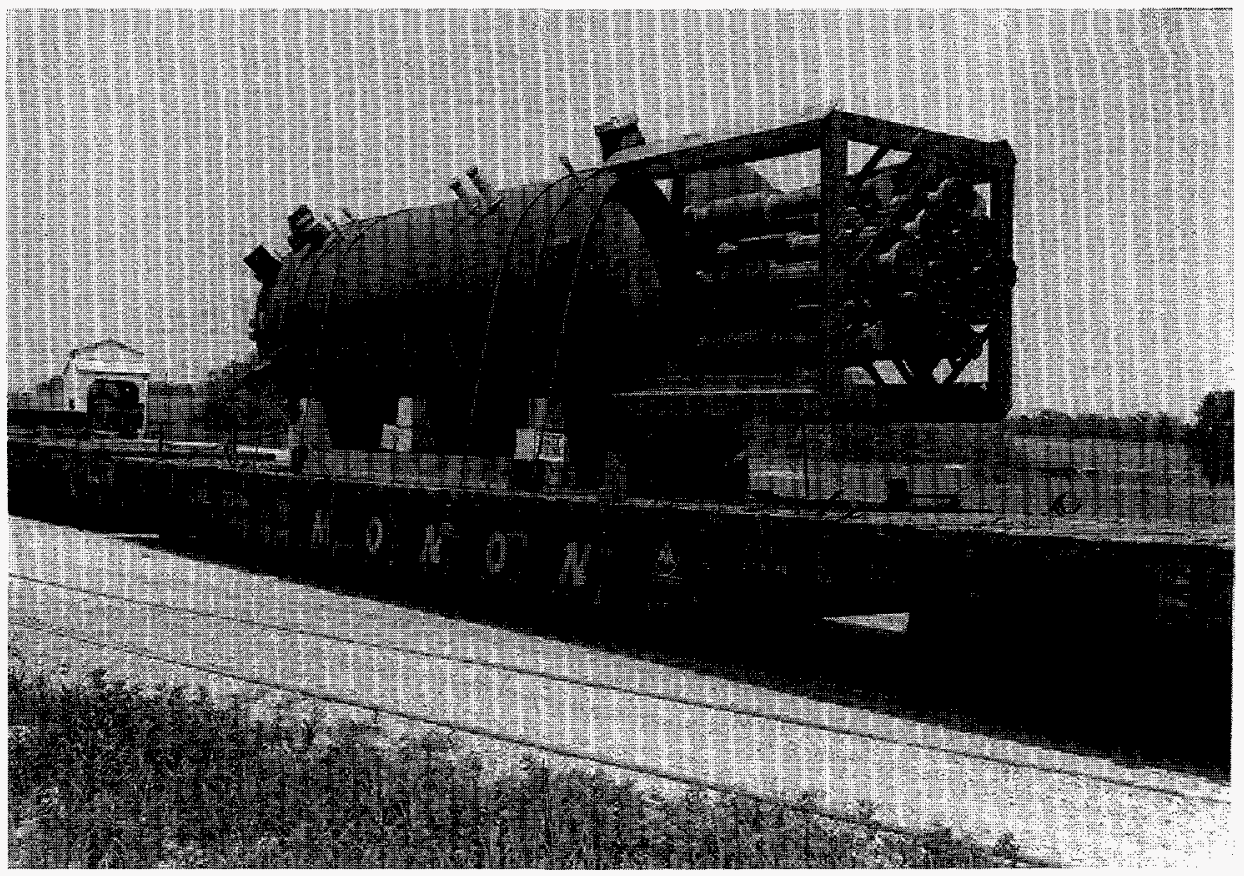

FIGURE 6 EBWR Reactor Vessel Prior to Installation (ANL NEG \#111-4144) 
- Shock shield

- Core riser

- Core support grid (Figure 7)

- Core shroud (Figure 8)

- Control rods guide shroud

- Control rods (9)

The pressure vessel and its internal structures were the most radioactive items encountered during the project.

The exterior of the pressure vessel was covered by a layer of thermal insulation consisting of $7.6 \mathrm{~cm}$ ( 3 in.) thick stainless steel wool held in place by stainless steel bands and a wire mesh. Three inches of dead air space separated the steel wool from the inner surface of the steel cylinder reactor vessel cavity liner, approximately $2.6 \mathrm{~m}(81 / 2 \mathrm{ft})$ in diameter and made of $1.9 \mathrm{~cm}(3 / 4 \mathrm{in}$.) thick plate, which was the inner boundary of the reactor cavity. Lead bricks were stacked against the outside of the cylinder to provide radiation shielding. Shield cooling coils made of copper tubing were fastened to the steel cylinder beneath the lead.

\subsubsection{Main Floor}

The containment building main floor included the following components:

- Reactor top shield tank and integral steel backup plate

- Fuel coffin and transfer carriage

- Turbine-generator and associated equipment

- High pressure boric acid tank and injection valves

- The fuel storage pool (pool surface) 


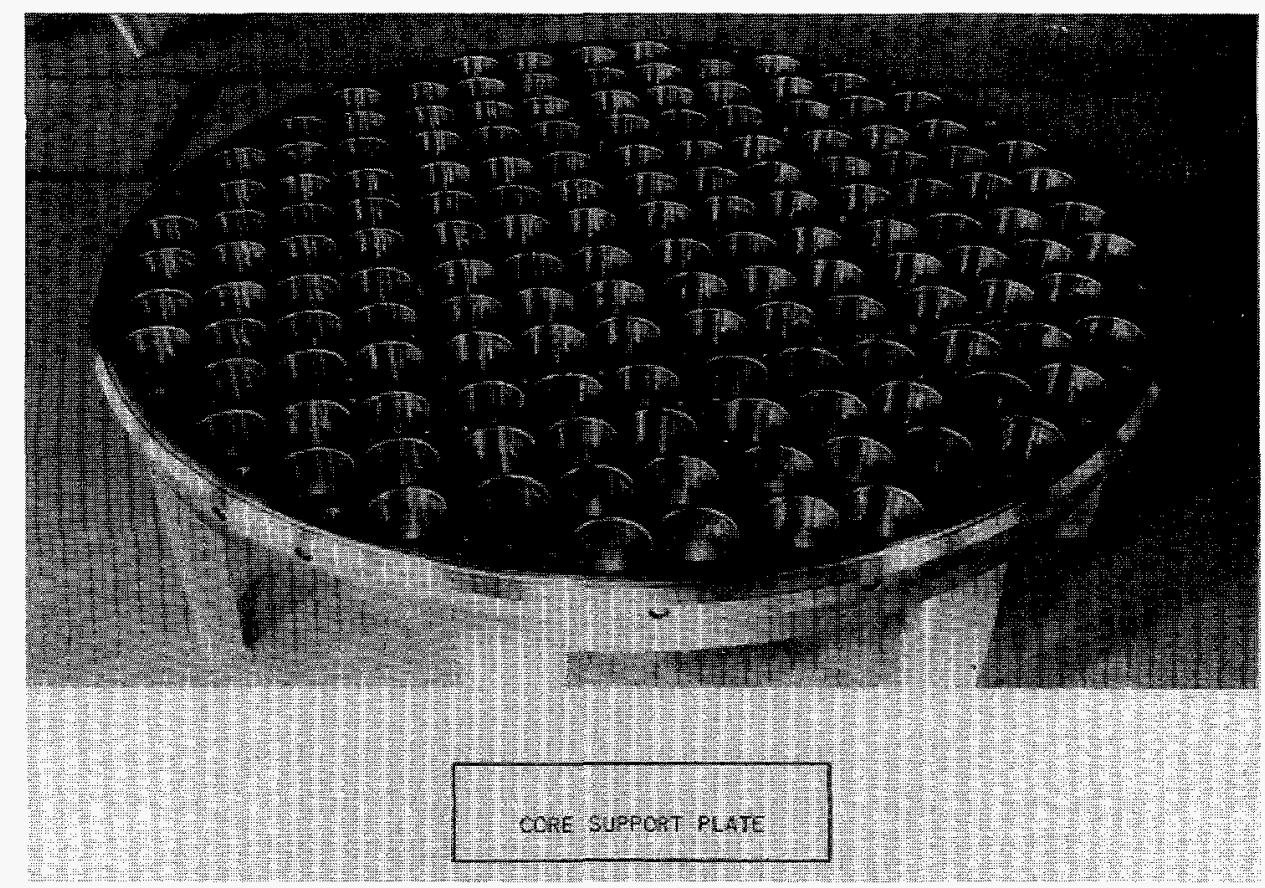

FIGURE 7 Core Support Plate (ANL NEG \#111-4407)

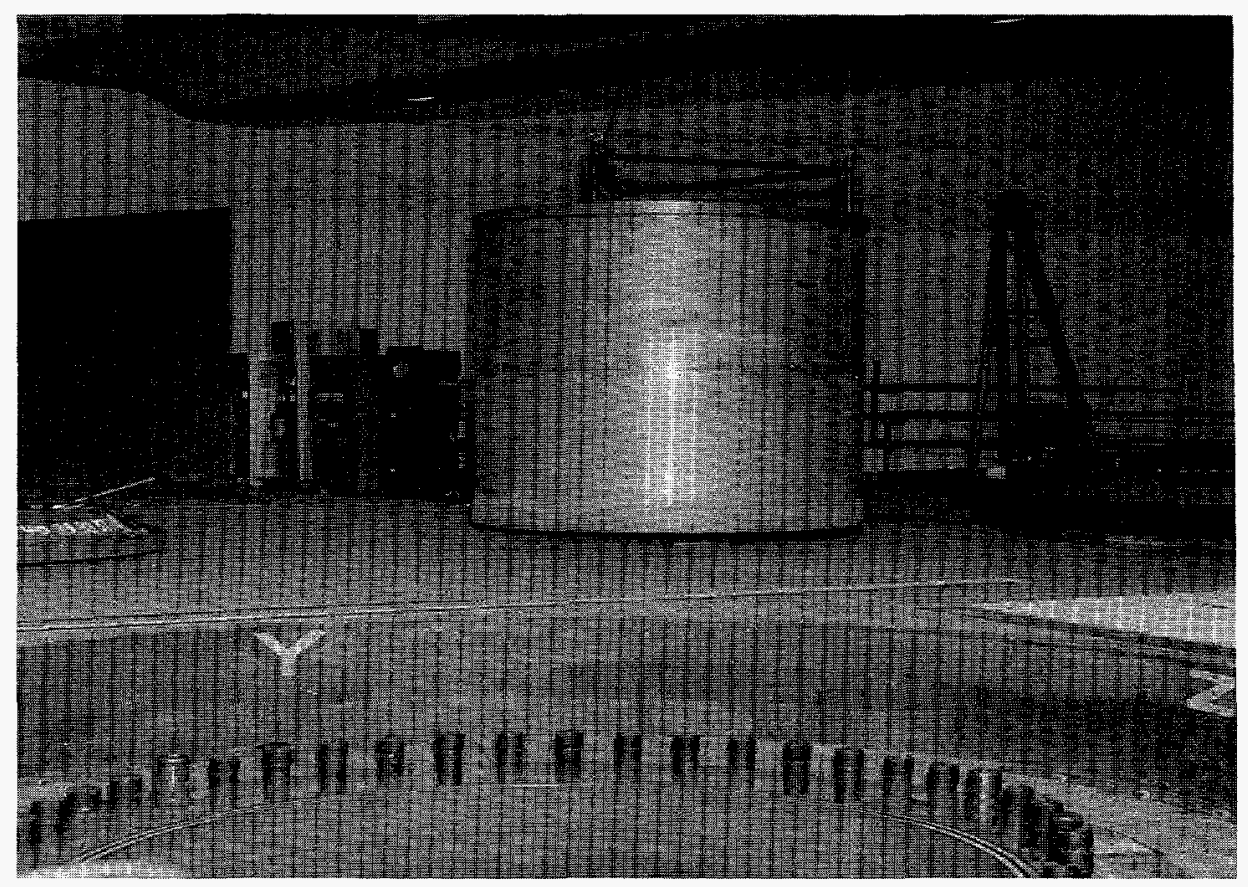

FIGURE 8 Core Shroud (ANL NEG \#111-7725) 


\subsubsection{Condenser Floor}

Plant components on the condenser floor included:

- Main condenser

- Main cooling-water circulating pumps (2)

- Main cooling-water system valves and piping

- Stream dryer/emergency cooler

- Desuperheater

- Deaerator

- Air ejectors

- Main steam system valves and piping

- Feed water Filters 1 and 2

- Instrument air compressors 1 and 2

- Electrical generator surge protection gear

- Reactor water-level column

\subsubsection{Pump Floor}

Plant components on the pump floor included:

- Start-up heater

- Feed water System subcooler

- $\quad$ Feed water pumps 1 and 2

- Feed water filters 3 and 4 
- Feed water system valves and piping

- Auxiliary cooling water pumps 1 and 2

- Fluid (vapor) recovery system

- Condenser tube-sheet vacuum/drain tank

- Recombiner system

\subsubsection{Basement Floor}

The following plant components were on the basement floor:

- Reactor water purification system

- Reactor control rod drives

- Reactor vessel blowdown system

- Reactor shield-cooling pumps and heat exchanger

- Feedwater pumps 3 and 4

- Retention tanks and pumps (2)

\subsubsection{EBWR under Dry Lay-Up Conditions}

At the initiation of the EBWR D\&D project, the EBWR facility was in dry lay-up condition. The dry lay-up was accomplished through the deactivation of systems and auxiliaries after defueling and cleanup from the EBWR Plutonium Recycle Program. The primary system was drained to the retention tanks and the reactor vessel internals and control rods were left in place. The bioshield was left in place. All piping systems were drained and flushed, all valves in the system were left in the open position, and all tanks (including the two radioactive waste retention tanks), filter vessels and heat exchangers were fully drained and left open at shutdown. The fuel storage pool was drained and flushed, and the fuel element storage rack and rack support frame was left in the pool. The pool was covered with its grid plate and a painted plywood cover installed. Radiological surveillance and maintenance was initiated at this time. 
During the dry lay-up condition the containment shell was closed with the freight door bolted. The emergency escape hatch was locked, and the outlet air valve was left opened to allow air flow into the building. The personnel air lock was opened with a wire gate added and locked, and all electrical switch gear in the containment building, except lighting, was deactivated.

The service building was converted for office space, and the control room area was disassembled and converted to classroom space. These facilities were not part of the EBWR D\&D project. To gain useful service of valuable and available laboratory space, the cooling towers were demolished in 1979 and the reboiler building converted for other use by Plant Facilities and Services personnel.

\subsection{OVERVIEW OF THE EBWR D\&D PROJECT}

The EBWR D\&D project began in 1986 with general facility preparations (Phase I D\&D). This work consisted of typical mobilization activities including the establishment of a project management structure and preparation for hands-on dismantling work. The remainder of Phase I was dedicated to asbestos insulation removal throughout the facility primarily from piping with limited removal of equipment insulation. Phase II of the D\&D began in 1988 and consisted of the removal of all reactor system piping, components, and associated equipment both radioactively and nonradioactively contaminated. This phase of the D\&D was completed in 1990 .

Phase III of the D\&D included the removal of reactor vessel components. D\&D subcontractor ALARON was tasked to conduct decontamination activities for this phase and followon Phase IV D\&D. Preparations for this phase involved the setup of the ventilation system and the containment tent, the refilling of the fuel storage pool, and the start of mockup training of the Reactor Vessel Complex. This portion of Phase III was completed in 1993. The remainder of Phase III was divided into Phases IIIA and IIIB. Reactor vessel closure items were removed as part of Phase IIIA. Next, items within the reactor vessel were removed, including control rods, core shroud, shock shield, and steam collector. Phase IIIB included the removal of the reactor vessel, which was sectioned for disposal. Phase III (including both Phases IIIA and IIIB) of the project was completed in June 1995.

Phase IV D\&D involved activities associated with the removal and disassembly of the activated biological shield. Components of the biological shield, including concrete and lead bricks, were removed and decontaminated for salvage or disposed of accordingly. Remaining radioactivity that could not be removed was sealed in place so that all accessible areas in the EBWR shell were at background levels of radioactivity. Phase IV also included the completion of any final decontamination activities. Miscellaneous areas with activated or contaminated material were removed or decontaminated. This phase was completed in November 1995. Project closeout requirements included completion of the final surveys, project reports, and other miscellaneous 
documentation. ALARON conducted a $\mathrm{f}$ accessible areas of the EBWR facility wet safety, and Health (ESH) Health Physic ALARON's results. This Project Repor concludes the EBWR D\&D project.

Each of the above phases of th release survey to confirm that residual activity in the low unrestricted release limits. ANL-E Environment, P) group performed a verification survey to confirm marizes the EBWR D\&D activities and results, and sct are described in detail in Section 5 of this report. 


\section{D\&D PROJECT ENGINEERING AND PLANNING}

The EBWR D\&D project consisted of four phases:

- Phase I: General Facility Preparations

- $\quad$ Phase II: EBWR Systems D\&D

- Phase III: Mobilization

- Training/Mock-Up Practice

- Support System Installation

- Phase IIIA: Reactor Vessel Internals

- Phase IIIB: Reactor Vessel

- Phase IV: Biological Shield

- Project Closeout

Preliminary engineering included the development of a decommissioning plan and a cost estimate for the EBWR D\&D project. The decommissioning plan provided a prescribed methodology for performance of EBWR D\&D project activities. The plan provided an overview of the project, projected dismantling sequences, projected schedule, anticipated health and safety considerations, and a preliminary environmental analysis. The plan provided recommendations for special equipment and supplies, and showed the anticipated job breakdown per task. The decommissioning plan was revised during the project to provide updated current and accurate information.

The cost estimate gave an estimate for the total cost of the project based on projected activities. The cost estimate includes the derivation of the anticipated costs required to complete Phase IIIA, Phase IIIB, and Phase IV decontamination activities. Included within this estimate were the costs for removal and disposal of the reactor internals, pressure vessel, fuel pool filtration system, retention tanks and piping, and containment high efficiency particulate air (HEPA) filter system. The costs to drain and decontaminate the fuel pool and to move the fuel pool gantry crane to another building at ANL-E were also included. The cost estimate included estimations on the duration, manpower requirements, waste type and waste volume for each work activity. The associated costs of labor and waste disposal were also calculated, while costs not directly associated with individual work activities such as engineering planning were calculated as undistributed costs. 
Phase III was divided into Phase IIIA and Phase IIIB to distinguish between the removal and decontamination/disposal of reactor internals and the removal of the reactor vessel. Additionally, Phase III had a training/mock-up practice period associated with it where workers made trial runs removing mock control rods and placing them in the pool. The completion of Phase IV signaled the end of the EBWR D\&D project. Therefore, Phase IV was associated with the project closeout period. These phases are described in detail below.

\subsection{PROJECT ORGANIZATION}

The EBWR D\&D project had a specific management structure in which administrative, programmatic, and technical responsibilities were delineated, including management controls and reporting systems. The various organizations involved in this project and their responsibilities are described in this subsection.

The overall ultimate responsibility for the accomplishment of the EBWR D\&D was with the Secretary of the DOE. This responsibility passed through the Office of the Assistant Secretary to the Office of Environmental Restoration and Waste Management, the Office of Environmental Restoration, and the Office of Northwest Area Programs. The DOE Chicago Operations Office was designated the DOE Argonne Group (DOE-ARG) and had overall responsibility for the administrative, programmatic, contractual, technical, and fiscal aspects of the project. DOE-ARG monitored the EBWR D\&D project. Figure 9 shows the project organization through DOE to ANL-E.

\subsection{PROJECT MANAGEMENT}

Argonne National Laboratory was assigned the lead role for the actual decommissioning of EBWR. The Laboratory directed, managed and controlled all phases of the work. The project manager was responsible for managing the day to day operations at the site including the following tasks:

- Preparing the project schedule and project and budget and cost plans

- Preparing a quality assurance (QA) plan

- Obtaining and directing the project work force

- Monitoring and documenting the progress of the project and exercising cost control 


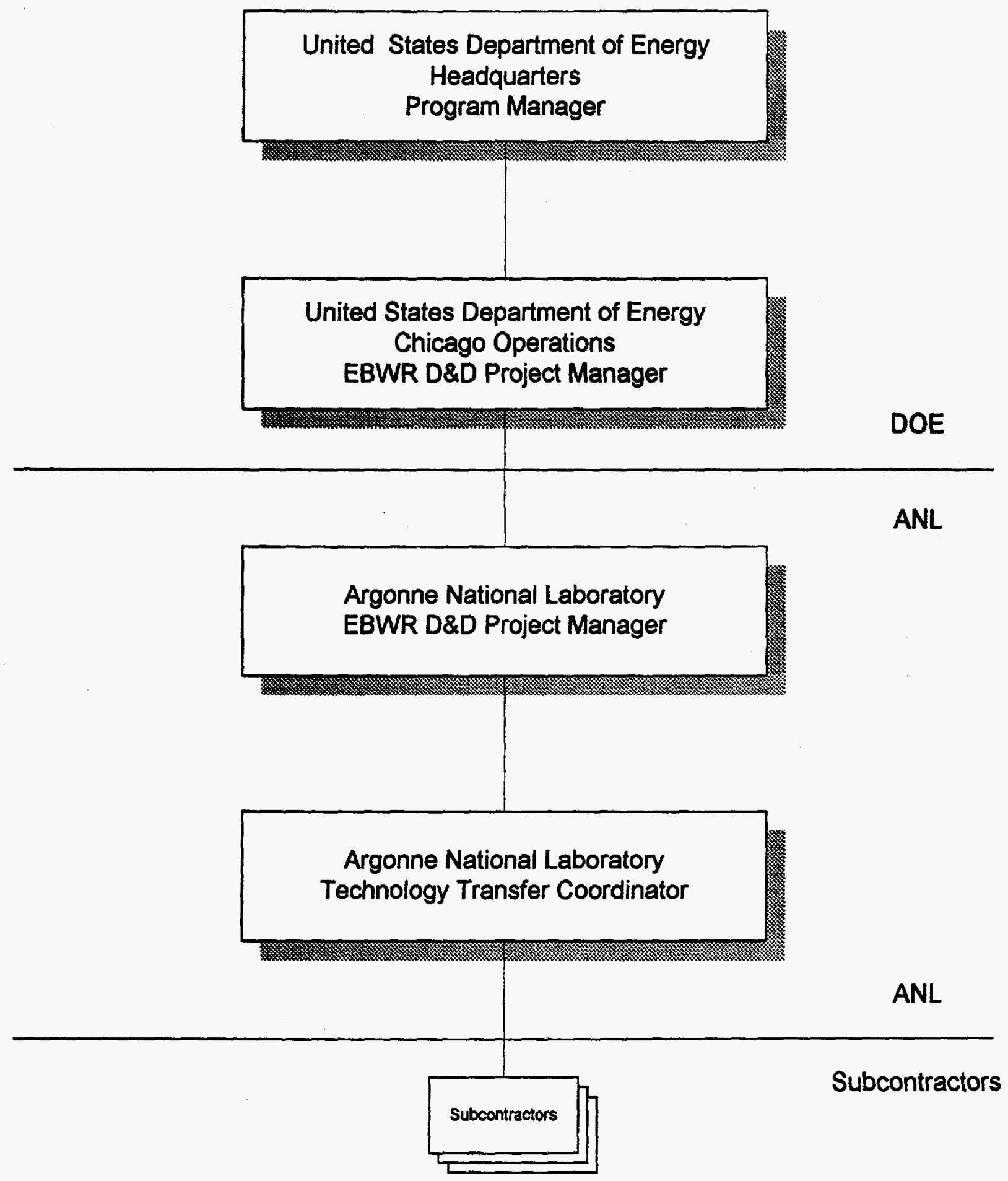

FIGURE 9 EBWR Project Organization through DOE to ANL-E 
- Arranging for radiation measurements and radionuclide identifications to determine the type and activity concentrations of the radioactive decommissioning waste

- Assuring that auditable records are maintained for:

- Radiological instrument surveys and smear surveys

- Air sampling data (both radiological and industrial)

- Radionuclide identification and concentrations

- Personnel radiation exposures

- Materials released for unrestricted use

- Materials packaged and sent for burial

- Industrial hygiene and safety guidance, instruction and training

- Developing work procedures

- Determining the disposition of all structures, materials, equipment and contaminated soil

- Physical decommissioning work

- Overseeing the handling and packaging of all decommissioning waste

- Documenting radioactive wastes for off-site shipment and disposal

- The final radiological characterization of the facility

- Preparing the project D\&D Final Report

Figure 10 shows the relationship between the DOE, ANL-E and subcontractors. Subcontractors worked on various tasks related to this project. ALARON Corporation was hired to conduct D\&D activities and provide HP support for Phases IIIA, IIIB and IV. NES, Inc. was hired to provide technical and engineering support, including the development of the EBWR safety analysis report, cost estimate, etc. Additional subcontractors were hired as needed. The ANL-E project manager was responsible for all subcontracting activities. Figure 11 shows the EBWR D\&D project organization and ANL-E support services respectively. 


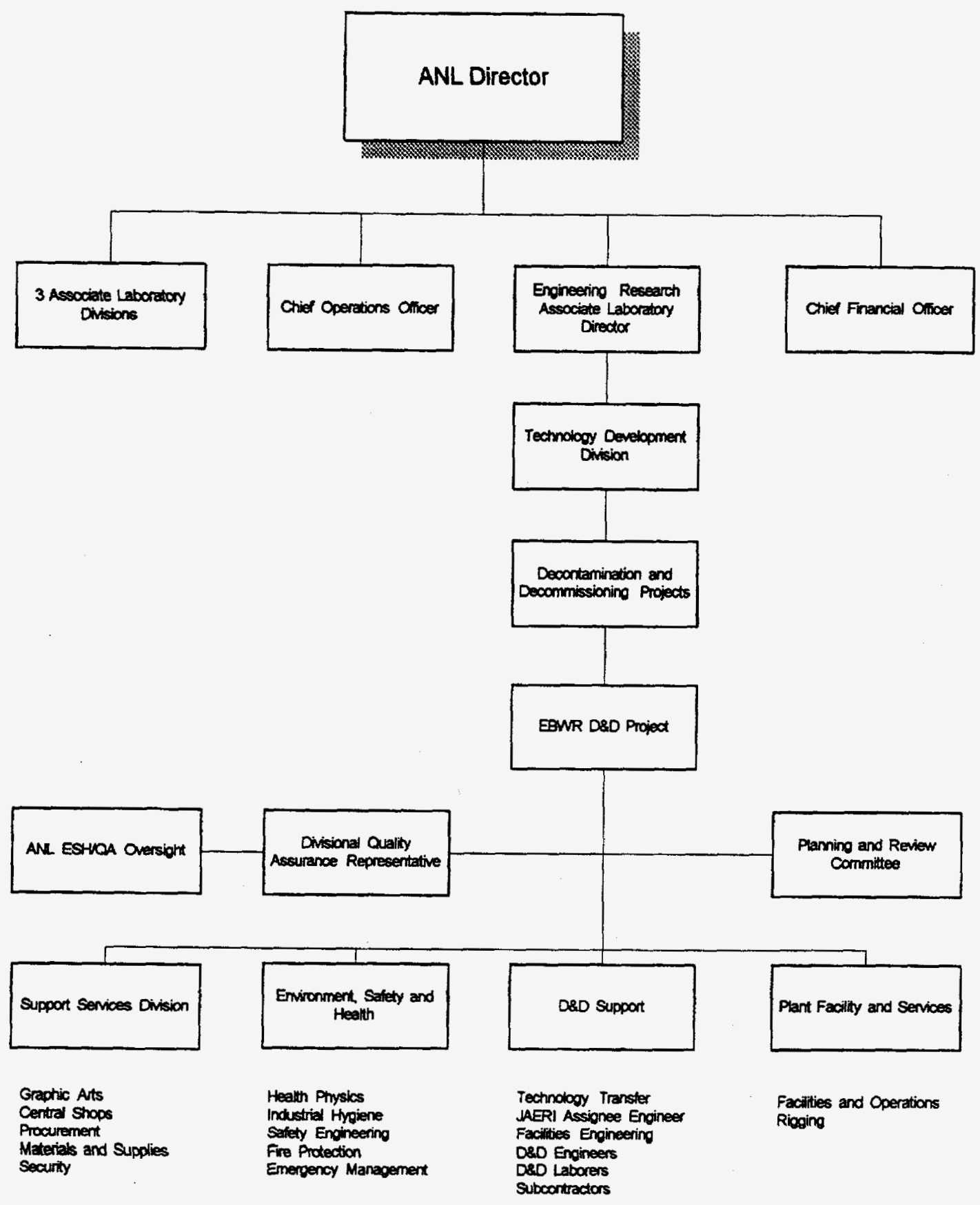

FIGURE 10 Responsibility Structure for D\&D Projects 


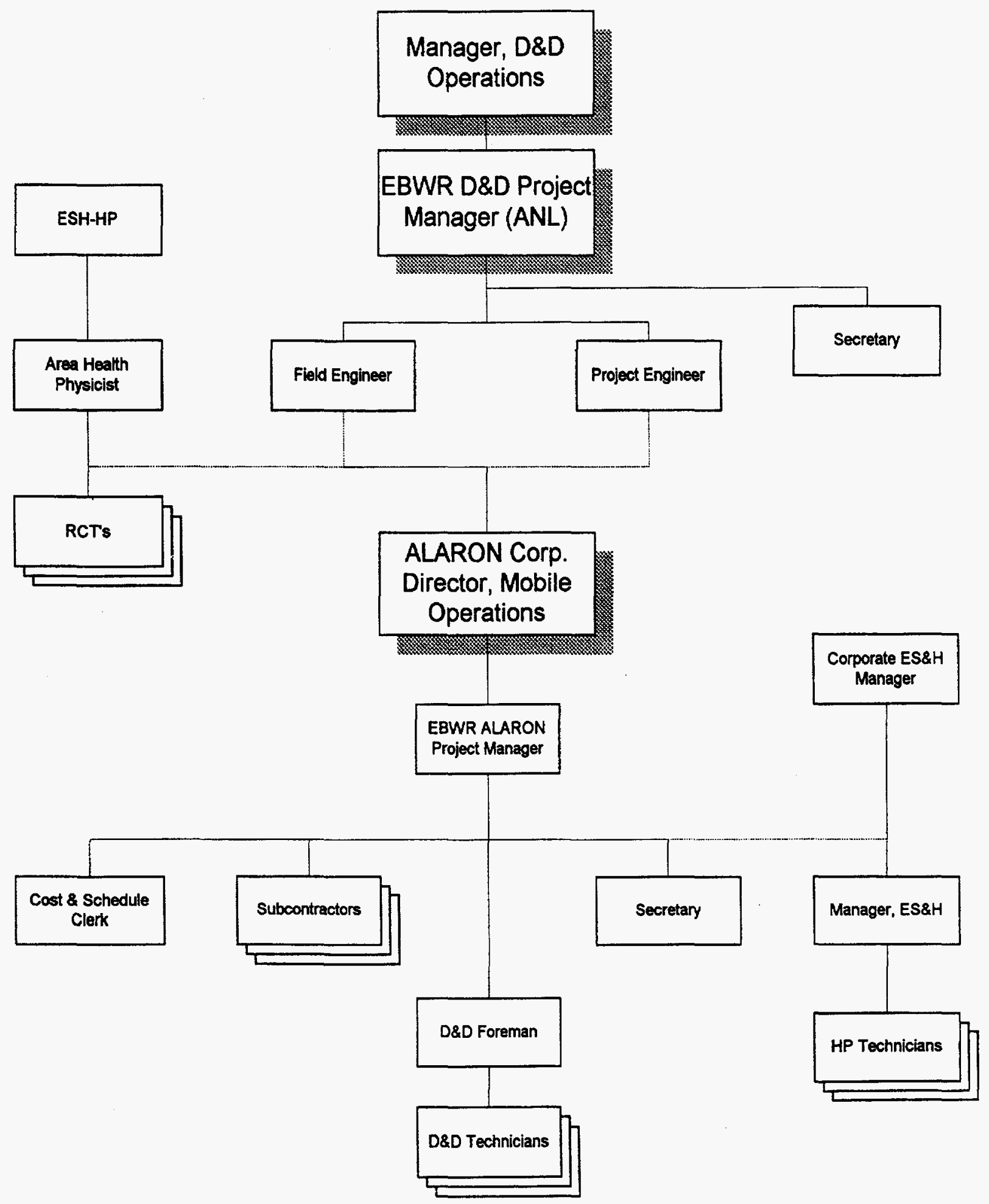

FIGURE 11 EBWR Project Organization at ANL-E 


\subsection{PROJECT ENGINEERING}

\subsubsection{Quality Assurance}

The project quality assurance requirements were based upon existing codes, standards, and practices and most specifically on those found in the current issues of American National Standards Institute (ANSI)/American Society of Mechanical Engineers (ASME) NQA-1 and DOE Order 5700.6C, the ANL-E QA Implementation Guide and the ANL-E QA Planning Guide.

The following activities most relevant to D\&D operations were covered by the project QA requirements:

- Waste segregation as to radioactive and nonradioactive

- Packaging of radioactive waste

- Radioactive content of waste packages

- Instrument calibrations

- QA audits

QA responsibilities were delineated to project management personnel relative to the project QA Plan. The Project Manager had overall responsibility for the execution of project QA requirements. He was helped by the Technology Development (TD) Division quality assurance representative (QAR), and the ESH-HP and Waste Management Operations (WMO) Managers and/or their QARs.

The HP Manager was responsible for complying with the project QA requirements for sampling, sample analysis, standards, instrument calibrations, radiation safety, radiation monitoring, and the final radiation survey of the facility. The HP Manager was also responsible for establishing qualification requirements for the project's HP personnel and for their training, as needed.

The WMO Manager was responsible for compliance with QA requirements for waste packaging and waste disposal activities. He was also responsible for establishing the qualification requirements for the project operating personnel and for their training, as needed during Phases I and II. 
The Environment and Waste Management Program QAR, the ESH Division QAR, and the TD QAR had joint responsibility for the review and approval of the QA requirements with respect to the project. They also served as an interface with the ESH/QA Oversight Office.

ANL-E ESH/QA Oversight was responsible for auditing the project to verify compliance with QA requirements and to determine their effectiveness. ANL-E ESH/QA Oversight also provided guidance and consultation to the Divisional QA Representatives. ESH/QA Oversight served as a third party independent review of project QA.

\subsubsection{Project Control}

The EBWR D\&D Project Manager had prime control and overall responsibility for the project. Details of the project activities were documented in weekly highlights and monthly progress reports submitted to DOE-ARG. The Project Manager reviewed the reports to identify any project deficiencies. The Project Manager also scheduled periodic meetings of project personnel to assess progress and to deal with any problems as they arose. Project status review meetings were held by D\&D program management to gauge project status and issues.

\subsubsection{Project Data}

Data generated during the D\&D activities, including survey results, instrument calibrations, sample analyses, personnel radiation and toxic material exposures, etc., have been retained as permanent records of the project. Appropriate ANL-E management staff reviewed the data to assure that all operations met QA specifications. Compliance was verified by periodic QA audits of the data.

\subsubsection{Training}

All project personnel involved with EBWR decontamination work were previously trained and experienced in routine tasks. Personnel assigned special tasks with which they were unfamiliar were given additional and specialized training by either project personnel or ESH training to enable them to complete the work safely and expeditiously.

\subsubsection{Health Physics}

The ESH-HP personnel were employed to monitor the radiological aspects of the project. These personnel had formal training in their field of specialization and had practical and varied 
radiation monitoring skills. Qualified ESH staff members supervised the HP radiation monitoring personnel and provided additional training as deemed necessary.

\subsubsection{Decontamination}

Subcontractor personnel from ALARON performed the plant dismantling and decontamination activities. ALARON personnel received practical training in their specialty and were experienced in using the various decontamination and dismantling processes and techniques required by the project. Additional training was provided by ALARON as necessary.

\subsubsection{Other Training}

Training in other areas such as rigging and hoisting, respirator usage, industrial safety, etc., were provided on an as needed basis to ANL-E personnel by those ANL-E Organizations who have expertise in such fields. This training included films and videos produced by various outside firms used as appropriate to the project work.

\subsubsection{Health and Safety}

The ESH Division was responsible for the health and safety aspects of the EBWR D\&D project as outline in the ANL-East Health and Safety Manual. The ESH Department, besides approving subcontractor procedures, assigned staff members specializing in Health Physics, Industrial Hygiene and Safety Engineering to monitor the project for identifying and evaluating conditions that might have affected health and safety.

\subsubsection{Planning and Review Committee}

To provide a mechanism for the independent review and approval of the plans and procedures related to this D\&D effort, the EBWR Project Manager appointed a Planning and Review committee consisting of Laboratory technical, operating and safety personnel. This group reviewed proposed plans and procedures and resolved differences that arose regarding methods of operations. The Planning and Review Committee also served as the ANL-E internal safety evaluation committee which recommended approval to the EBWR Project Manager. The EBWR Project Manager ultimately issued final approvals.

Ultimately this process was revised to be replaced by a division Environmental Safety Review Committee (ESRC) review process where the ESRC reviewed procedures and RWP 
packages combined into Task Work Packages. These were approved by the Project Manager, reviewed by the TD ESRC, approved by TD management and then reviewed and approved by DOE.

\subsubsection{Radiation Safety}

Data concerning the radiological exposure of project personnel was collected, recorded, and analyzed by members of the ESH division. Project HP personnel made recommendations regarding project safety procedures and criteria for D\&D activities and for radioactive waste disposal. They also reviewed project work procedures and monitored project activities with the objective of identifying potential radiological hazards and eliminating or controlling them. These recommendations embodied the "As Low As Reasonably Achievable" (ALARA) principle.

\subsubsection{Industrial Hygiene}

Staff members of ESH/Industrial Hygiene furnished technical guidance in toxic materials handling (primarily for asbestos), respiratory protection, ventilation and protective clothing. Additionally, they tested HEPA and respiratory filters, monitored for toxic material exposures, and gave trained personnel in respirator usage. Data obtained from these activities were evaluated to determine if further mitigating measures were needed and retained as part of the permanent project records.

\subsubsection{Industrial Safety}

The industrial safety aspects of the project were reviewed by staff members of ESH who were specialists in the field of Safety Engineering. They evaluated the potential exposure of personnel to accidental injury hazard and recommended means to minimize such occurrences.

\subsubsection{Fire Protection and Security}

Project fire protection services and safety guidance were provided by the ANL-E Fire Department. They made periodic tours of the work site to assess fire potential and advised EBWR D\&D project management on potential improvements. Physical security was provided by the Laboratory contractor security forces. 


\subsection{CONDUCT OF OPERATIONS}

Internal division and program operational and administrative procedures were followed during the EBWR D\&D project. Applicable conduct of operations topics included:

- Organization and administration

- Communications

- Investigation of abnormal events

- Control of equipment and system status

- Logkeeping

- Postings

- Labeling

\subsection{SITE CHARACTERIZATION}

In August 1979, accessible areas of the EBWR containment building were radiologically surveyed. This survey showed that there were significant but not necessarily high radiation levels in various locations within the building, primarily due to the radioactive isotope $\mathrm{Co}^{60}$. This activation product resulted from the irradiation of small amounts of $\mathrm{Co}^{59}$ that are present as an impurity in the metal used to form the reactor vessel. After 12 years of safe storage, the highest radiation levels occurred in the basement where a gamma reading of 300 milliroentgen $(\mathrm{mR}) / \mathrm{hr}$ was measured at a purification system regenerative cooler. Gross beta-gamma activities ranged from 27.3 to $650 \mathrm{~Bq} / 100 \mathrm{~cm}^{2}\left(1,640\right.$ to $\left.39,000 \mathrm{dpm} / 100 \mathrm{~cm}^{2}\right)$ were measured from smear samples taken in this location. Significant gamma radiation was also detected at the reactor water level column, which measured up to $70 \mathrm{mR} / \mathrm{hr}$. Elevated radiation levels were also detected on the steam dryer, the desuperheater, and along a piping run by the deaerator. These latter areas were measured at from 3 to $30 \mathrm{mR} / \mathrm{hr}$ gamma. The reactor vessel was not radiologically surveyed in 1979 .

In February 1983, ANL-E conducted measurements of the radiation field in the reactor vessel. These were made using a Victoreen Radcon 550 ion chamber instrument introduced into the 
vessel through an instrument port. Based $c$ of the radiation impinging on the instrume primarily on the core shroud and the reactc iese measurements and on the assumption that most sbe was $\mathrm{Co}^{60}$ photons contributed by activated steel, isel, radiation fields were estimated to be as follows:

- Reactor Vessel10 R/hr @2"

- Core Shroud306 R/hr@2"

A similar survey of the inside of the vessel was made in February of 1989. The results of this survey are summarized in Figure 12.

\subsection{ALTERNATIVES ASSESSMENT}

The alternative to D\&D was to store the facility in the dry lay-up condition for an indefinite period (known as Safe Storage). Due to the degrading condition of the building, the inherent radiological risk, the need to use the area occupied by the facility, and escalating waste disposal and D\&D activity costs, this option was rejected. 


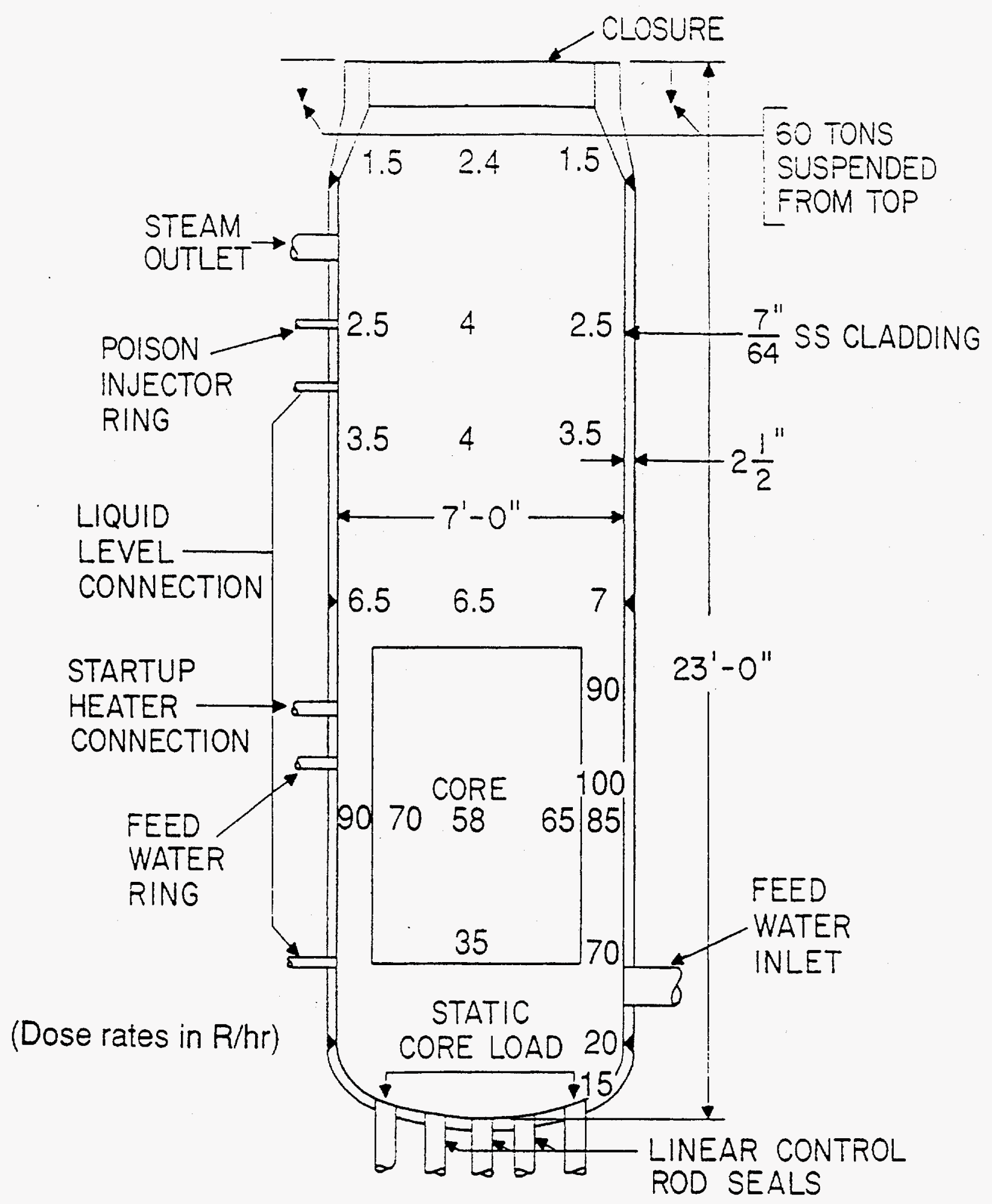

FIGURE 121989 Survey of the Reactor Vessel 


\section{DECOMMISSIONING OPERATIONS}

\subsection{GENERAL}

The ANL-E WMO crew was selected to perform Phase I and II of the D\&D work due to their extensive experience in the types of D\&D tasks planned to take place during these phases. Costs were kept as low as possible using this approach. A subcontractor was chosen to do the Phase III and IV work due to the large number of personnel required to accomplish the work in a compressed time frame. General D\&D activities were conducted in the following manner:

\subsubsection{Facility Contents}

All unattached items of equipment, furniture, and debris were removed from the facility to clear it for further D\&D work. These items were surveyed for radioactivity as they were removed and if contaminated, were packaged for burial as radioactive waste. Uncontaminated material was salvaged for reuse or scrap disposal, or disposed of in the ANL-E landfill. Installed equipment such as the turbine-generator, the condenser, and motors, pumps, tanks, compressors, etc., was decontaminated wherever possible, and salvaged for scrap. If decontamination was not possible, items were size reduced as necessary and packaged for burial as radioactive waste.

\subsubsection{Piping, Conduit and Ductwork}

All process piping, conduit, and ductwork were surveyed internally for radioactive contamination during removal whenever possible. Otherwise, items (except the conduit) were disposed of as radioactive waste even if surveys of their outer surfaces showed no radioactive contamination. The piping of systems known to be "closed," such as domestic and laboratory water, air, and the laboratory steam heating system, and the conduit were surveyed on their exterior surfaces and at open ends only. Piping and ductwork that was uncontaminated after a survey of the internal and external surfaces were salvaged for reuse, disposed of as scrap, or placed in the ANL-E landfill.

\subsubsection{Interior Walls and Ceilings}

The surface of each wall and ceiling were surveyed for radioactive contamination. Decontamination techniques were used to remove any residual activity. 


\subsubsection{Floors and Gratings}

Floors and gratings were first cleaned of all debris and dust. Floor coverings were removed, surveyed and disposed of as appropriate. The exposed floor surface was also surveyed for radioactive contamination. Any portion of the floors or gratings of the facility found contaminated was decontaminated by use of appropriate techniques. Concrete surfaces were scrabbled to decontaminate them where scrubbing with cleaning solutions was not effective. Gratings that could not be effectively decontaminated were disposed of properly.

\subsubsection{Underground Piping}

Underground piping associated with the operation of the reactor was excavated and surveyed. All materials identified as radioactive were disposed of as radioactive waste. Radiological measurements and air sampling was performed during this work.

\subsubsection{Contaminated Soil}

Soil exposed by the removal of underground piping was surveyed for radioactive contamination, sampled, and analyzed for radioactive content. Radioactively contaminated soil was removed and placed in radioactive-waste shipping containers for disposal.

\subsubsection{Asbestos}

Samples of materials suspected of containing asbestos were submitted to the ANL-E Industrial Hygiene Group for positive identification before removal. Workers followed Environmental Protection Agency and DOE guidelines and used protective clothing and respiratory protective equipment approved by the National Institute for Occupational Safety and Health (NIOSH) during all asbestos removal operations. The asbestos-bearing material was removed in a way that minimized shredding and air contamination, and was packaged and sealed in approved asbestos disposal bags. Asbestos-bearing material containing radioactivity was packaged and disposed of as radioactive waste; otherwise, it was disposed of in the ANL-E on-site landfill.

\subsection{PHASE I - PREPARATORY ACTIVITIES}

Phase I included preparatory activities associated with EBWR D\&D Project. This included a review of all existing documentation, reports, and radiological surveys. This review was limited by the lack of important informational sources including "as built" drawings and accurate records 
from the EBWR period of operation. Figure 13 details Phase I activities. Activities completed during Phase I included the following:

- A base of operations was first established close to the work site. The base included office(s), locker and shower facilities, storage space for equipment, tools and materials, shop space, and a main entry way including a truck lock and step-off pad. Additionally, emergency and temporary power/light services were established.

- A liaison with appropriate ANL-E organizations was established to coordinate the provision of laboratory services to the project. These included emergency and medical services (i.e., ambulance, fire protection, medical personnel, and rescue equipment).

- All project personnel were trained as part of Phase I activities. Additional new staff was trained as added to the project. Radworker Training I and II, Occupational Safety and Health Administration (OSHA), and other required training was provided at this time. Personnel who had completed this training previously could test out of the required training when appropriate. Training in specific project operations were provided at this time and later as required.

- Project supplies including tools, equipment, decontamination materials, and radioactive-waste shipping containers were procured at this time.

- A marshalling area in the yard southwest of the containment shell was established. Items removed from the facility were prepared for shipment, and required equipment and supplies were assembled in this area. The large, temporary hatchway in the southwest side of the containment shell on the main floor level was also reopened. A truck enclosure for moving large items out of the shell and ensuring satisfactory containment for the shell was fabricated and installed.

- Miscellaneous activities, including recertifying the polar crane in the containment shell, performing necessary safety related construction activities, removing unneeded nonradioactive systems and components to provide better access for asbestos removal and other D\&D operations, and the removal of all asbestos bearing material from the facility. 


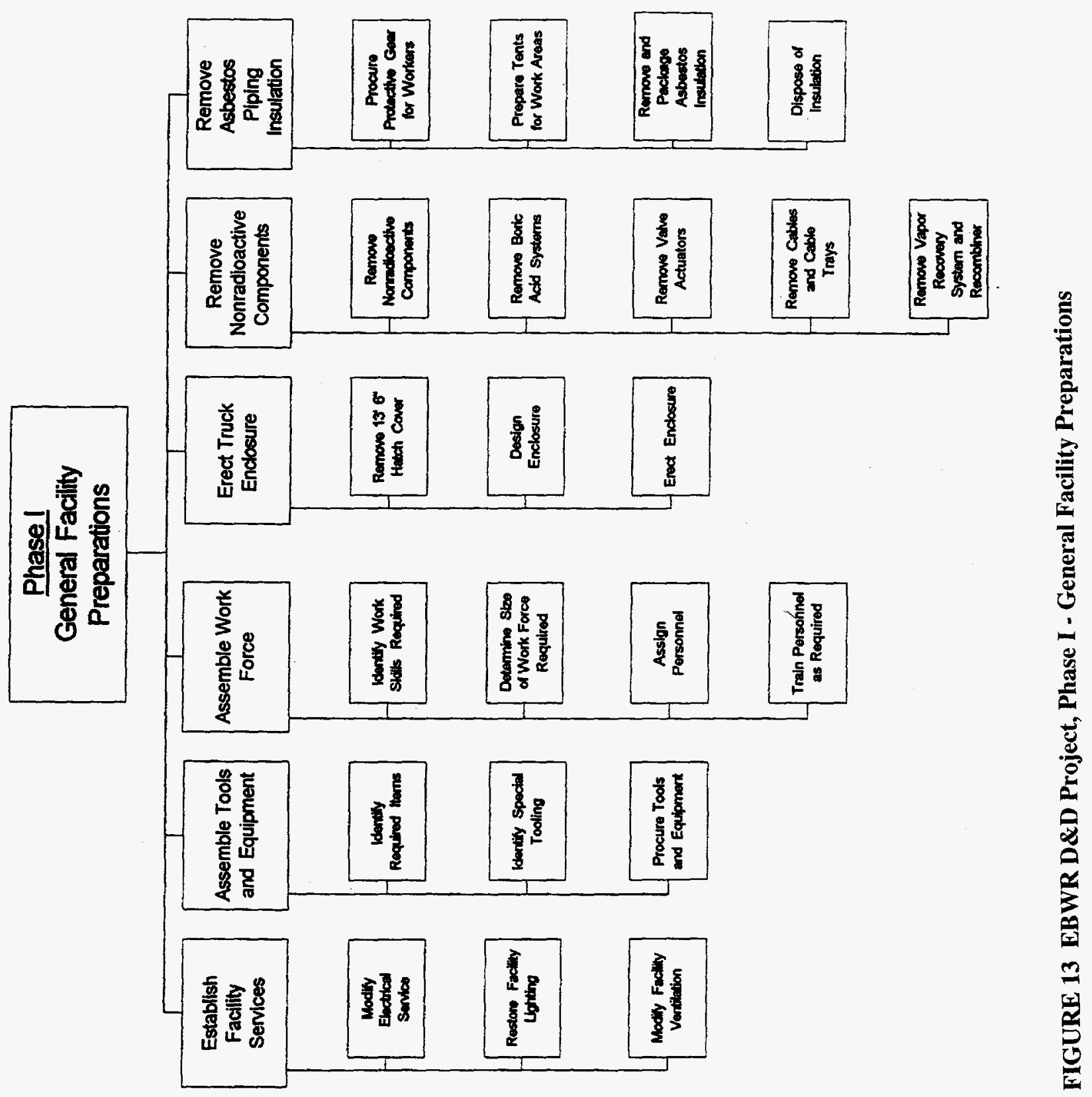




\subsection{PHASE II - REACTOR SYSTEM PIPING, COMPONENTS AND ASSOCIATED EQUIPMENT}

Figure 14 shows the tasks carried out in Phase II. The turbine-generator was disassembled and removed, followed by a general cleanup of the plant. The condenser and circulation water systems, and all steam piping, were removed and size reduced for packaging using conventional power tools (sawz-alls, portable band saws, air saws), plasma arc, and oxyacetylene torches.

Decontamination of larger equipment items, including the condenser unit, was very effective. These decontamination efforts using conventional sand blasting equipment released about $90 \%$ of these components to the on-site metal recycler. The Spent Fuel Pool was also cleaned out, drained, and repainted. At this time a thorough general cleanup of the EBWR Building (Shell) was conducted. After the completion of Phase II, safety railings were built around areas or in areas as deemed necessary by the project staff to maintain a safe work area.

The turbine generator received virtually no decontamination. The generator and exciter were clean, but the turbine rotor and casing required disposal as radioactive material.

\subsection{PHASE III - REACTOR DISASSEMBLY}

\subsubsection{Mobilization}

Preparations for Phase IIIA and IIIB included the design and construction of a Water Filtration and Transfer System for the fuel pool and a $113.2 \mathrm{~m}^{3} /$ minute $(\mathrm{min})(4,000$ cubic feet per minute) HEPA filtration system near the reactor vessel to filter out airborne radioactivity during cutting operations and to provide fresh air turnover during operations. All required training was provided by ALARON and/or ANL-E HP, as required. ANL-E Central Shop constructed mockups of the reactor vessel and internals, and mobilization activities included mockup training. Figure 15 shows the mock up core assembly used for training purposes compared with the actual core assembly. Additional electrical outlets and wiring were added, the gantry crane was installed and work tables were built, and a four-camera remote video system was installed.

Three different shields were also constructed at this time. A basket shield was designed to transfer the basket containing the irradiated hardware segments to a 208 liter (55 gallon) drum. The basket shield contained a " $\mathrm{T}$ " rigging surrounded by a lead shield. A drum shield was constructed identical to a basket shield except for the " $T$ " handle. This handle was replaced with a vacuum lift used to transfer the drum. Additionally, a control rod shield was manufactured for the transfer of the control rods. These shields covered the highly radioactive middle portion of the control rods. 


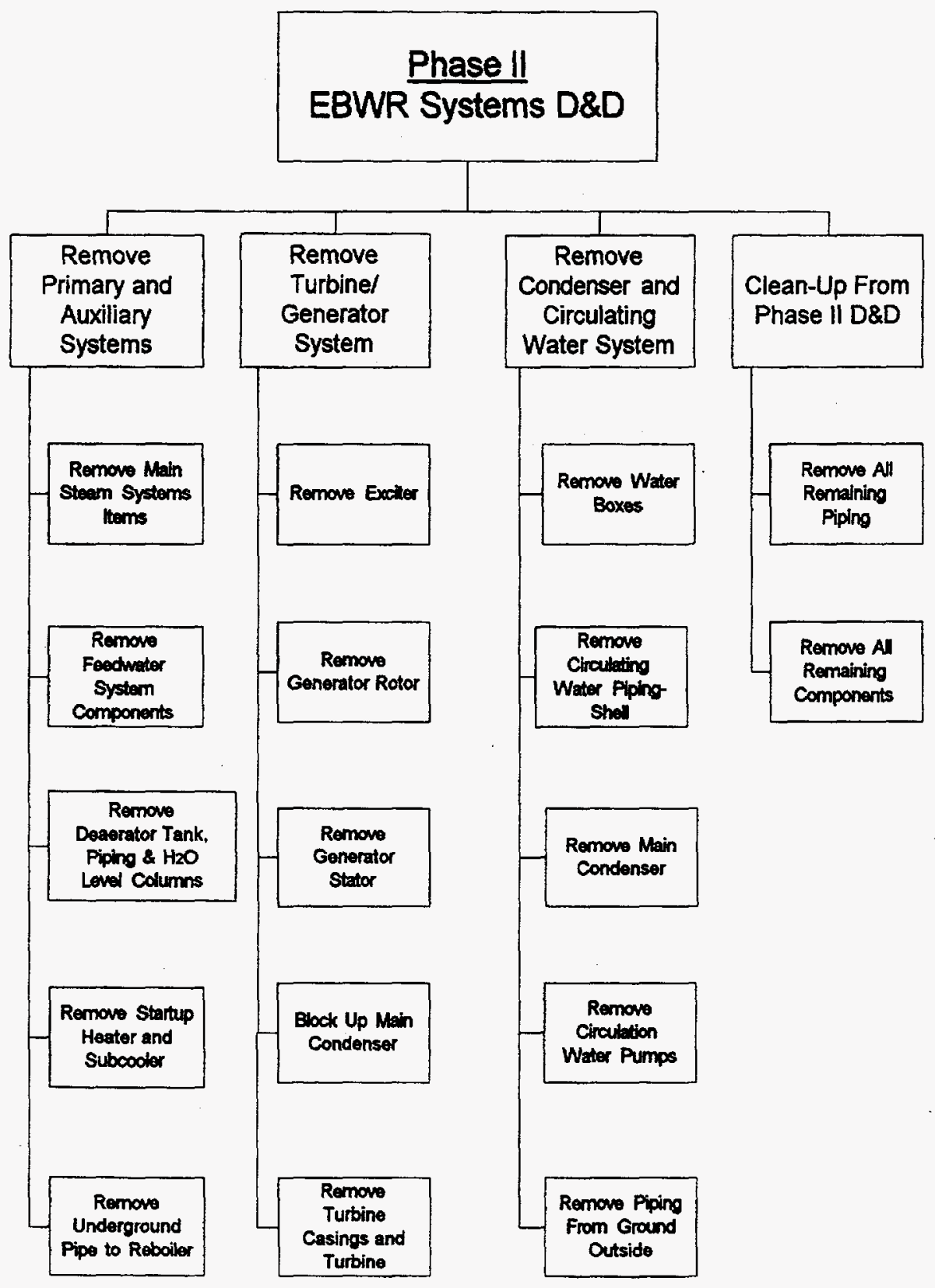

FIGURE 14 EBWR D\&D Project, Phase II - EBWR Systems D\&D 

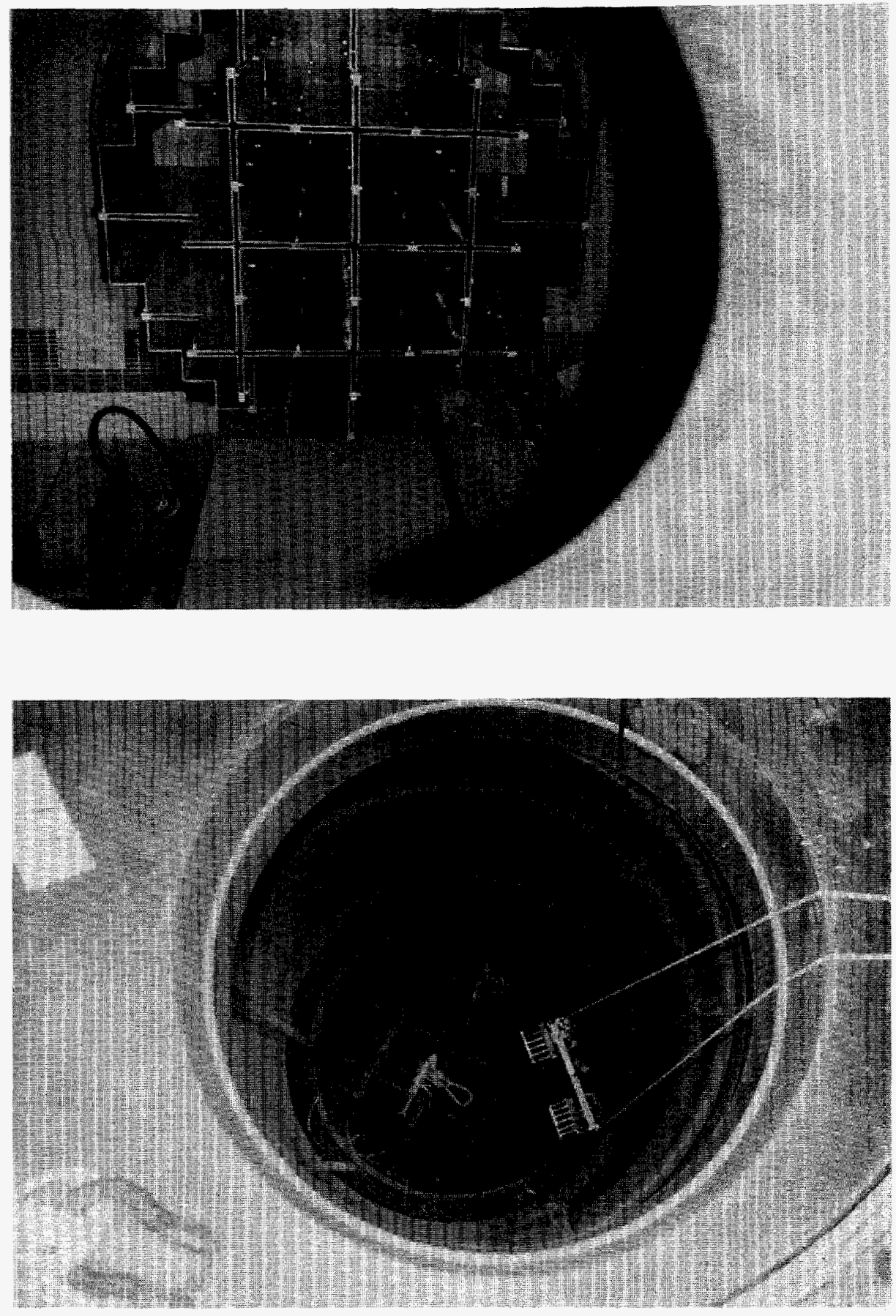

FIGURE 15 Mock-Up vs. Actual Core Assembly (ANL Negative \#20098K, Frames \#6 and \#10) 
Figure 16 shows the tasks carried out during Phases III (Mobilization), IIIA (Reactor Vessel Internals Removal), and IIIB (Reactor Vessel Removal).

\subsubsection{Phase IIIA - Reactor Vessel Internals}

Phase IIIA consisted of removing all reactor internals, transfer of them to the pool, and size reducing these internals. Phase IIIB consisted of removing and size reducing the reactor vessel. Phase IIIA D\&D activities started in March 1994. ALARON provided D\&D and HP technicians to perform the tasks involved with Phases IIIA and IIIB of the D\&D. During March 1994, the control rods and the reactor core assembly were removed from the reactor and placed in the fuel pool for size reduction and packaging. The core assembly had contact dose rates of up to $200 \mathrm{R} / \mathrm{hr}$.

Figure 17 shows the sequence of the removal of the Index Plug to the reactor. The first picture shows the plug in place. The second picture shows the removal of the index plug. Figure 18 shows the removal of the core assembly from the reactor to the fuel pool for size reduction.

In April 1994, the underwater size reduction of the reactor core assembly began using a 45-amp underwater plasma arc torch. All remaining reactor internals (such as the steam ducts, shock shields, thermal shields and experimental appendages) were removed from the vessel using the plasma arc system and were transferred to the fuel pool for further size reduction as needed (See Figure 19). All reactor vessel nozzle penetrations were cut flush to the reactor vessel using a splitframe pipe cutter provided by Wachs Technical Services (WTS). An access manway was cut through the reactor vessel into the reactor vessel as a personnel and equipment access. Thirteen drums of remote handled irradiated hardware was removed from the pool in July 1994. Contact dose rates ranged from $1 \mathrm{R} / \mathrm{hr}$ to $9 \mathrm{R} / \mathrm{hr}$ on these drums. These consisted of primarily the cut up core assembly pieces. Work continued size reducing irradiated hardware in the fuel pool until September 9, 1994. At that time the Project Manager stopped all D\&D work at EBWR due to positive bioassay results. Twelve workers had $\mathrm{Am}^{241}$ uptakes and nearly all workers had some amount of tritium uptake. An investigation into the cause of these internal exposures was started and continued through December 1994. Adequate data was available by early November 1994 to suggest that the source of $\mathrm{Am}^{241}$ and $\mathrm{H}^{3}$ was found in the fuel pool, so limited work was allowed in the non-fuel pool D\&D areas (see Section 9).

Size reduction of the reactor internals continued until the work stoppage in September 1994, and resumed when work was restarted in February 1995. In December 1994, the project completed an Argonne Operational Readiness Review (ORR) for the restart of D\&D activities at EBWR. During January and February 1995 the project completed a DOE ORR and resumed work on February 15, 1995. The recirculation pipes were removed from the Reactor Cavity walls, allowing a survey of the cavity to begin. 


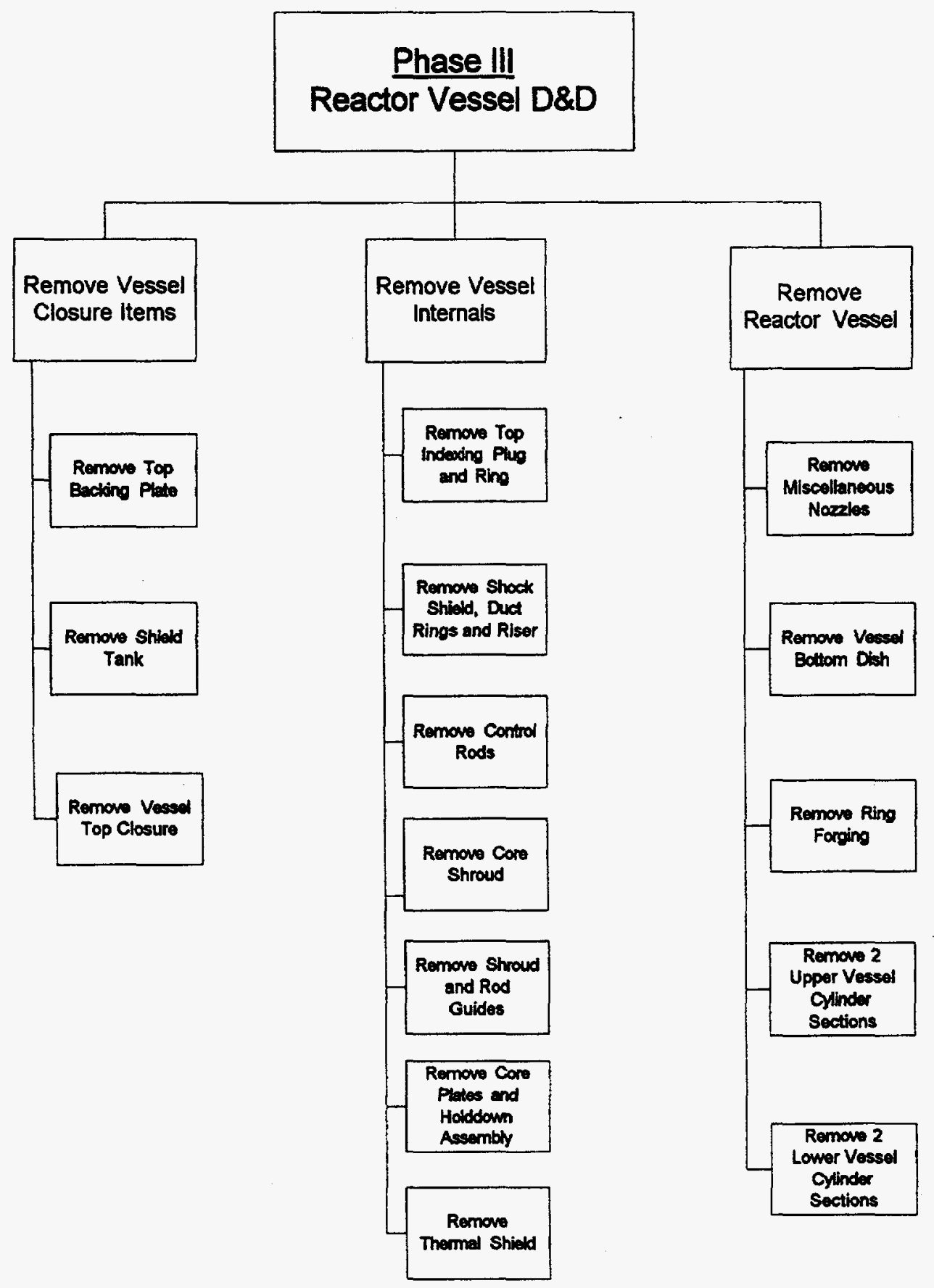

FIGURE 16 EBWR D\&D Project, Phase III - Reactor Vessel D\&D 

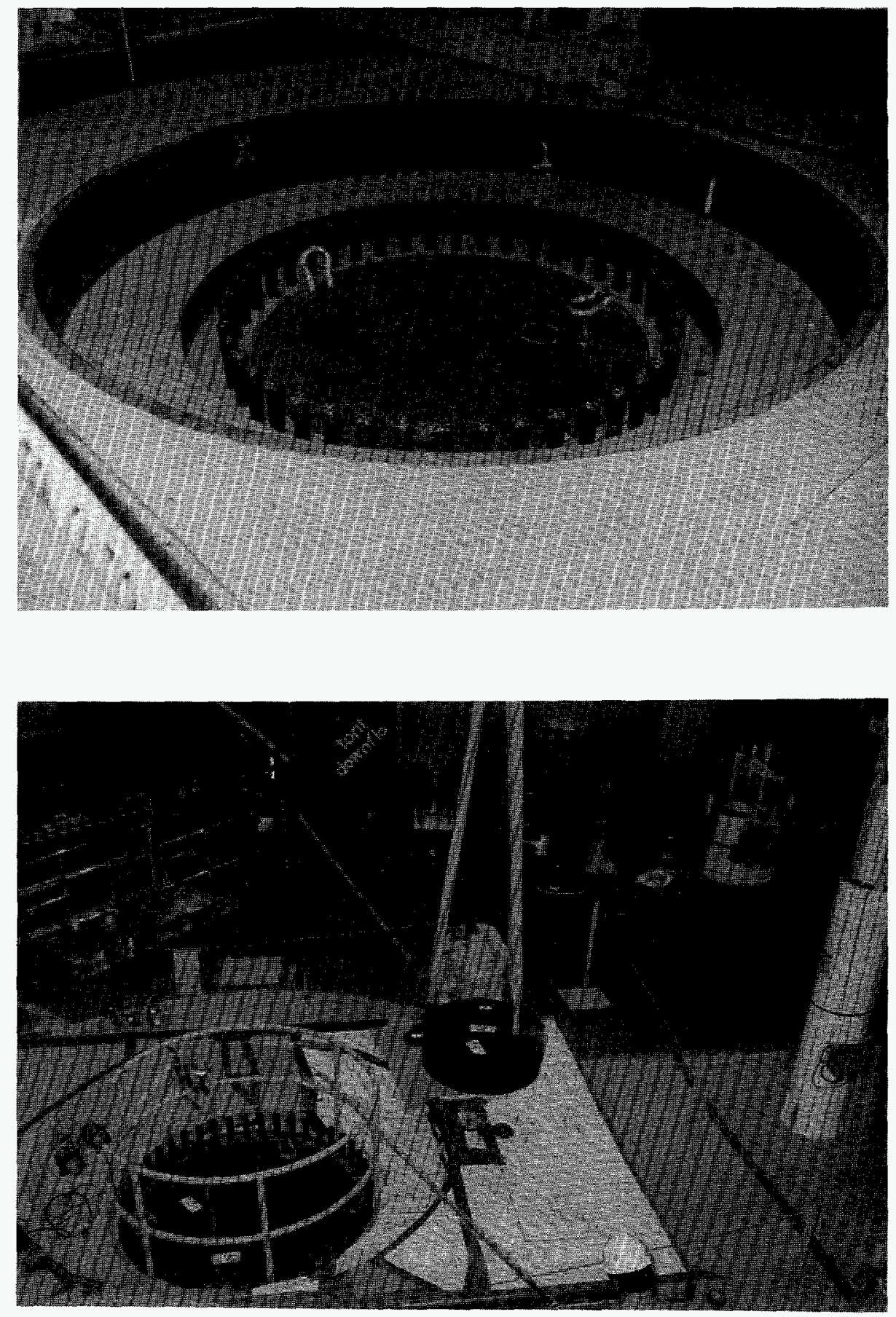

FIGURE 17 Removal of the Index Plug (ANL Negative \#20098K, Frames \#11 and \#12) 

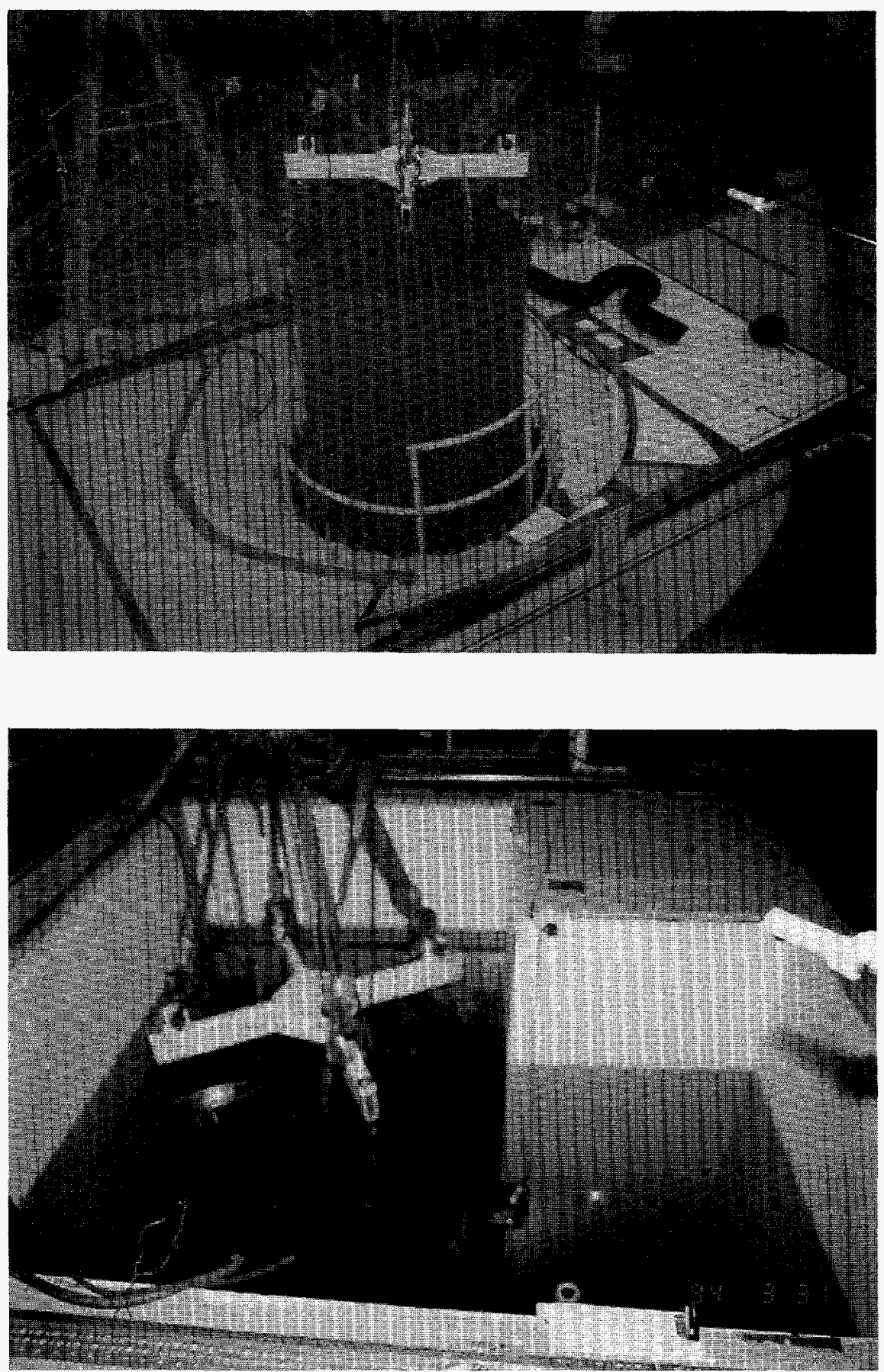

FIGURE 18 Removal of the Core Assembly from the Reactor Vessel to the Fuel Pool (ANL Negative \#20098K, \#13 and \#15) 

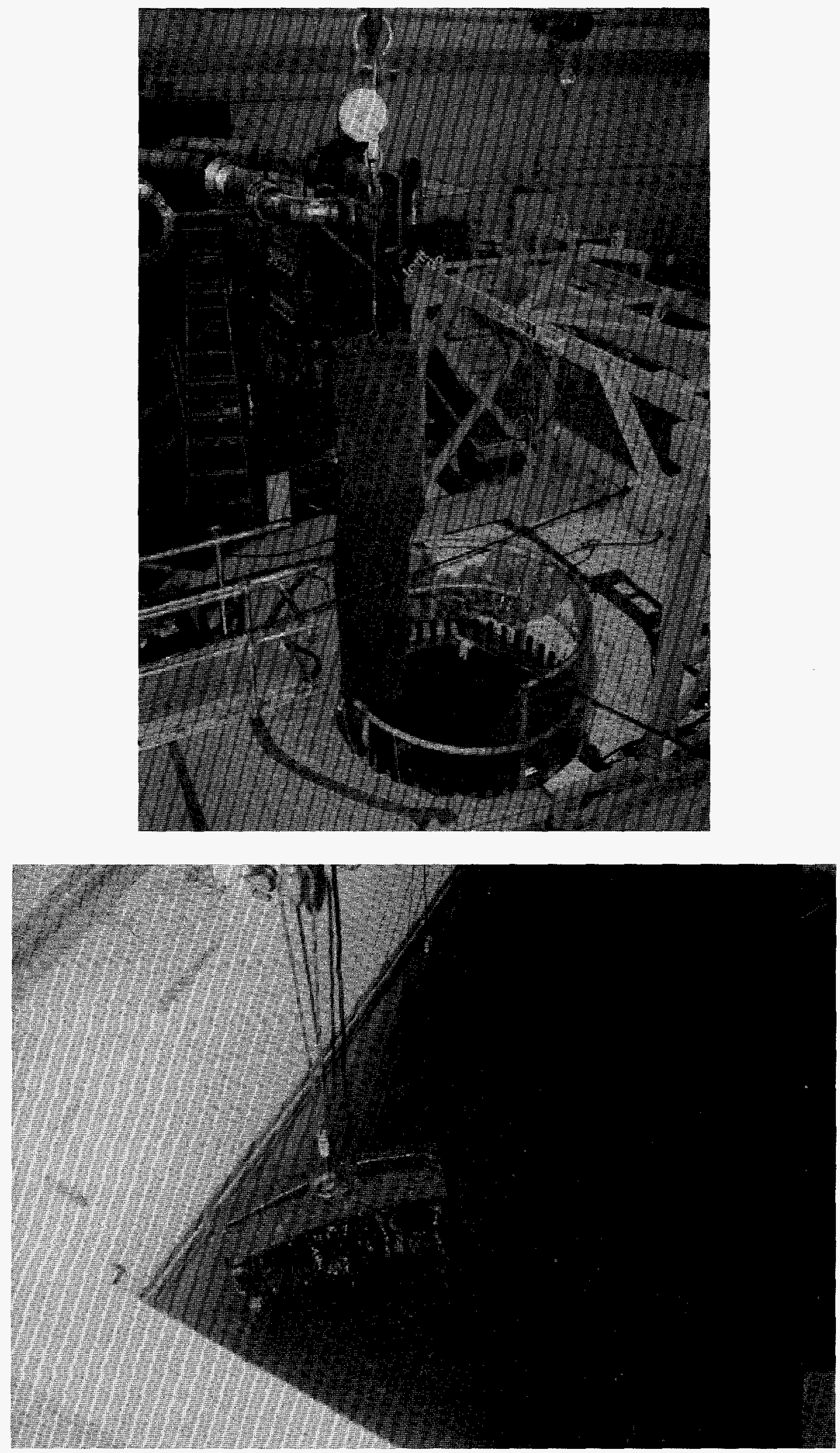

FIGURE 19 Removal and Transfer of a Section of the Reactor Thermal Shield (ANL Negative \#20098K, Frames \#14 and \#16) 
The loading of irradiated hardware segments from the fuel pool to the transfer casks involved the use of the basket shield and the drum shield. High dose rate items were cut in the fuel pool and loaded into a basket. A basket shield was designed to transfer the basket containing the irradiated hardware to a 208 liter (55 gallon) drum (see Figure 20). The basket shield contained a "T" rigging surrounded by a lead shield. The shield covered the basket. Inside the shield, the basket was loaded using the "T" rigging. The loaded basket shield was then lifted and "piggybacked" onto the drum shield. The drum shield was a lead shield containing a 208 liter ( 55 gallon) drum. The drum shield was constructed identical to a basket shield except for the "T" handle. This handle was replaced with a vacuum lift used to transfer the drum. Once the basket was transferred to the drum, a drum was sealed within the drum shield. The vacuum lift was then used to transfer the drum within the drum shield to the transfer cask.

The control rods were removed in a similar manner. The control rods were transferred from the reactor to the fuel pool using the control rod shield (see Figure 21). This shield covered the radioactive middle portion of the control rods. The control rods were then sectioned and transferred in baskets as described above.

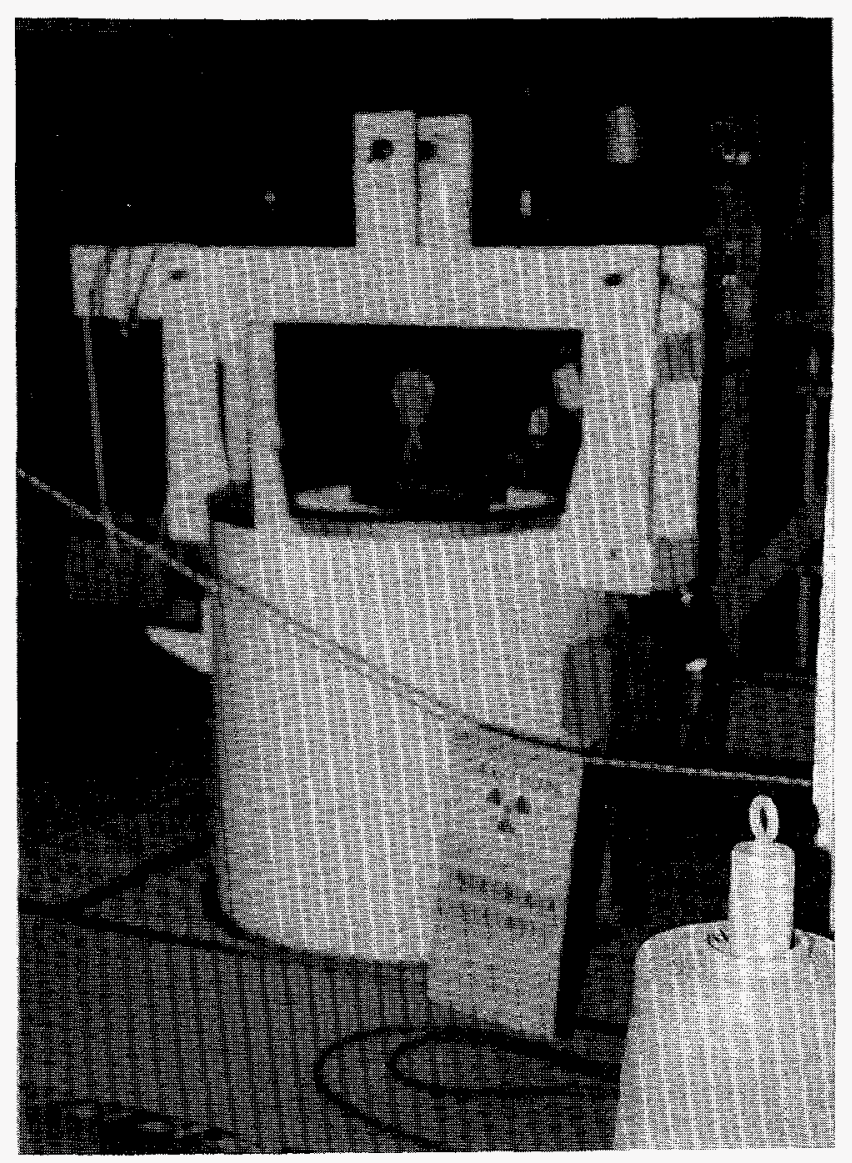

FIGURE 20 Drum Shield (ANL Negative \#20098K, Frame \#17) 


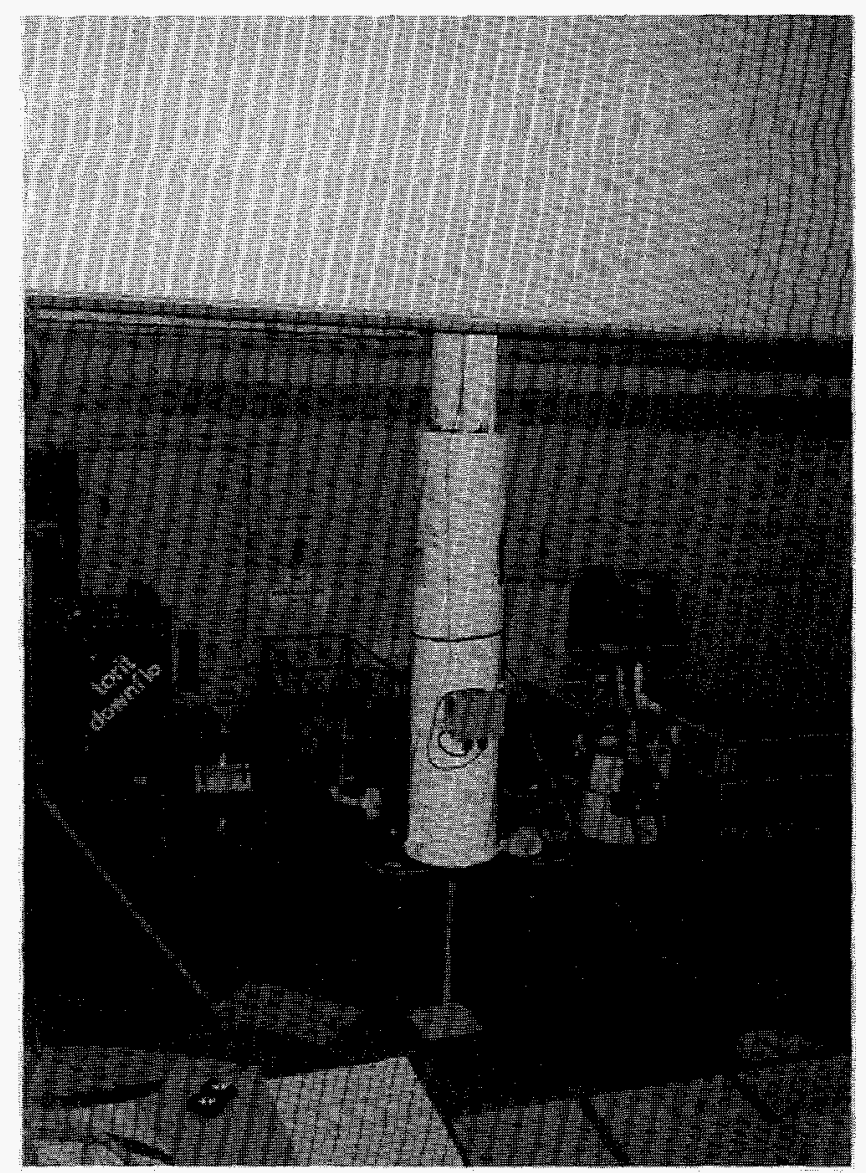

FIGURE 21 Control Rod Shield

(ANL Negative \#20098K, Frame \#18)

The cutting and transfer of the irradiated reactor internals hardware comprised the greatest exposure source to project personnel. The use of the drum, basket, and control rod shields (in addition to mock training sessions enacted Phase III mobilization) significantly reduced the total dose received to project personnel from the estimated dose (see Section 9).

In March 1995, six baskets of irradiated hardware were removed from the fuel pool and packaged for disposal. The transfer shields were used for irradiated hardware handling during transfer of the drums to WMO for storage until final shipping and disposal. The shields performed as planned and personnel exposure was acceptable for all packaging operations. Contact dose rates on the baskets ranged from $2 \mathrm{R} / \mathrm{hr}$ to $200 \mathrm{R} / \mathrm{hr}$. After D\&D activities restarted in February 1995, work resumed in the fuel pool size reducing the core support plate. All items in the fuel pool were size reduced, packaged and disposed of by June 1995 (Figure 22). 

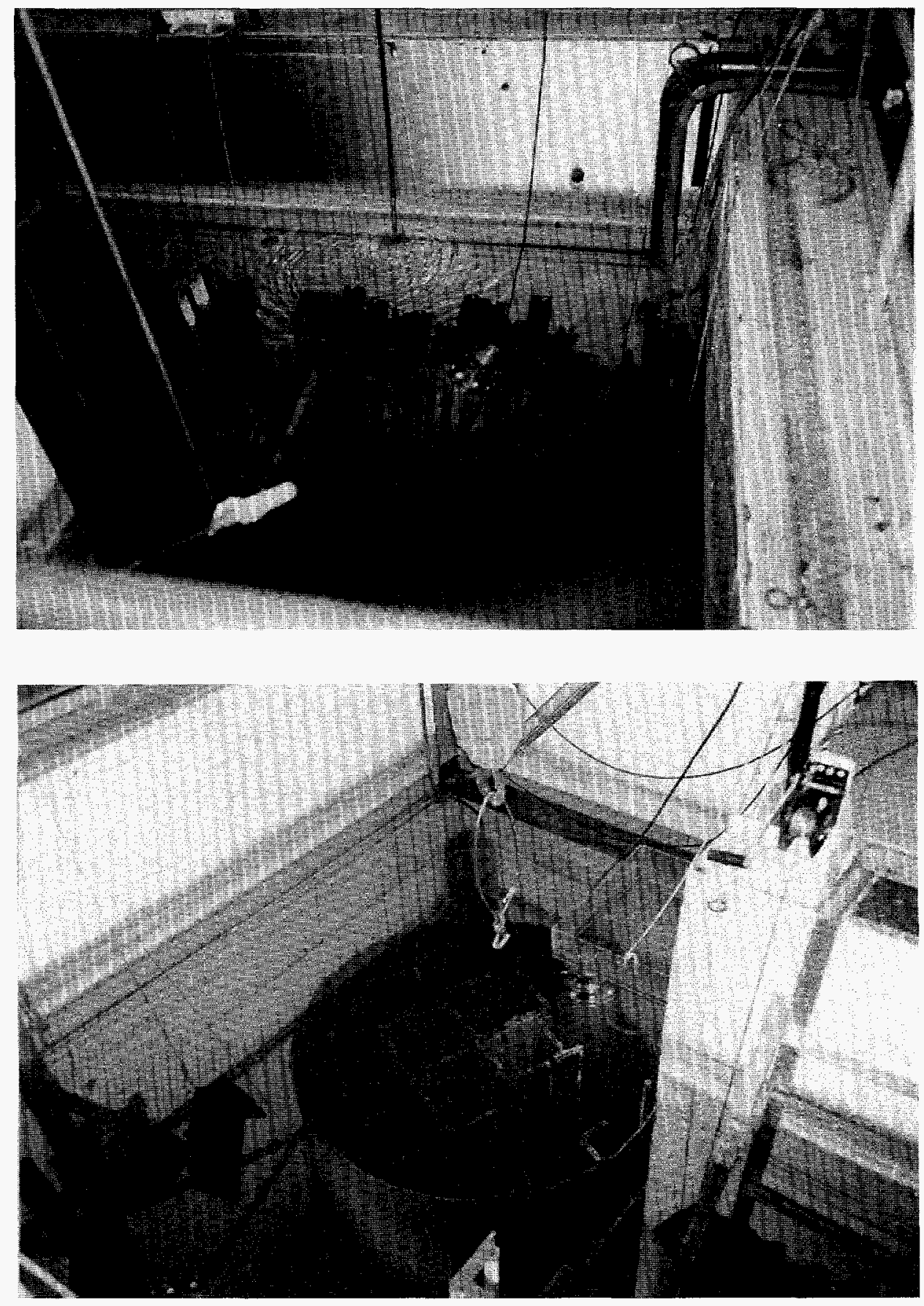

FIGURE 22 Items in Fuel Pool to be Size Reduced (ANL Negative \#20098K, Frames \#19 and \#20) 


\subsubsection{Phase IIIB - Reactor Vessel}

Phase IIIB activities ran concurrently with Phase IIIA activities. In May 1994, the reactor vessel was cut and removed. WTS segmented the vessel using a split-frame inside diameter cutting machine (See Figures 23 and 24). The vessel bowl was cut first and the bowl piece removed. The vessel barrel was cut four times, producing five ring segments. Each ring was lowered to the bottom of the vessel cavity until all cuts were completed. The top vessel section was then removed and staged in a holding area on the 4th level of the containment building. Each additional ring was removed, with the last ring being placed in the cutting tent for additional size reduction. Figures 25 and 26 show the removal of the top vessel section and the remaining four vessel sections. The reactor cavity was cleaned in preparation for core boring operations and cavity liner cutting and removal. During June 1994, reactor vessel ring size reduction and packaging was completed, accomplishing these tasks two weeks before the DOE milestone date. The reactor cavity lower shield plug was removed and core bores of the bioshield were obtained. A 15 meter (50 ft) test was made using a FLOW abrasive water jet. The steel cavity liner was segmented using a WTS split-frame inside diameter cutting machine (see Figure 27). A total of $15909 \mathrm{~kg}(35,000 \mathrm{lb}$ ) of concrete and $3591 \mathrm{~kg}$ $(7,900 \mathrm{lb})$ of steel were free-released for recycling or scrap. Data for each method of reactor vessel cutting used is shown in Table 1 . Table 2 presents metal cutting methods used at EBWR.

In July 1994, removal of the reactor cavity liner was completed. Approximately three thousand $22.7 \mathrm{~kg}(50 \mathrm{lb})$ individual lead bricks were removed from the bioshield. Approximately $61,136 \mathrm{~kg}(134,500 \mathrm{lb})$ of this lead $(90 \%$ of the total) was surveyed and free-released for recycling (see Figure 28). This lead will be smelted and formed into shield blocks for the Advanced Photon Source Accelerator at ANL-E.

\subsection{PHASE IV - BIOLOGICAL SHIELD}

Removal of the activated portion of the bio-shield concrete began in August 1994. This work was accomplished using the BROKK electro-hydraulic remote controlled impact machine (see Figures 29 - 31). One retention tank was removed from Level 1 and placed into the cutting tent for size reduction and packaging. The activated portion of the concrete bioshield was removed during November and December 1994 using the BROKK machine. Approximately 22,727 kg (50,000 lb) of activated concrete was removed. Figure 32 shows the tasks associated with Phase IV.

In October 1995 the decision was made not to decontaminate to full unrestricted release levels, but to remediate all accessible areas to background levels and render all remaining activity inaccessible. The building sump and associated drains were decontaminated and metal caps were installed over the pipes to seal in contamination where it could not be reached or cleaned. During this time portable HEPA filtration units were used for any activities that could potentially expose personnel to radiological uptake. 


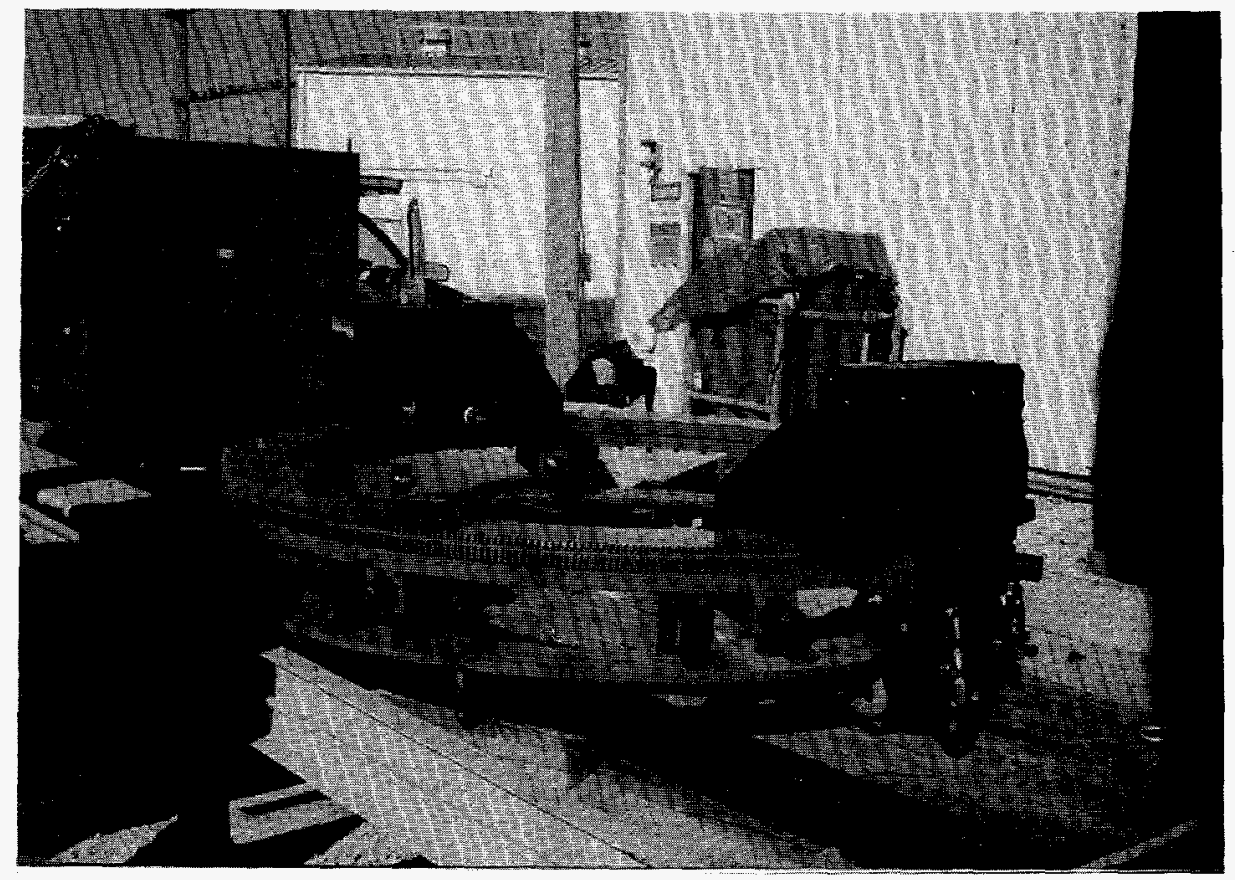

FIGURE 23 Reactor Vessel Cutting Machine (ANL Negative \#20098K, Frame \#21)

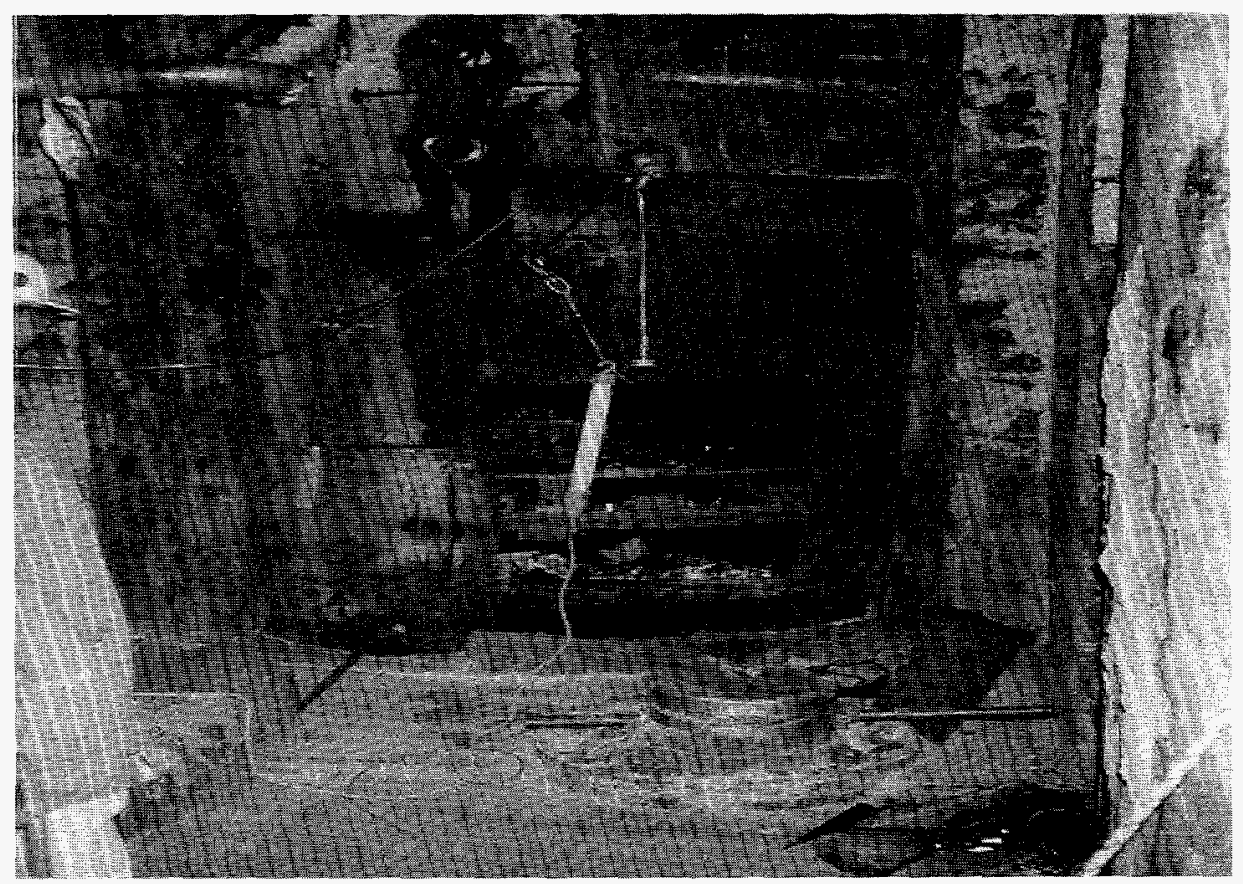

FIGURE 24 View of Vessel Cutting Machine through the Manway Access (ANL Negative \#20098K, Frame \#22) 

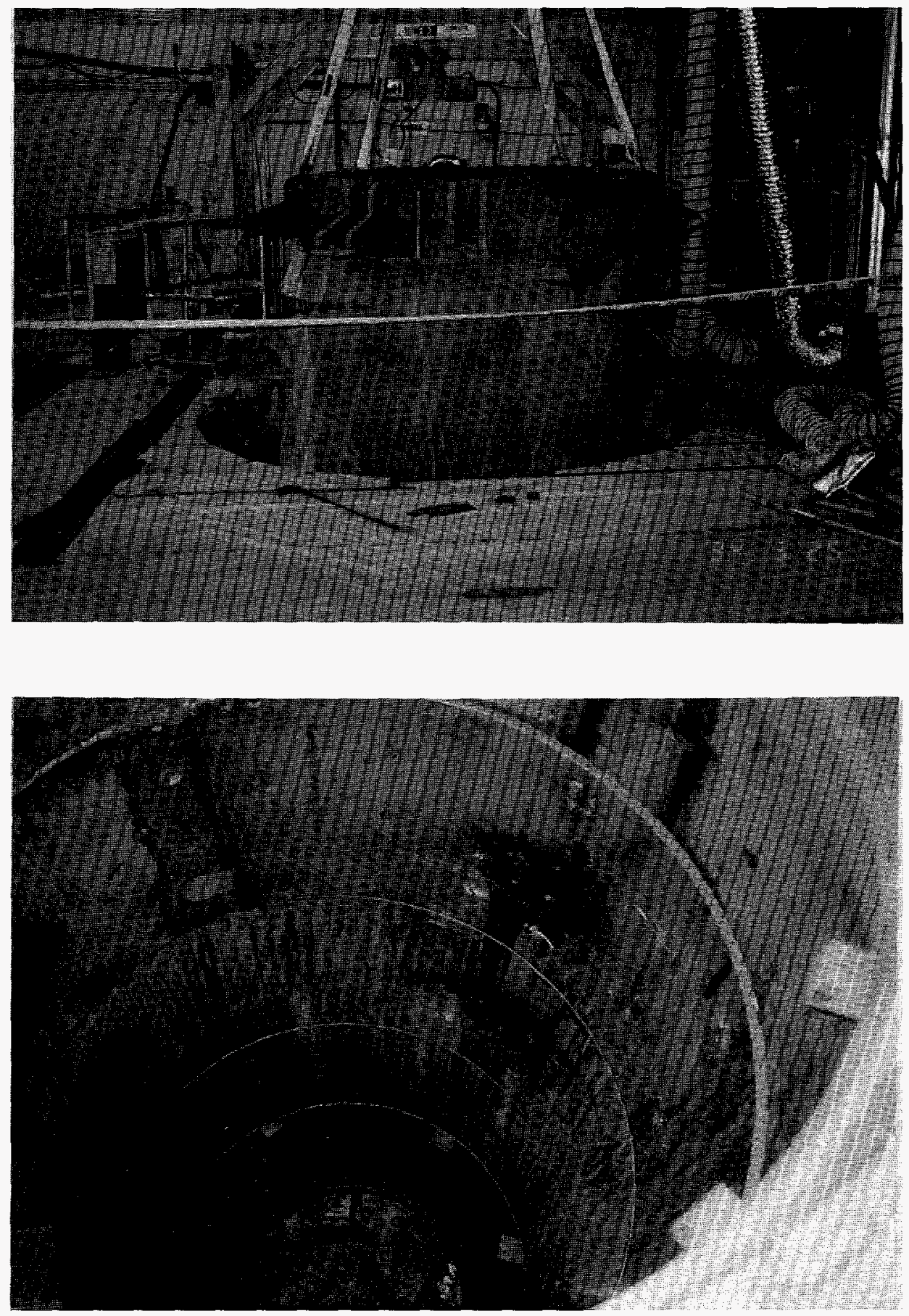

FIGURE 25 Removal of the Top Vessel Section Plus the Remaining Cut Vessel Sections (ANL Negative \#20098K, Frames \#23 and \#24) 

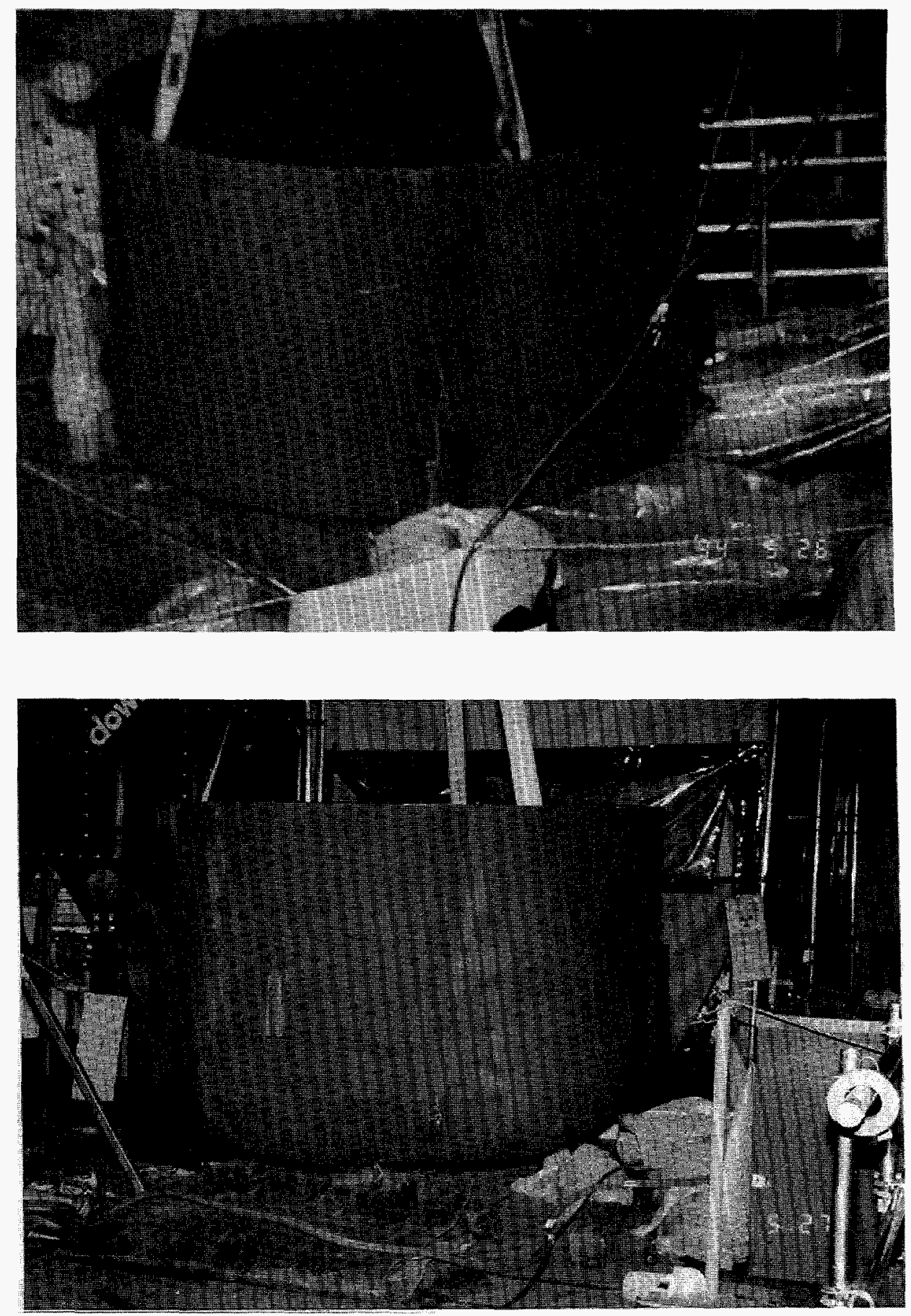

FIGURE 26 Removal of Remaining Vessel Sections (ANL Negative \#20098K, Frames \#25 and \#26) 


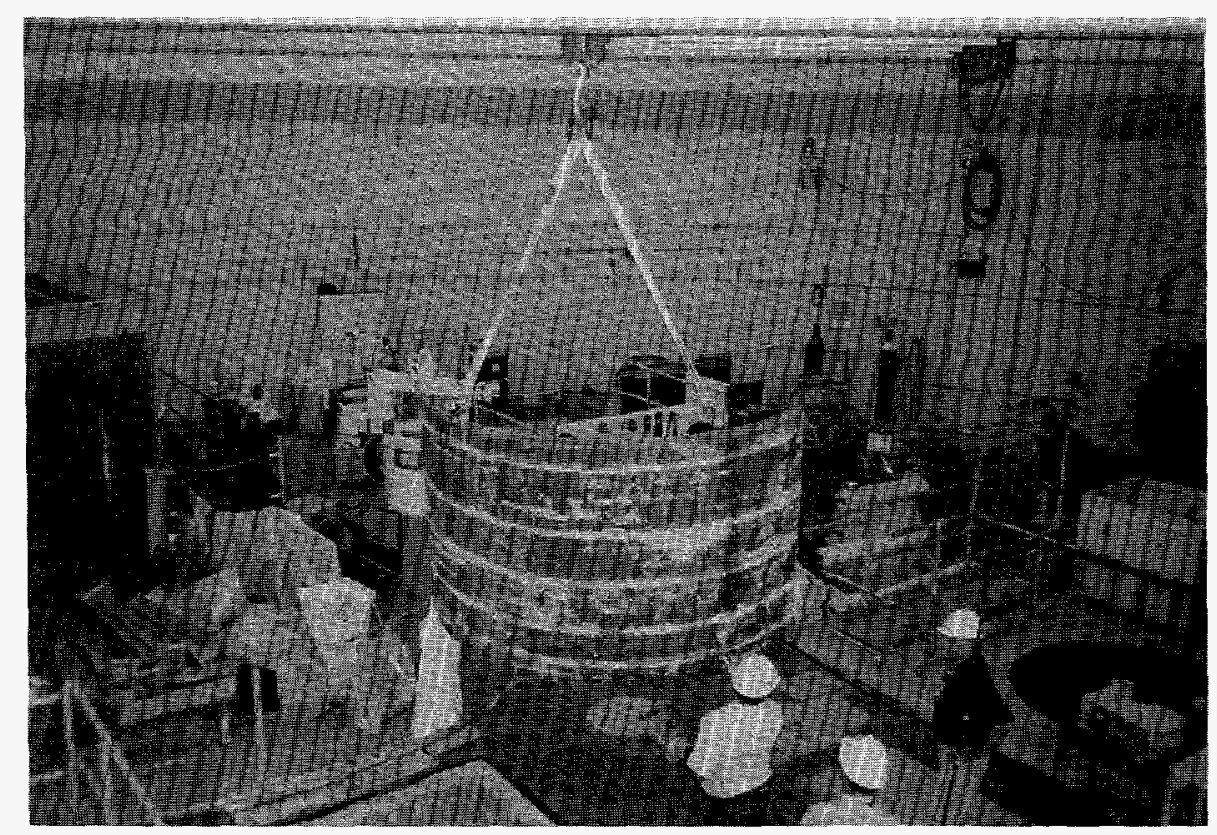

FIGURE 27 Removal of the Reactor Vessel Liner (ANL Negative \#20098K, Frame \#27)

Elevated radiation levels remain in the reactor vessel cavity due to activated concrete. However, a structural analysis of the EBWR biological shield indicated that all concrete would have to be removed to accomplish any additional remediation, i.e., the bioshield would become structurally unsound if additional concrete were removed from the reactor cavity. In November 1995 a meeting was held between DOE and ANL-E representatives in which a list of locations in the EBWR shell containing radiological material above background when the facility was transferred from EM-40 to EM-30 was developed. In all cases, the residual radioactivity to be left in place did not pose an unacceptable risk to the future users of the site when converted to an interim transuranic waste storage facility. DOE, in consultation with ANL-E, has determined that the following items have substantial economic value to the new users of the facility and/or it is not cost effective to decontaminate further or remove the items, particularly because of the new use as an interim transuranic waste storage facility.

The locations labeled at the conclusion of the EBWR D\&D project are listed in the following sections.

\subsubsection{Level 4}

- Fuel pool fuel channel - Probably contaminated, covered

- Fuel pool drain line and overflow drain - Contaminated, both covered 
TABLE 1 Comparisons of the Three Cutting Methods Used for Size Reducing the EBWR Reactor Vessel

\begin{tabular}{|c|c|c|c|}
\hline Cutting Method & Cutting Speeds & Advantages & Disadvantages \\
\hline $\begin{array}{l}\text { WTS Vessel } \\
\text { Cutting Machine } \\
\text { (mechanical). }\end{array}$ & $\begin{array}{l}\text { A total of } 197 \text { " with one } \\
\text { vertical cut over } 4 \text { " deep } \\
\text { was made on the bottom } \\
\text { bowl in } 18 \text { hours for a cut } \\
\text { rate of } 0.18 " / \text { min (most } \\
\text { difficult cut). A total of } \\
1056^{\prime \prime} \text { with } 4 \text { horizontal } \\
\text { cuts } 2.5^{\prime \prime} \text { deep was made } \\
\text { on the remainder of the } \\
\text { vessel in } 22 \text { hours for a cut } \\
\text { rate of } 0.8 " / \text { min. }\end{array}$ & $\begin{array}{l}\text { Due to the presence of stainless } \\
\text { steel wool on the outside of the } \\
\text { vessel a mechanical cutting } \\
\text { method was selected over flame } \\
\text { cutting. This provided a } \\
\text { smokeless, clean cut on the } \\
\text { vessel that generated very little } \\
\text { rad waste. The setup was } \\
\text { relatively easy, and remove } \\
\text { operation was available during } \\
\text { actual cutting operations. }\end{array}$ & $\begin{array}{l}\text { Each large cutting machine is } \\
\text { custom built for each } \\
\text { application. This results in a } \\
\text { large fabrication expense for } \\
\text { the equipment. Trained } \\
\text { operators are required for } \\
\text { operation and hands on } \\
\text { assembly is required during the } \\
\text { setup. }\end{array}$ \\
\hline $\begin{array}{l}\text { Flow Jet High } \\
\text { Pressure } \\
\text { Water/Grit } \\
\text { Cutting System }\end{array}$ & $\begin{array}{l}\text { A total of } 540^{\prime \prime} \text { with } 12 \\
\text { cuts } 2.5^{\prime \prime} \text { deep were made } \\
\text { on a section of reactor } \\
\text { vessel in } 679 \text { minutes for a } \\
\text { cut rate of } 0.795^{\prime \prime} / \mathrm{min} \text {. } \\
\text { These cuts tested the } \\
\text { ability of a water jet } \\
\text { system to segment an } \\
\text { irradiated reactor vessel }\end{array}$ & $\begin{array}{l}\text { The flow jet produces a high } \\
\text { quality cut and can be set up } \\
\text { fairly rapidly after an initial } \\
\text { equipment setup and testing. } \\
\text { When used with a track system } \\
\text { it allows for remote operation } \\
\text { by the operator }\end{array}$ & $\begin{array}{l}\text { The equipment is relatively } \\
\text { expensive and requires trained } \\
\text { operators for setup and } \\
\text { operation. Control of the over } \\
\text { spray is extremely difficult. A } \\
\text { relatively large amount of rad } \\
\text { waste was generated as water } \\
\text { and garnet (grit). Depth of cult } \\
\text { control was not possible as was } \\
\text { evidenced by the holes cut in } \\
\text { the water/grit collection drums } \\
\text { and spray deflector plates }\end{array}$ \\
\hline $\begin{array}{l}\text { Oxygen' } \\
\text { Acetylene Torch }\end{array}$ & $\begin{array}{l}\text { Many cuts were made on } \\
\text { the } 2.5^{\prime \prime} \text { thick reactor } \\
\text { vessel rings segmented } \\
\text { with the WTS vessel } \\
\text { cutting machine, The torch } \\
\text { was mounted on a track } \\
\text { system that allowed cut } \\
\text { rates of up to } 12 " / \mathrm{min} \text {. }\end{array}$ & $\begin{array}{l}\text { The system provided an } \\
\text { inexpensive fast method to size } \\
\text { reduce the reactor vessel rings } \\
\text { into pieces packaged into } \\
\text { acceptable disposal packages. } \\
\text { The equipment was easy to } \\
\text { operate and allowed remote } \\
\text { operation after the setup. }\end{array}$ & $\begin{array}{l}\text { HEPA ventilation and smoke } \\
\text { control were required. The } \\
\text { operator was required to } \\
\text { physically perform a hands on } \\
\text { setup after each cut. Fire watch } \\
\text { and heat stress monitoring was } \\
\text { required during the cutting } \\
\text { operations. }\end{array}$ \\
\hline
\end{tabular}


TABLE 2 EBWR D\&D Project Metal Cutting Methods

\begin{tabular}{|c|c|c|c|}
\hline Cutting Method & Components Cut & Advantages & Disadvantages \\
\hline $\begin{array}{l}\text { PAK } 45 \text { (Dry) Plasma } \\
\text { Arc }\end{array}$ & $\begin{array}{l}\text { Thermal Shields, } \\
\text { Reactor Vessel Lugs }\end{array}$ & $\begin{array}{l}\text { Fast, cuts up to } 4 " \text { thick } \\
\text { Stainless Steel }\end{array}$ & $\begin{array}{l}\text { Requires HEPA ventilation/ containment } \\
\text { for smoke }\end{array}$ \\
\hline $\begin{array}{l}\text { PAK } 45 \text { (Underwater) } \\
\text { Plasma Arc }\end{array}$ & $\begin{array}{l}\text { Core Assembly, } \\
\text { Thermal Shields, } \\
\text { Control Rods }\end{array}$ & $\begin{array}{l}\text { Remote underwater cutting, } \\
\text { smokeless }\end{array}$ & $\begin{array}{l}\text { Requires water treatment for water } \\
\text { quality/clarity, remote handling difficult } \\
\text { without guides of manipulators }\end{array}$ \\
\hline $\begin{array}{l}\text { PAK } 10 \text { (Dry) Plasma } \\
\text { Arc }\end{array}$ & $\begin{array}{l}\text { Steam duct, Feed- } \\
\text { water and Spray } \\
\text { Rings, miscellaneous } \\
\text { Stainless Steel }\end{array}$ & $\begin{array}{l}\text { Fast, cuts up to } 1 " \text { thick } \\
\text { Stainless Steel }\end{array}$ & $\begin{array}{l}\text { Requires HEPA ventilation/containment } \\
\text { for smoke }\end{array}$ \\
\hline $\begin{array}{l}\text { Oxygen/Acetylene } \\
\text { Torch }\end{array}$ & $\begin{array}{l}\text { Reactor Vessel, } \\
\text { Reactor Cavity } \\
\text { Liner, miscellaneous } \\
\text { carbon steel }\end{array}$ & $\begin{array}{l}\text { East to use, inexpensive, } \\
\text { good cut quality when used } \\
\text { with a track system }\end{array}$ & $\begin{array}{l}\text { Requires HEPA ventilation/containment } \\
\text { for smoke }\end{array}$ \\
\hline $\begin{array}{l}\text { Oxygen/Propane } \\
\text { Torch }\end{array}$ & $\begin{array}{l}\text { Miscellaneous } \\
\text { carbon steel }\end{array}$ & Easy to use, inexpensive & $\begin{array}{l}\text { Requires HEPA ventilation/containment } \\
\text { for smoke, does not burn as hot as } \\
\text { acetylene }\end{array}$ \\
\hline $\begin{array}{l}\text { WTS Vessel Cutting } \\
\text { Machine }\end{array}$ & $\begin{array}{l}\text { Reactor Vessel, } \\
\text { Reactor Cavity Liner }\end{array}$ & $\begin{array}{l}\text { Smokeless, limited waste, } \\
\text { remote operation, excellent } \\
\text { cut quality }\end{array}$ & $\begin{array}{l}\text { Expensive (each machine is special } \\
\text { built), requires trained operators, the } \\
\text { setup can be difficult }\end{array}$ \\
\hline $\begin{array}{l}\text { WTS Split Ring } \\
\text { Machines }\end{array}$ & $\begin{array}{l}\text { Reactor Vessel } \\
\text { Nozzles }\end{array}$ & $\begin{array}{l}\text { Smokeless, limited waste, } \\
\text { remote operation, excellent } \\
\text { cut quality }\end{array}$ & $\begin{array}{l}\text { Requires training of operators on } \\
\text { process }\end{array}$ \\
\hline WTS Rail Mill & $\begin{array}{l}\text { Shield Plug Liner, } \\
\text { Reactor Cavity Liner }\end{array}$ & $\begin{array}{l}\text { Easy to use, quick setup, } \\
\text { smokeless, excellent cut } \\
\text { quality }\end{array}$ & $\begin{array}{l}\text { Requires trained operators, welding } \\
\text { required during the setup on vertical and } \\
\text { overhead applications }\end{array}$ \\
\hline $\begin{array}{l}\text { Flow Water Jet } \\
\text { System }\end{array}$ & Reactor Vessel & $\begin{array}{l}\text { Smokeless, relatively easy } \\
\text { setup after initial } \\
\text { installation, excellent cut } \\
\text { quality, relatively remote } \\
\text { operation }\end{array}$ & $\begin{array}{l}\text { Messy, high waste water generation, } \\
\text { unable to control depth of cut (cut } \\
\text { through splash plates and water } \\
\text { collection drums), requires trained } \\
\text { operators, extremely high pressure } \\
\text { water, elaborate containment and water } \\
\text { collection/filtration equipment required, } \\
\text { expensive }\end{array}$ \\
\hline $\begin{array}{l}\text { Pipe Cutters, Sawz- } \\
\text { alls, porta-band saws }\end{array}$ & $\begin{array}{l}\text { Miscellaneous } \\
\text { carbon steel pipe and } \\
\text { metal }\end{array}$ & $\begin{array}{l}\text { Inexpensive, easy to use, } \\
\text { readily available, } \\
\text { smokeless }\end{array}$ & $\begin{array}{l}\text { Limited applications, non-remote } \\
\text { operation }\end{array}$ \\
\hline
\end{tabular}




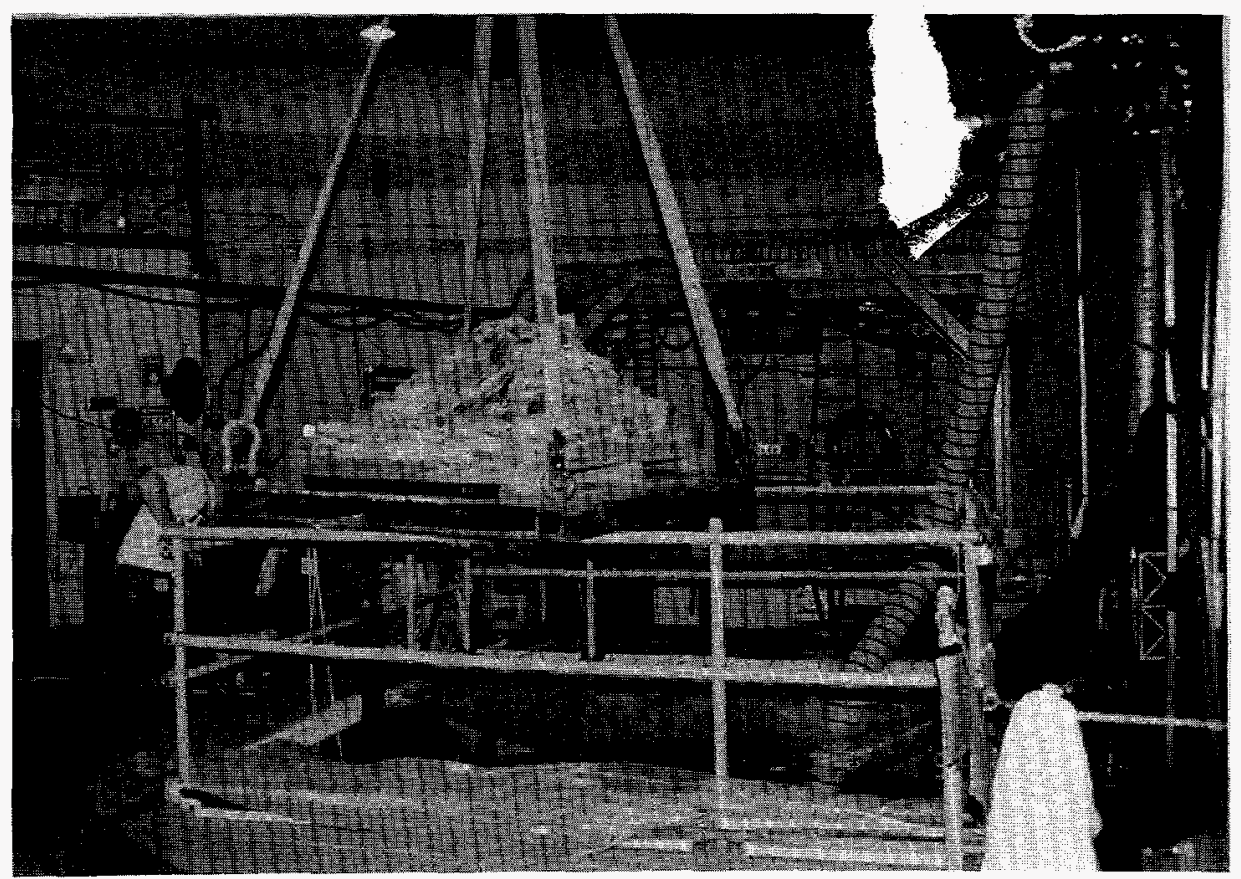

FIGURE 28 Removal of Potentially Activated Lead (ANL Negative \#20098K, Frame \#28)

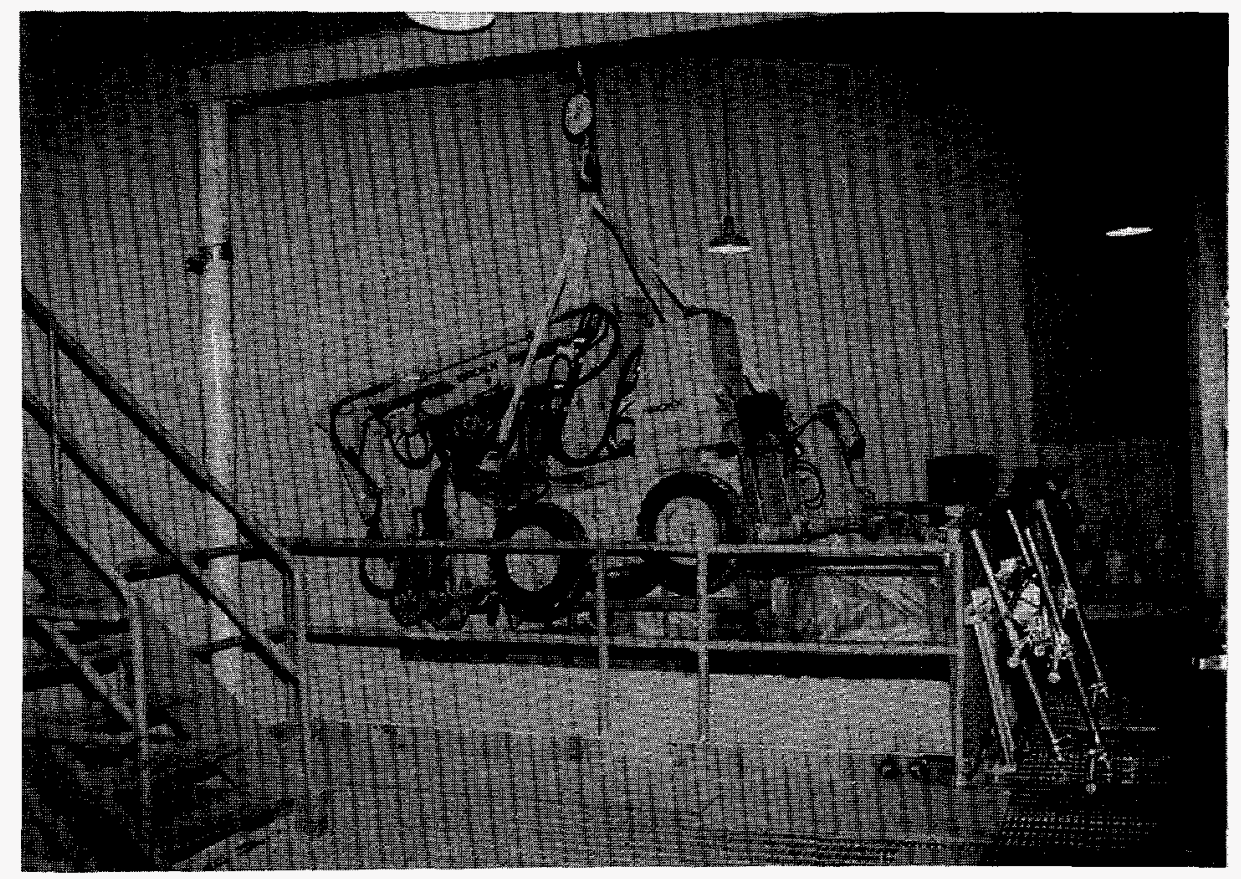

FIGURE 29 The BROKK Machine Being Loaded into the EBWR (ANL Negative \#20098K, Frame \#29) 


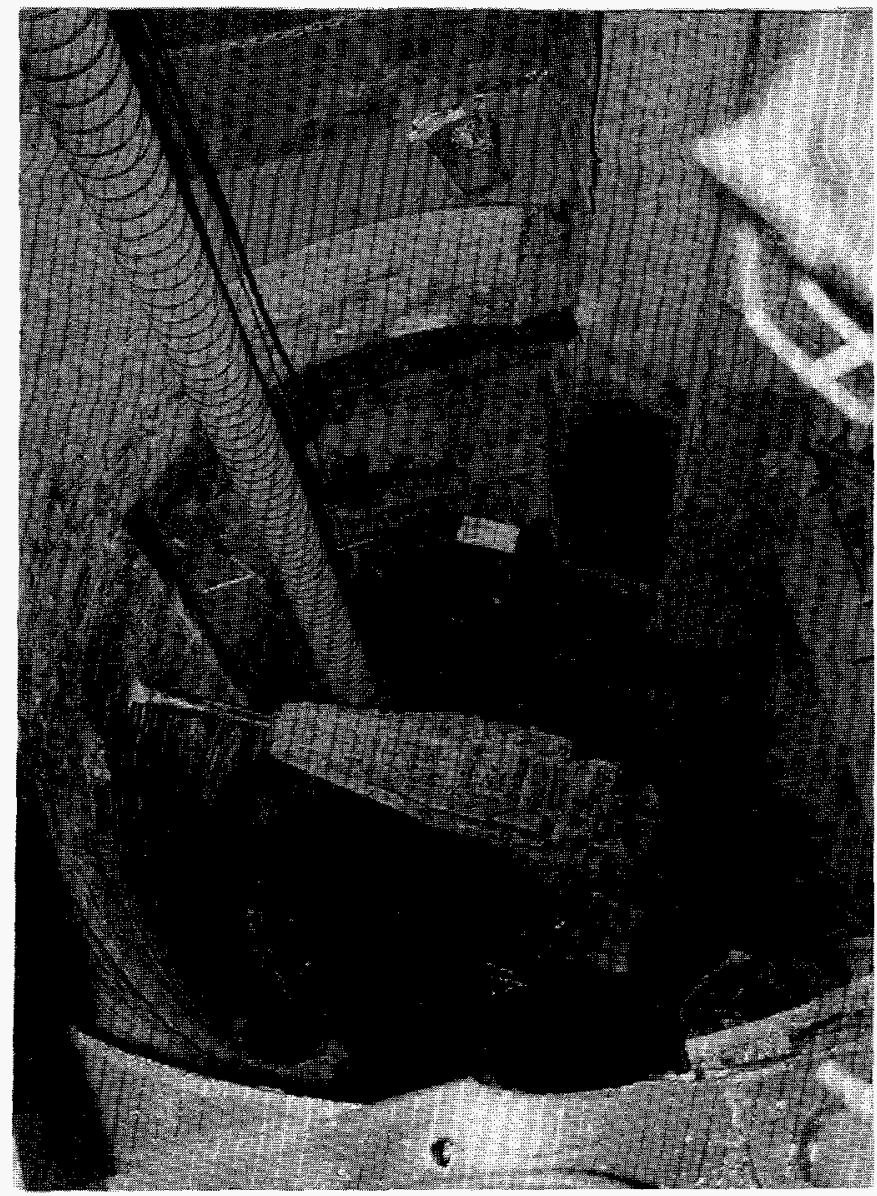

FIGURE 30 BROKK Machine Dismantling the Concrete Bioshield (ANL Negative \#20098K, Frame \#30)

- Fuel pool area pipe pit - Contaminated in pipes, covered

- Shell access control area, pipe in floor (11/2" diameter) - Contaminated, covered

- Level 4 upper wall pipe chase (10" diameter) - Contaminated, capped

- Elevator motor internals - Potentially contaminated, sealed except during maintenance

- Polar crane motor internals - Potentially contaminated, sealed except during maintenance

- Polar crane block, cable, and cable spool - Potentially contaminated, currently inaccessible 


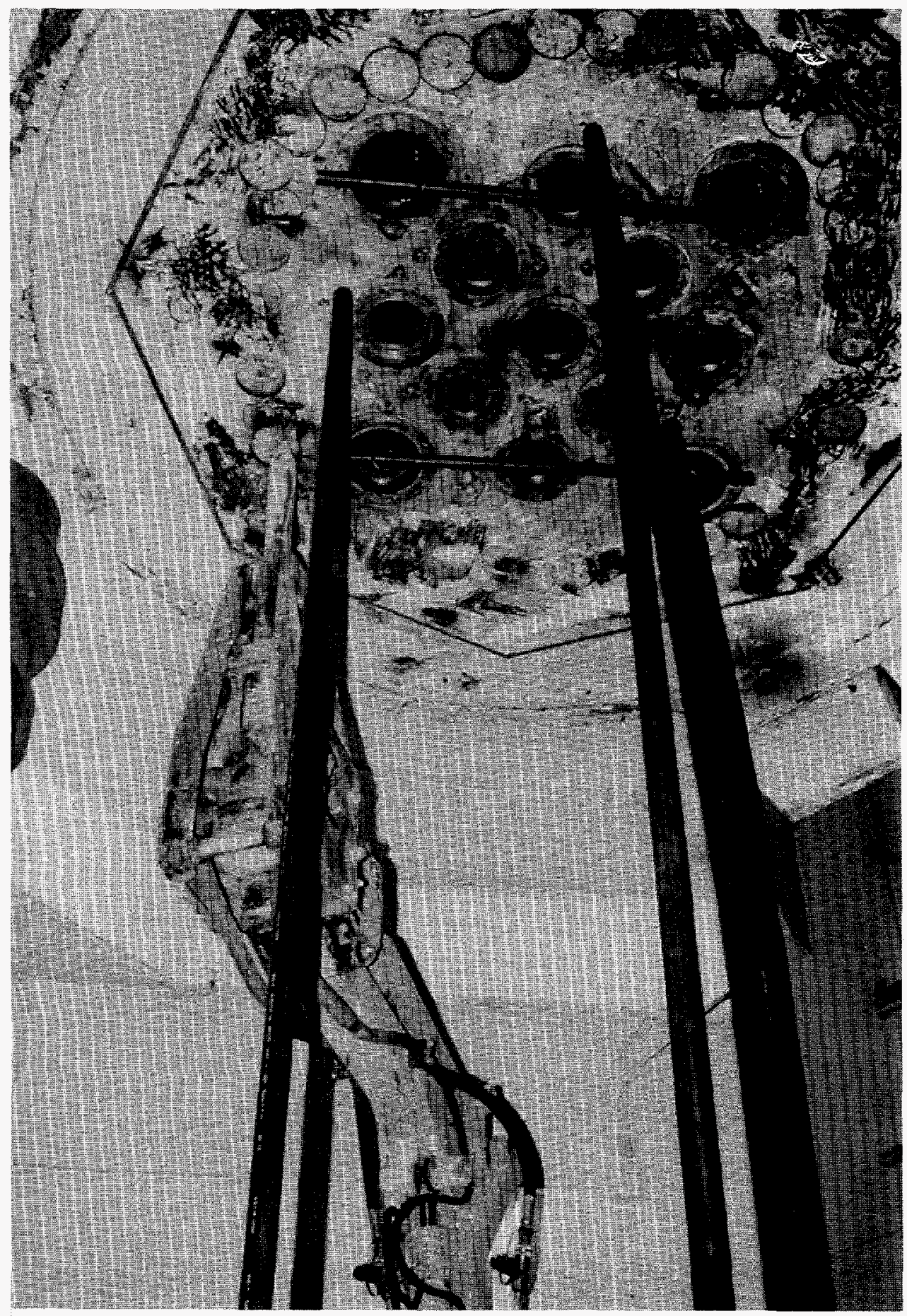

FIGURE 31 The BROKK Machine Removing the Lower Shield Plug of the Reactor (ANL Negative \#20098K, Frame \#31) 


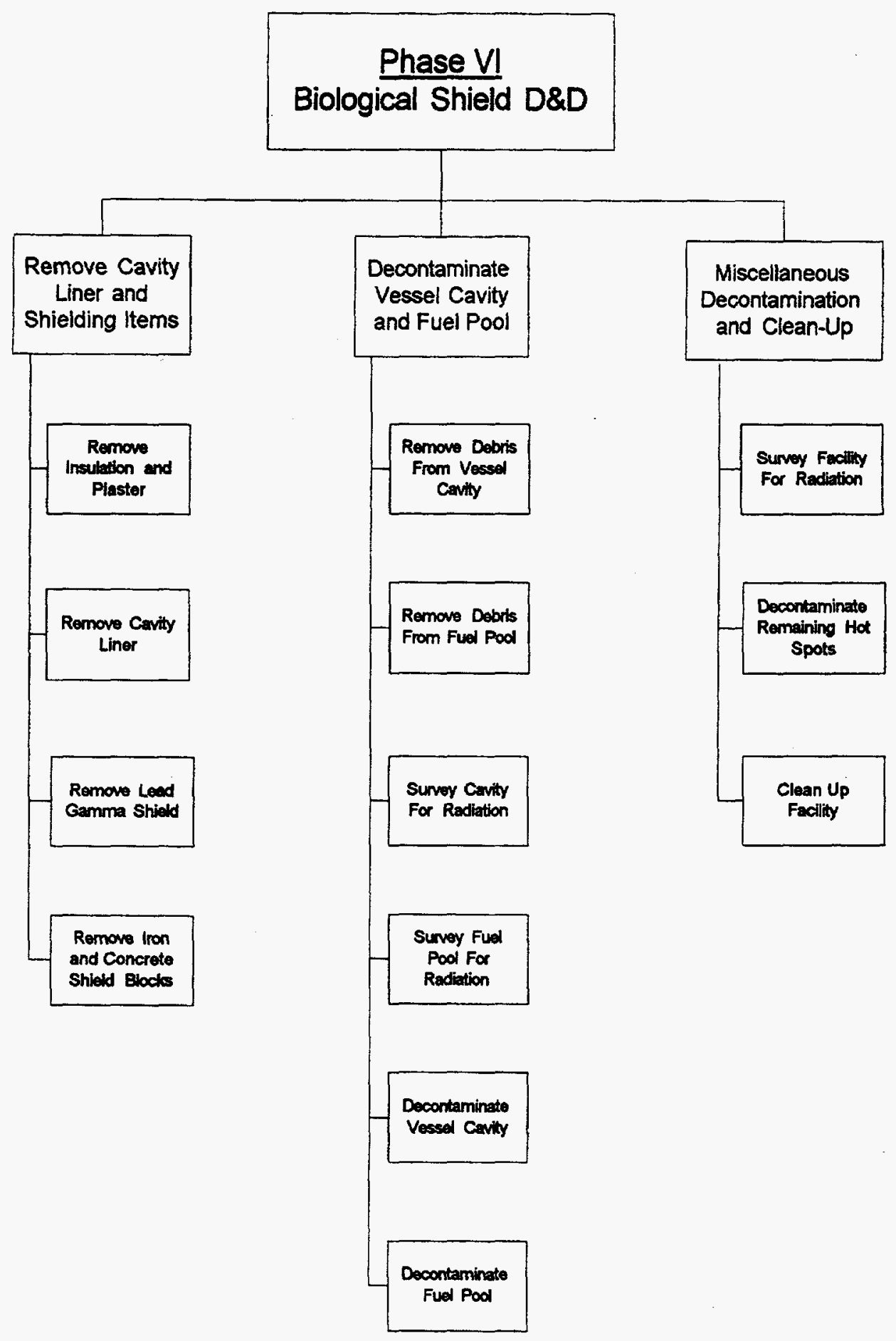

FIGURE 32 EBWR D\&D Project, Phase IV - Biological Shield 


\subsubsection{Level 3}

- Building 331/EBWR shell Level 3 pipe (21/2" diameter) - Contaminated, capped

- Air compressor internals - Potentially contaminated, sealed except during maintenance

\subsubsection{Level 1}

- Embedded drain lines to the sump - Contaminated, capped

- $\quad$ RT vent line ( $3^{\prime \prime}$ diameter) - Contaminated, capped

\subsubsection{Multiple Levels}

- Bioshield cavity - Activated concrete, sealed

- Elevator shaft, pit, and underside of the car - Contaminated, sealed except during maintenance

A final release survey completed in December 1995, confirmed that residual radioactivity in accessible areas of the EBWR facility was at or below background levels. ANL-E HP confirmed ALARON's results with a verification survey completed in January 1996.

\subsection{PROJECT CLOSEOUT}

Project closeout activities included closing out all open Radiation Work Permits (RWPs) and submitting results to the appropriate divisions. All final worker dose records were archived by ESH-HP. ALARON demobilized and removed all temporary housing, equipment, etc. off site. All waste was removed from the facility and disposed of appropriately. Figure 33 shows the tasks associated with project closeout. Figures 34 and 35 show the end condition of the EBWR facility at project closeout. Figure 36 and 37 show the metal cap placed over the reactor cavity, and Figure 36 shows the underside of the reactor cavity from the Level 1 (Basement). Figure 37 shows the gridded and surveyed Level 1. Figures 38 and 39 show the gridded and surveyed fuel pool and sump, respectively.

The EBWR D\&D project report was developed, summarizing the D\&D activities and the results. This final report documents the project's activities and concludes the EBWR D\&D project. 


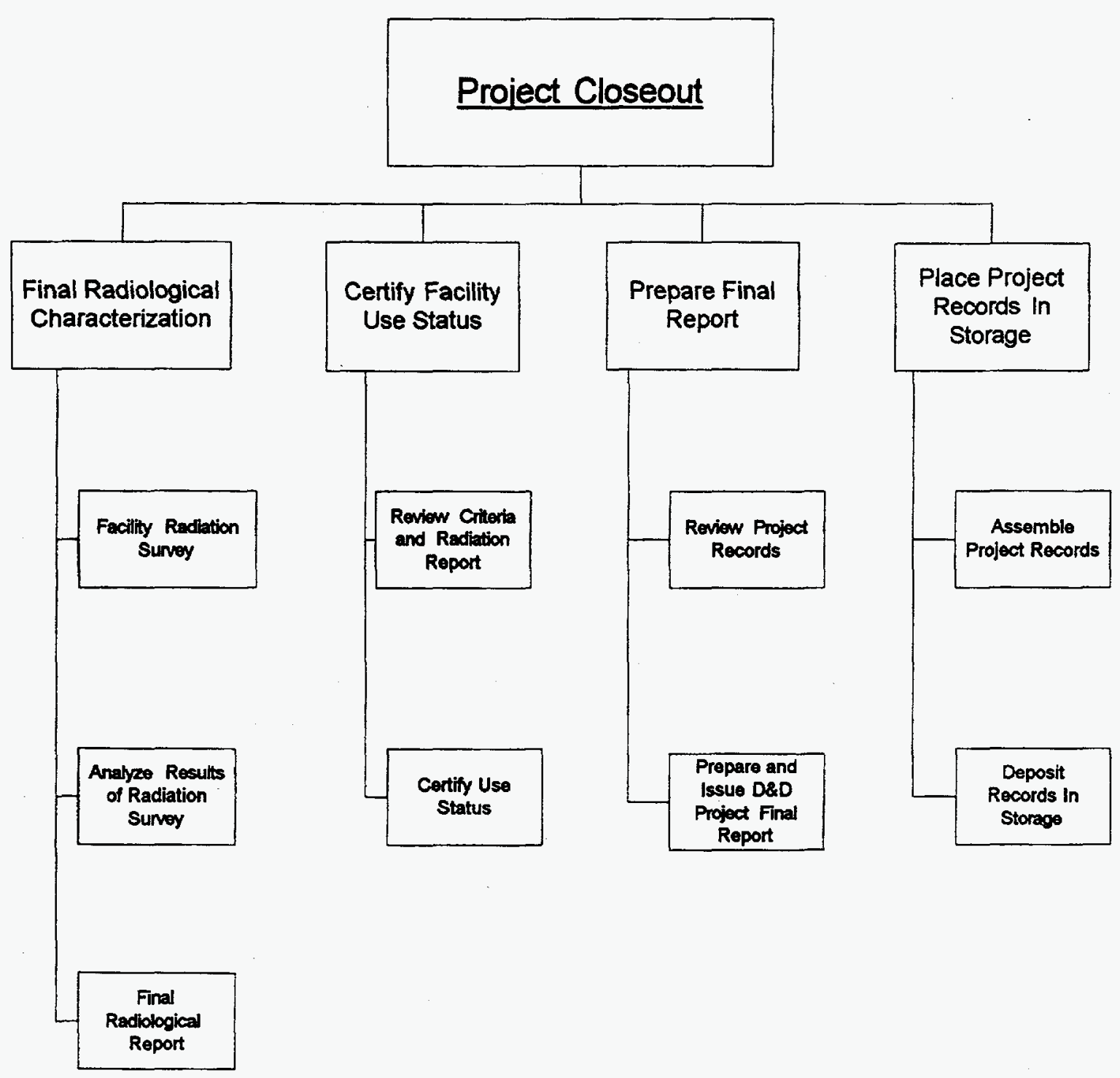

FIGURE 33 EBWR D\&D Project, Phase V - Project Closeout 


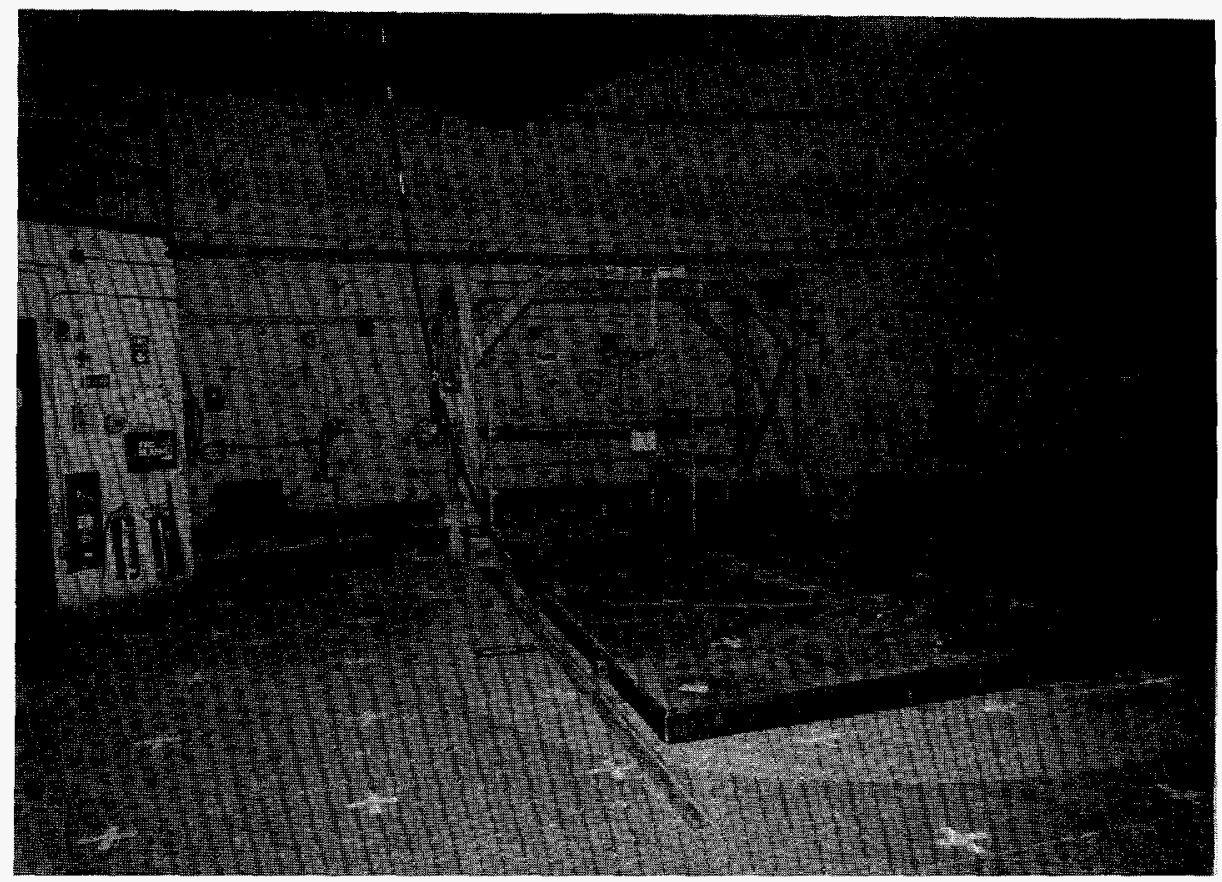

FIGURE 34 EBWR Reactor Cavity, 4th Level, after Project Closeout (ANL Negative \#21023K Frame \#4)

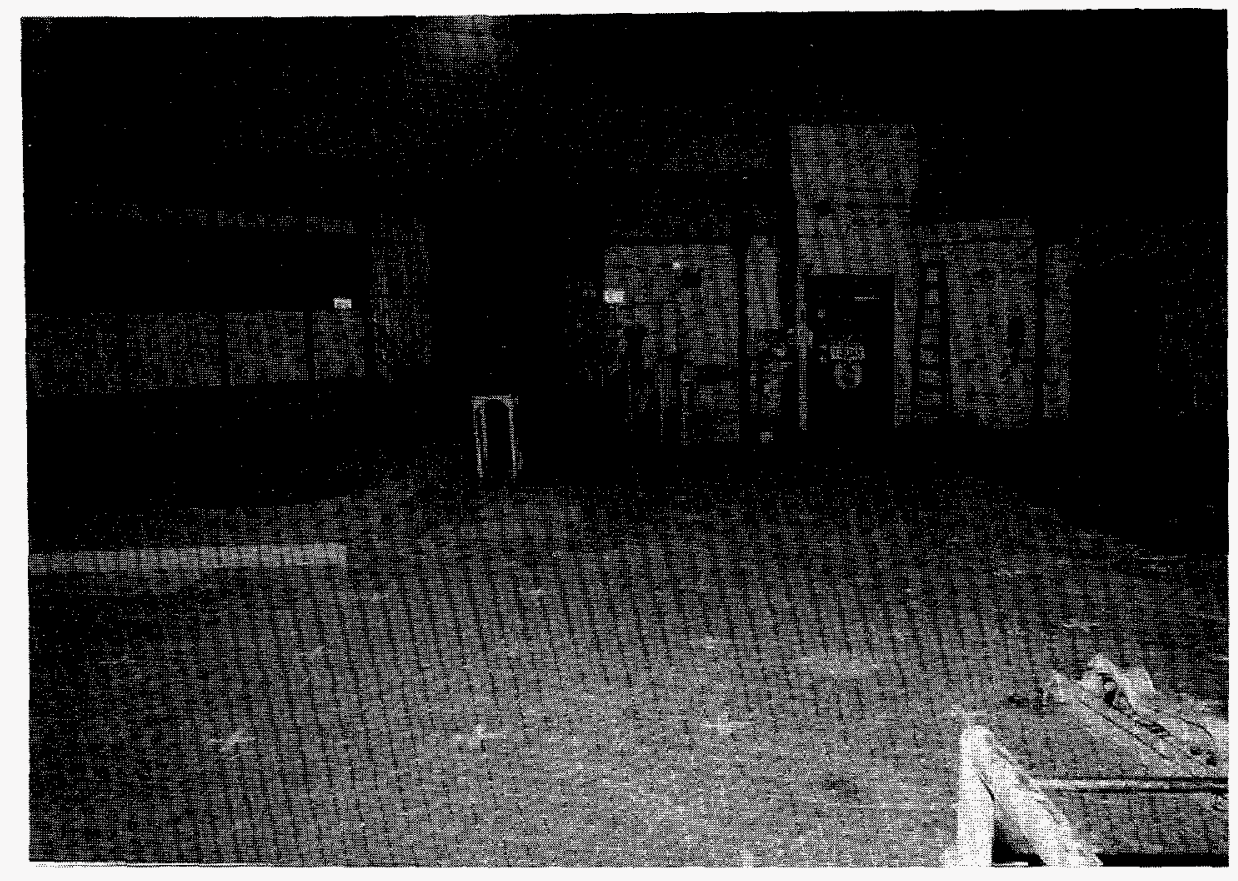

FIGURE 35 EBWR, 4th Level, after Project Closeout (ANL Negative 21023K, Frame \#6) 


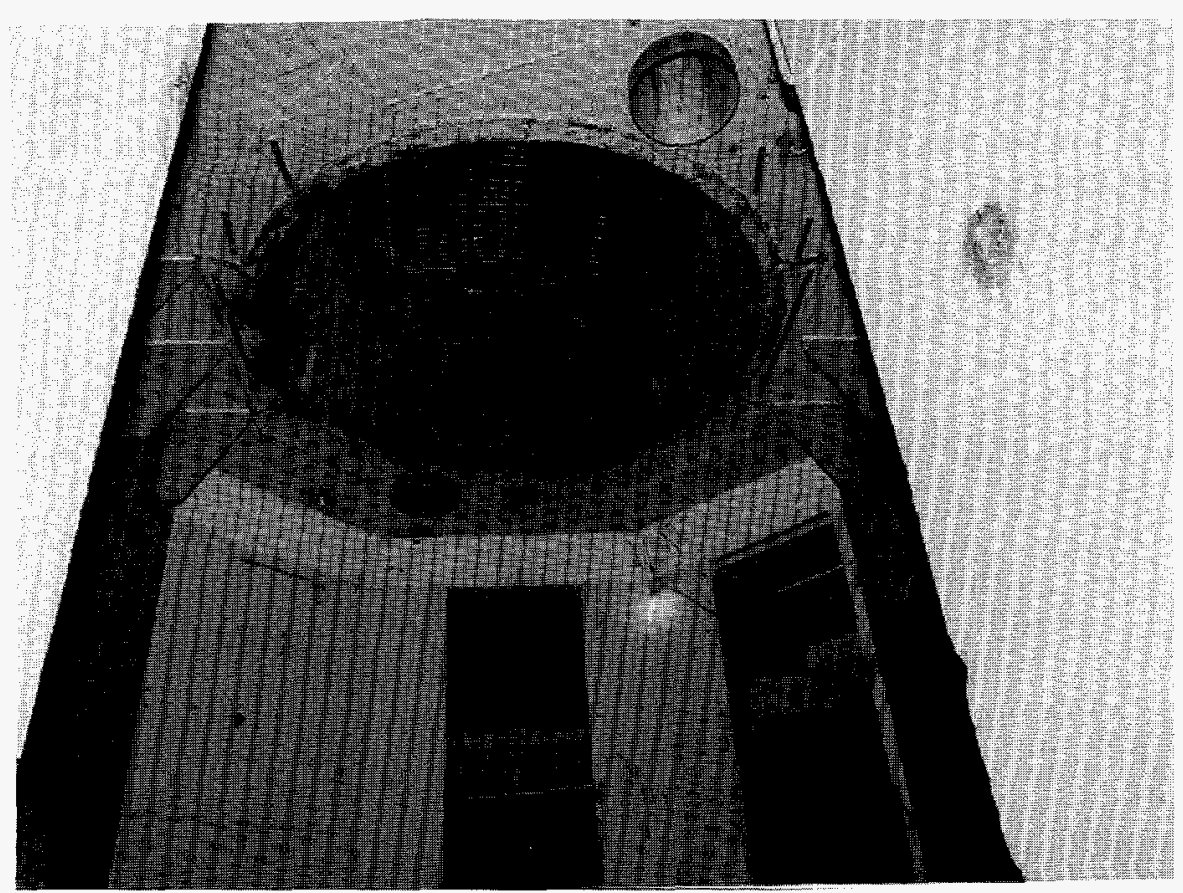

FIGURE 36 EBWR Reactor Cavity, 1st Level, after Project Closeout (ANL Negative \#21023K, Frame \#19)

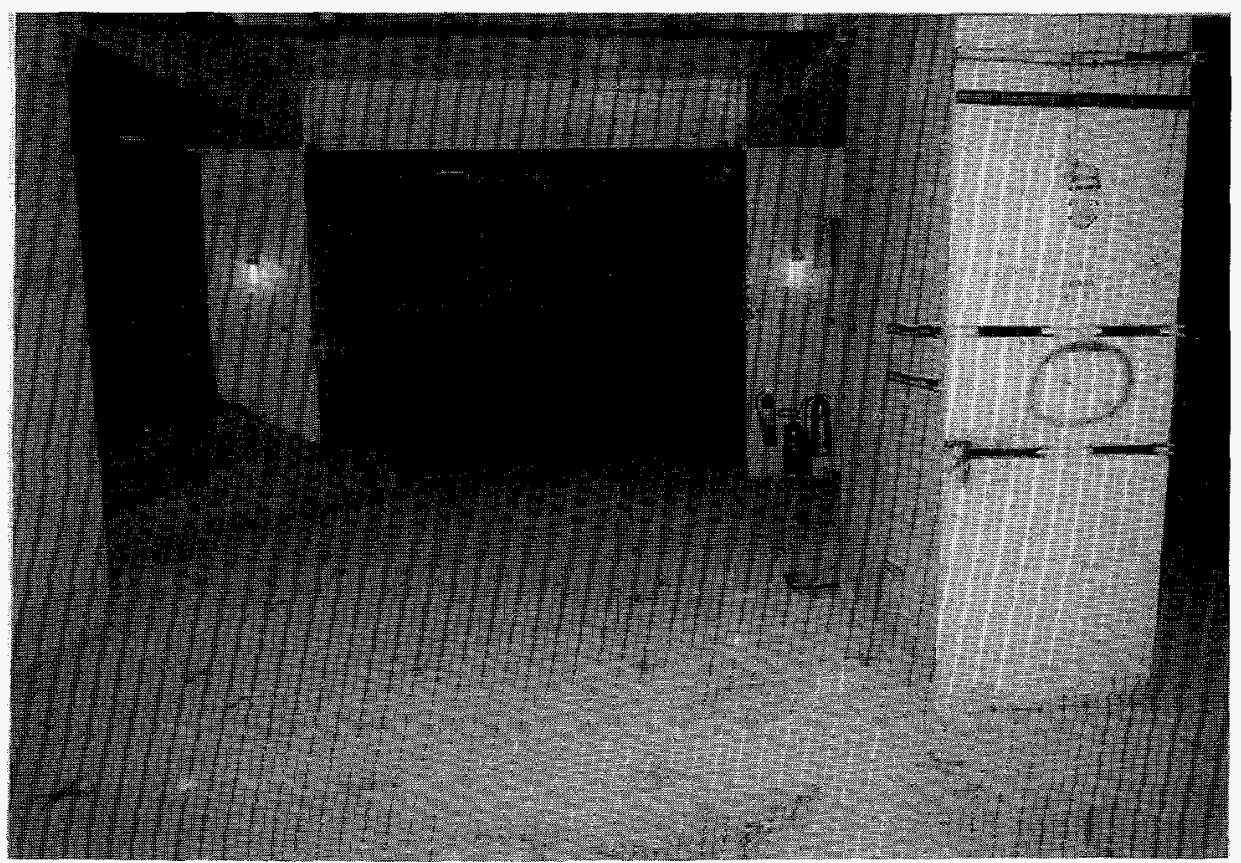

FIGURE 37 EBWR, 1st Level, after Project Closeout (ANL Negative \#21023K, Frame \#17) 


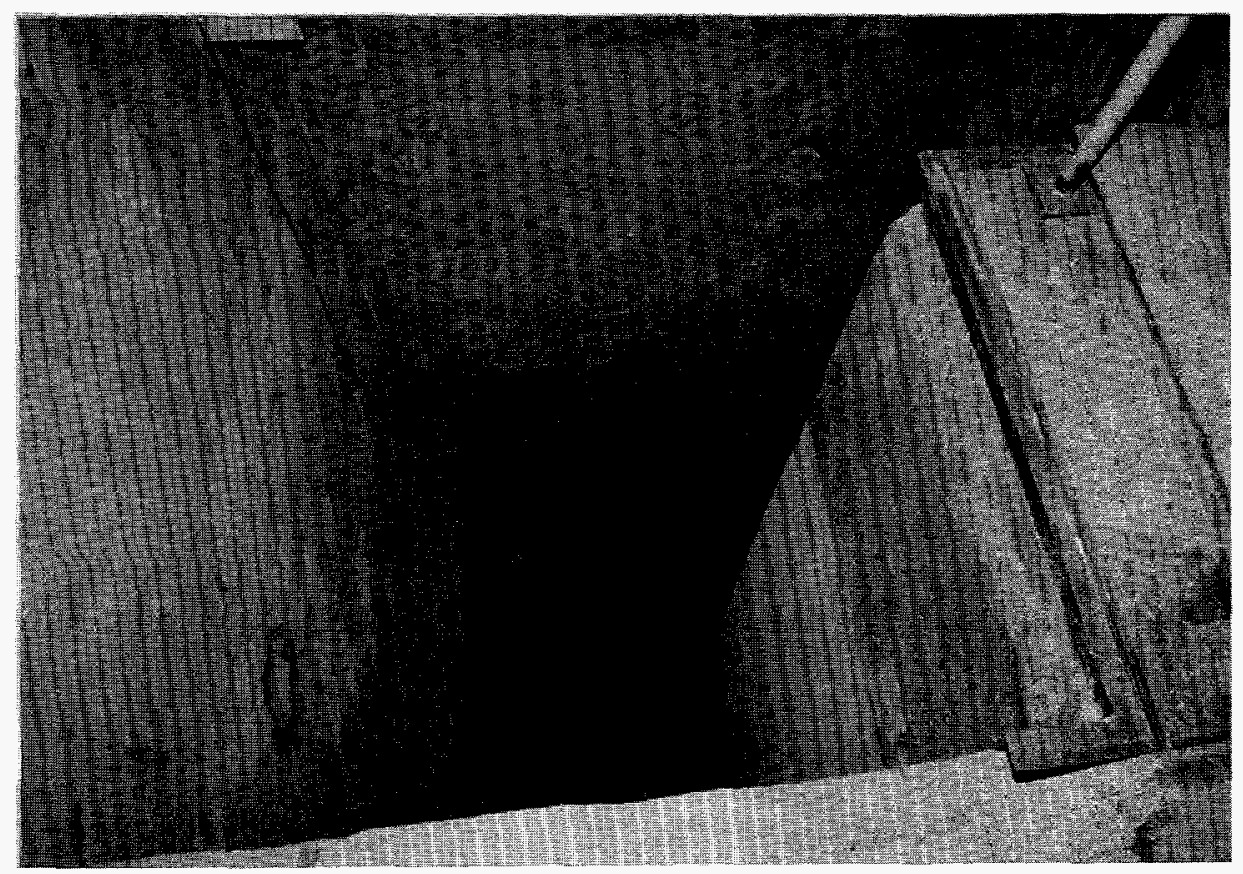

FIGURE 38 EBWR Fuel Pool after Project Closeout (ANL Negative \#21023K, Frame \#8)

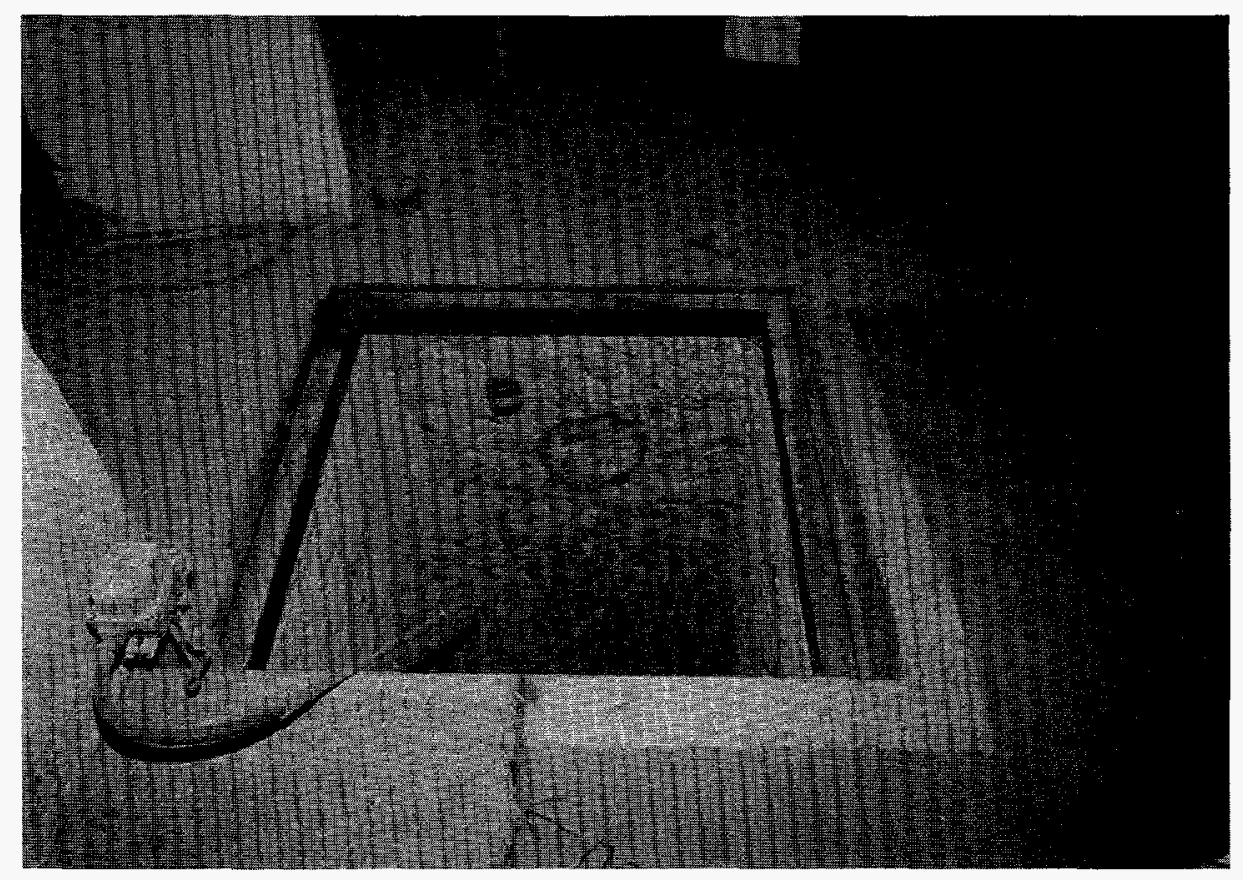

FIGURE 39 EBWR Sump after Project Closeout (ANL Negative \#21023K, Frame \#23) 


\section{POST-DECOMMISSIONING RADIOLOGICAL SURVEY}

ALARON developed a work package containing the methodology and procedures for the post D\&D radiological survey. Procedures developed for the EBWR D\&D project and were reviewed and approved by the ANL-E HP and appropriate review groups.

\subsection{FINAL SURVEY OBJECTIVES}

The purpose of the final status survey was to show that the radiological conditions in the accessible areas of the EBWR facility satisfy the ANL-E unrestricted release guidelines presented in DOE Order 5400.5, "Radiation Protection of the Public and the Environment" and ANL-E Health Physics Procedures. Areas of contamination above releasable levels were rendered inaccessible by using wooden or concrete plugs and bolted metal caps (see Section 5.5). Survey units included the accessible areas of these plugs and caps.

\subsubsection{Project Objectives}

The specific objectives of the release survey included ensuring:

- Average surface contamination levels for each survey unit were within the authorized values.

- Small areas of residual activity (hot-spots) did not exceed three times the guideline value. The average activity within the $1 \mathrm{~m}^{2}$ area containing the hot spot was within the guideline.

- Reasonable efforts were made to clean up removable activity, and removable activity did not exceed the guideline value.

- Exposure rates in occupiable locations were less than 5 microroengten $(\mu \mathrm{R}) / \mathrm{hr}$ above background. Exposure levels were measured at 1 meter from floor/lower wall surfaces and are averaged over floor areas, not to exceed $10 \mathrm{~m}^{2}$. The maximum exposure rate at 1 meter did not exceed $10 \mu \mathrm{R} / \mathrm{hr}$ above background.

- The average and maximum dose rates associated with surface contamination resulting from beta-gamma emitters did not exceed $2 \mu \mathrm{Gy}(0.2 \mathrm{mrad})$ per hr at $1 \mathrm{~cm}$. 
- Reasonable efforts were made to identify and remove all activated structural material.

- Reasonable efforts were made to identify and remove contaminated paint or coatings on EBWR shell surfaces.

\subsubsection{Unrestricted Release Criteria}

The release criteria applicable to the EBWR shell were based on DOE Order 5400.5 and ANL-E Health Physics Procedures. Based on the combination of radiological contaminants present within the EBWR shell, the surface contamination guideline values for beta-gamma contamination were:

$83 \mathrm{~Bq}(5000 \mathrm{dpm}) / 100 \mathrm{~cm}^{2}$, fixed and removable, average over $1 \mathrm{~m}^{2}$;

$250 \mathrm{~Bq}(15,000 \mathrm{dpm}) / 100 \mathrm{~cm}^{2}$, maximum fixed and removable; and

$17 \mathrm{~Bq}(1000 \mathrm{dpm}) / 100 \mathrm{~cm}^{2}$, removable contamination including tritium.

Surface contamination guidelines for transuranic alpha contamination were:

$1.67 \mathrm{~Bq}(100 \mathrm{dpm}) / 100 \mathrm{~cm}^{2}$, fixed and removable, average over $1 \mathrm{~m}^{2}$;

$5 \mathrm{~Bq}(300 \mathrm{dpm}) / 100 \mathrm{~cm}^{2}$, maximum fixed and removable; and

$0.3 \mathrm{~Bq}(20 \mathrm{dpm}) / 100 \mathrm{~cm}^{2}$, removable contamination.

Exposure rates in occupiable locations were reduced to less than $5 \mu \mathrm{R} / \mathrm{hr}$ above background. Exposure levels were measured at 1 meter from floor/lower wall surfaces and averaged over floor areas (not exceeding $10 \mathrm{~m}^{2}$ ). Exposure rates at 1 meter did not exceed $10 \mu \mathrm{R} / \mathrm{hr}$ above background at any location (i.e., upper walls and ceiling).

\subsection{FINAL SURVEY APPROACH}

\subsubsection{Definitions}

Locations within the EBWR facility were divided into affected or unaffected survey units. These are defined as follows:

Affected Area - Areas that have potential radioactive contamination at levels greater than $25 \%$ of the applicable radionuclide specific guideline value based on past or preliminary radiological surveillance. Any area originally classified as unaffected where radionuclide 
specific contamination levels exceed $25 \%$ of the guideline level was reclassified as affected.

Unaffected Area - All areas not classified as affected. These areas did not contain residual radioactivity.

Survey Unit - A division of survey area that had similar contamination and deposition patterns (e.g., floors, walls, horizontal surfaces). The maximum survey unit size was limited to approximately $100 \mathrm{~m}^{2}$ for affected areas and no survey unit included both affected and unaffected areas.

\subsubsection{Potential Contaminants}

Based on knowledge of site operations (including fuel pool size reduction operations), preliminary fuel pool water and filter analyses, and bioshield concrete analyses, the potential contaminants in the EBWR shell were identified as follows:

\section{Radionuclide Location/Remarks}

$\begin{array}{ll}\mathrm{H}^{3} & \text { Fuel Pool Surfaces } \\ \mathrm{Na}^{22} & \text { Bioshield Concrete } \\ \mathrm{K}^{40} & \text { Bioshield Concrete \& Pool Surfaces } \\ \mathrm{Mn}^{54^{*}} & \text { Fuel Pool Surfaces } \\ \mathrm{Fe}^{55^{*}} & \text { Bioshield Concrete \& Pool Surfaces } \\ \mathrm{Co}^{57} & \text { Bioshield Concrete } \\ \mathrm{Co}^{60} & \text { Bioshield Concrete \& Pool Surfaces } \\ \mathrm{Fe}^{60} & \text { Bioshield Concrete } \\ \mathrm{Ni}^{59^{*}} & \text { Fuel Pool Surfaces } \\ \mathrm{Ni}^{63 *} & \text { Fuel Pool Surfaces } \\ \mathrm{Sr} / \mathrm{Y}^{90} & \text { Fuel Pool Surfaces } \\ \mathrm{Ag} & \text { Bioshield Concrete } \\ \mathrm{Cd} & \text { Bioshield Concrete } \\ \mathrm{Sb}^{109} & \text { Bioshield Concrete \& Pool Surfaces } \\ \mathrm{Cs}^{137} & \text { Fuel Pool Surfaces } \\ \mathrm{Eu}^{152} & \text { Bioshield Concrete } \\ \mathrm{Eu}^{154} & \text { Bioshield Concrete } \\ \mathrm{Pb}^{210} & \text { Bioshield Concrete } \\ \mathrm{Pu}^{238^{* *}} & \text { Fuel Pool Surfaces } \\ \mathrm{Pu}^{239^{* *}} & \text { Fuel Pool Surfaces }\end{array}$




$$
\begin{array}{ll}
\mathrm{Pu}^{240^{* *}} & \text { Fuel Pool Surfaces } \\
\mathrm{Am}^{241} & \text { Fuel Pool Surfaces }
\end{array}
$$

Note: * Denotes radionuclides that are difficult to detect with field instrumentation. The relative contribution of these radionuclides to the total activity present in contamination is expected to be low compared to easily detectable radionuclides.

** Denotes trace quantities.

The final survey, including instrumentation selection, was designed such to identify these isotopes in quantities below the guideline values at the $95 \%$ confidence level. This methodology is described below.

\subsubsection{General Survey Plan}

Initial classification of areas regarding contamination potential was based on radiological data and core borings, and changed if necessary as the final status survey and associated sampling progressed. Radiological data indicated that the fuel pool and associated piping, sumps etc. were affected areas where the guideline levels indicated in Section 6.1.1 were applicable. In addition, core samples from the reactor cavity concrete indicated the presence of activation products leading to and affected area classification. Radiological surveillance during decommissioning activities also indicated that the fourth level of the shell was affected due to the presence of $\mathrm{Co}^{60}$ in surface dust. The following shell levels (floor and lower walls up to 2 meters) were defined as affected areas within the EBWR shell:

- $\quad$ Level 4 (222.6 m (730 ft) elevation);

- Platform level (219.0 m (718.5 ft) elevation, northeast quad);

- $\quad$ Level 3 (217.4 m (713 ft) elevation);

- Platform levels (215.7 m (707.5 ft) elevation, NE and NW quad);

- Level 2 (212.2 m (696 ft) elevation);

- $\quad$ Level 1 (207.9 m (682 ft) elevation);

- Sump below Level 1;

- Fuel pool and associated piping; and

- Reactor cavity concrete. 
Each affected area was divided into quadrants (northeast, southeast, northwest, southwest) as necessary to ensure that affected area survey units were less than $100 \mathrm{~m}^{2}$. The fuel pool and reactor cavity were divided vertically into two and four quadrants respectively. Upper walls and overhead ceilings or beams associated with each level specified above were unaffected areas.

At a minimum, the floors and lower walls of affected areas received $100 \%$ coverage during the final status survey. The survey measurements for surface activity consisted of surface scans, direct measurements, and measurements of removable activity for potentially present isotopes. Locations of areas of elevated activity were identified and direct measurements were made to define their extent and activity levels. Residual activity that exceeded the guideline criteria in any contiguous $1 \mathrm{~m}^{2}$ area or survey unit was remediated until these unrestricted release conditions were satisfied.

Metal floor grating and underlying support structures were scanned and surveyed for total and removable contamination. Upper walls, ceilings, and overhead surfaces classified as affected areas were surveyed in the same manner as floors and lower walls. A minimum of 30 measurement locations on vertical and horizontal surfaces with the highest potential of residual radioactive material were selected in unaffected areas. If these measurements indicated residual activity was greater than $25 \%$ of the guideline value the area was reclassified as affected and the above survey methodology was applied.

To assure reasonable coverage of upper surfaces above affected areas, an average of at least one measurement location per $20 \mathrm{~m}^{2}$ of upper wall and overhead surface area was selected. At each location the immediate area was scanned to identify the presence of any elevated activity levels, followed by the measurement. If scans and measurements indicated residual activity exceeding $25 \%$ of the applicable guideline, the area was evaluated for reclassification as an affected area.

The floors and lower walls of unaffected areas such as the EBWR Attic (769' elevation) received $10 \%$ coverage during surface scanning and at least one measurement for total and removable contamination per $50 \mathrm{~m}^{2}$ surface area.

\subsection{REFERENCE GRID SYSTEM}

A reference grid system was established for the following purposes:

- To facilitate systematic selection of measuring and sampling locations.

- To provide a mechanism for referencing a measurement or sample back to a specific location so that a survey point can be relocated.

- To provide a convenient means for determining average activity levels. 
A grid consisted of a system of intersecting lines referenced to a fixed site location or benchmark that divided the survey location into squares. Typically, these squares were one square meter in affected areas. However, due to the various survey surface types, some grids were smaller than one square meter or a shape other than square.

Gridding was limited to the floor and lower ( 2 meter height) walls of the shell. Survey locations were referenced to the grid system using a survey unit number and alphanumeric identifier; surveys of ungridded surfaces were referenced to the floor grid or to prominent building features and the survey unit number.

\subsection{SURVEY INSTRUMENTATION}

\subsubsection{Instrument Selection}

Table 3 lists the instrumentation used during the final survey of the EBWR. Included are the instruments and detectors used, background calculations, instrument efficiency $(4 \pi)$, and detection Minimum Detectable Activity (MDA).

\subsubsection{Determination of Counting Times}

Minimum counting times for background determinations and counting times for measurement of total and removable beta-gamma and alpha contamination will be chosen to provide MDA that is less than or equal to approximately $25 \%$ of the release guideline levels in Section 6.1.1. MDAs for total and removable beta-gamma and alpha contamination is determined using the Equation (1):

$$
M D A=\frac{\frac{2.71}{T_{s}}+3.29 \sqrt{\frac{R_{b}}{T_{b}}+\frac{R_{b}}{T_{s}}}}{\left(\text { efficiency) }\left(\frac{\text { probe area }}{100 \mathrm{~cm}^{2}}\right)\right.}
$$

where,

$\mathrm{R}_{\mathrm{b}}=$ Background counting rate (counts per minute) (cpm),

$\mathrm{T}_{\mathrm{b}}=$ Background count time ( $\left.\mathrm{min}\right)$, and

$\mathrm{T}_{\mathrm{s}}=$ Sample count time (min). 
TABLE 3 Final Survey Instrumentation

\begin{tabular}{|c|c|c|c|c|c|}
\hline $\begin{array}{c}\text { Type of } \\
\text { Measurement }\end{array}$ & Detector & Meter & Bkgd. & $\begin{array}{c}\text { Efficiency } \\
\left(4 \pi,{ }^{a} \%\right)\end{array}$ & Detection MDA \\
\hline Surface scans-alpha & $\begin{array}{l}425 \mathrm{~cm}^{2} \text { area gas prop, } \\
\text { Ludlum } 239-1 \mathrm{~F}\end{array}$ & $\begin{array}{l}\text { Countrate Meter, } \\
\text { Ludlum } 2221\end{array}$ & $4 \mathrm{cpm}$ & 16 & $570 \mathrm{dpm} / 100 \mathrm{~cm}^{2}$ \\
\hline Surface scans-alpha & $\begin{array}{l}75 \mathrm{~cm}^{2} \text { Scintillation, } \\
\text { Ludlum } 43-1\end{array}$ & $\begin{array}{l}\text { Countrate Meter, } \\
\text { Eberline ESP-1 }\end{array}$ & $2 \mathrm{cpm}$ & 25 & $500 \mathrm{dpm} / 100 \mathrm{~cm}^{2}$ \\
\hline Surface scans-aipha & $\begin{array}{l}100 \mathrm{~cm}^{2} \text { area gas prop, } \\
\text { Ludlum } 43-68\end{array}$ & $\begin{array}{l}\text { Countrate Meter, } \\
\text { Ludlum } 2221\end{array}$ & $5 \mathrm{cpm}$ & 24 & $380 \mathrm{dpm} / 100 \mathrm{~cm}^{2}$ \\
\hline Surface scans-beta & $\begin{array}{l}425 \mathrm{~cm}^{2} \text { area gas prop, } \\
\text { Ludlum } 239-1 \mathrm{~F}\end{array}$ & $\begin{array}{l}\text { Countrate Meter, } \\
\text { Ludlum } 2221\end{array}$ & $1300 \mathrm{cpm}$ & 21 & $4000 \mathrm{dpm} / 100 \mathrm{~cm}^{2}$ \\
\hline Surface scans-beta & $\begin{array}{l}100 \mathrm{~cm}^{2} \text { area gas prop, } \\
\text { Ludlum } 43-68\end{array}$ & $\begin{array}{l}\text { Countrate Meter, } \\
\text { Ludlum } 2221\end{array}$ & $140 \mathrm{cpm}$ & 16 & $2500 \mathrm{dpm} / 100 \mathrm{~cm}^{2}$ \\
\hline $\begin{array}{l}\text { Surface scans- } \\
\text { beta/gamma }\end{array}$ & $\begin{array}{l}15.5 \mathrm{~cm}^{2} \text { Pancake GM } \\
\text { Ludlum } 44-9\end{array}$ & $\begin{array}{l}\text { Countrate Meter, } \\
\text { Eberline ESP-1 }\end{array}$ & $50 \mathrm{cpm}$ & 12 & $\begin{array}{l}1300 \mathrm{dpm} / \mathrm{probe} \\
\text { area }\end{array}$ \\
\hline $\begin{array}{l}\text { Surface scans- } \\
\text { gamma }\end{array}$ & $\begin{array}{l}\text { NaI scintillation, } \\
\text { Ludlum } 44-10\end{array}$ & $\begin{array}{l}\text { Countrate Meter, } \\
\text { Ludlum } 2221\end{array}$ & $6800 \mathrm{cpm}$ & $\mathrm{N} / \mathrm{A}$ & $2 \mu \mathrm{R} / \mathrm{h}$ \\
\hline $\begin{array}{l}\text { Surface activity- } \\
\text { alpha }\end{array}$ & $\begin{array}{l}100 \mathrm{~cm}^{2} \text { gas prop, } \\
\text { Ludlum } 43-68 \\
\mathrm{t}_{\mathrm{s}}=3 \mathrm{~m}(\mathrm{~min})\end{array}$ & $\begin{array}{l}\text { Digital Scaler, } \\
\text { Ludlum } 2221\end{array}$ & $\begin{array}{l}5 \mathrm{cpm} \\
t_{b}=10 \mathrm{~m}\end{array}$ & 24 & $24 \mathrm{dpm} / 100 \mathrm{~cm}^{2}$ \\
\hline $\begin{array}{l}\text { Surface activity- } \\
\text { alpha }\end{array}$ & $\begin{array}{l}75 \mathrm{~cm}^{2} \text { scintillation } \\
\text { Ludlum } 43-1 t_{s}=3 \mathrm{~min}\end{array}$ & $\begin{array}{l}\text { Digital Scaler, } \\
\text { Eberline ESP-1 }\end{array}$ & $\begin{array}{l}3 \mathrm{cpm} \\
t_{b}=10 \mathrm{~m}\end{array}$ & 25 & $25 \mathrm{dpm} / 100 \mathrm{~cm}^{2}$ \\
\hline $\begin{array}{l}\text { Surface activity- } \\
\text { beta }\end{array}$ & $\begin{array}{l}100 \mathrm{~cm}^{2} \text { gas prop, } \\
\text { Ludlum } 43-68 \\
t_{\mathrm{s}}=0.2 \mathrm{~min}\end{array}$ & $\begin{array}{l}\text { Digital Scaler, } \\
\text { Ludlum } 2221\end{array}$ & $\begin{array}{l}140 \mathrm{cpm} \\
t_{b}=1 \mathrm{~m}\end{array}$ & 16 & $700 \mathrm{dpm} / 100 \mathrm{~cm}^{2}$ \\
\hline $\begin{array}{l}\text { Surface activity- } \\
\text { beta/gamma }\end{array}$ & $\begin{array}{l}\text { Pancake GM Ludlum } \\
44-9 t_{\mathrm{s}}=2 \mathrm{~min}\end{array}$ & $\begin{array}{l}\text { Digital Scaler, } \\
\text { Eberline ESP-1 }\end{array}$ & $\begin{array}{l}60 \mathrm{cpm} \\
t_{b}=5 \mathrm{~m}\end{array}$ & 12 & $1220 \mathrm{dpm} / 100 \mathrm{~cm}^{2}$ \\
\hline $\begin{array}{l}\text { Surface activity- } \\
\text { Tritium Wipes }\end{array}$ & $\begin{array}{l}\text { Liquid Scintillation } \\
\text { Beckman LS5000 TA }\end{array}$ & $\begin{array}{l}\text { Digital Scaler, }{ }^{c} \\
\text { Same as detector }\end{array}$ & $11 \mathrm{cpm}$ & 30 & $40 \mathrm{dpm} / 100 \mathrm{~cm}^{2}$ \\
\hline Exposure rates $^{\mathrm{d}}$ & $\begin{array}{l}\text { Pressurized ionization } \\
\text { chamber, RSS } 112\end{array}$ & (same as detector) & N/A & N/A & $<1 \mu \mathrm{R} / \mathrm{h}$ \\
\hline Gross $\alpha / \beta$ on smears & $\begin{array}{l}\text { Scintillation Ludlum } \\
2929 t_{\mathrm{s}}=4 \mathrm{~min}(\alpha), \\
t_{\mathrm{b}}=10 \mathrm{~min}(\beta)\end{array}$ & (same as detector ${ }^{\mathrm{c}}$ ) & $\begin{array}{l}0.3 \mathrm{cpm} \alpha \\
60 \mathrm{cpm} \beta\end{array}$ & $\begin{array}{l}39 \% \alpha \\
12 \% \beta\end{array}$ & $\begin{array}{l}5 \mathrm{dpm} \alpha \\
131 \mathrm{dpm} \beta\end{array}$ \\
\hline
\end{tabular}

a Nominal values.

b Monitoring audible signal.

c Integrated count time.

d Exposure rates will be determined using compensated $\mathrm{GM}$ or $\mathrm{NaI}$ detectors cross calibrated to a PIC. 
Sensitivities for scanning are calculated assuming a scanning speed of $1 / 3$ the detector width per second and by substituting the audibly discernable instrument response ( three times the background count rate) in Equation (2):

$$
M D A=\frac{3 * R_{b}}{(\text { efficiency })\left(\frac{\text { probe area }}{100 \mathrm{~cm}^{2}}\right)}
$$

MDAs for alpha scanning instrumentation listed in Table 3 have been calculated by ANL-E based on poisson background and sample count distributions at a $95 \%$ confidence level. Equation (1) was applicable when the counts accumulated during the scanning residence time allowed a gaussian approximation of a poisson distribution. The MDAs for direct and removable instruments were calculated in the same units as the fixed contamination results (i.e., $\mathrm{dpm} / 100 \mathrm{~cm}^{2}$ ).

For the smear counted, no correction for probe area was necessary to convert to units of $\mathrm{dpm} / 100 \mathrm{~cm}^{2}$ since the smeared surface area was approximately $100 \mathrm{~cm}^{2}$.

Instrument efficiencies are determined using a laboratory standard $\left(\mathrm{Tc}^{99}\right.$ and $\mathrm{Th}^{230}$ or $\left.\mathrm{H}^{3}\right)$ traceable to the National Institute Science and Technology. The combination of instrumentation and survey technique were chosen to provide a detection sensitivity of approximately $25 \%$ or less of the guideline release value for removable alpha, beta (including tritium), total alpha and total beta measurements.

\subsubsection{Daily Instrument Function Tests and Quality Assurance}

Sources and background were checked daily according to AR-HP-002, "Portable Instrument Procedure for Field Projects." Control charts and Chi-Square Tests were used to ensure that all instrumentation operated properly.

\subsection{SURVEY METHODOLOGY}

The survey methodology described herein is consistent with the procedures and recommendations included in NUREG/CR-5849, "Manual for Conducting Radiological Surveys in Support of License Termination." 


\subsubsection{Surface Scan}

Locations of residual surface and near surface activity were identified by scanning (frisking in the count rate mode at one-third detector width per second) surfaces according to the following schedule:

- Affected Area - $100 \%$ of surface.

- Upper surfaces above affected areas - scans in the immediate vicinity of each measurement.

- Unaffected area - $10 \%$ of floors/lower wall surfaces.

\subsubsection{Direct Measurements}

Alpha, and/or beta-gamma surface activity was checked by direct measurement (using the Ludlum Model 2221 in the scaler mode) according to the following schedule:

- Affected Areas - five measurements per grid for alpha and/or beta-gamma contamination.

- Upper Surfaces above Affected Areas - at a minimum, 30 biased measurement locations per quadrant or at least one location per $20 \mathrm{~m}^{2}$ of surface area, whichever was greater.

- Unaffected Areas - a minimum of 30 random measurements or an average measurement of one per $50 \mathrm{~m}^{2}$, whichever was greater.

\subsubsection{Removable Contamination Measurements}

One wipe $\left(100 \mathrm{~cm}^{2}\right)$ for removable contamination (alpha and/or beta-gamma) was taken in each grid of an affected area and at each measurement location in unaffected areas. All wipes were analyzed for both alpha and beta activity. Wipes for tritium analysis were taken in each grid suspected of having tritium contamination, i.e., in and around the fuel pool, the basement and basement sump, etc. 


\subsubsection{Exposure Rate Measurements}

Gamma exposure rate measurements were done at a distance of one $\mathrm{m}$ from surfaces. Measurements were uniformly spaced according to the following schedule:

- Gridded affected areas (floors and walls up to $2 \mathrm{~m}$ ) - one measurement per $4 \mathrm{~m}^{2}$.

- Unaffected Areas - one measurement at each randomly selected location on floors/lower wall surfaces.

\subsubsection{Special Measurements and Sampling}

Before final release survey activities, paint scrapings were obtained from the following areas and counted for alpha and beta activity:

- Lower walls of all four shell levels.

- Floors of all shell levels.

- Upper walls and ceilings of levels 3,2, and 1 .

- Upper walls of level 4.

These samples were obtained from locations where direct and removable contamination measurements did not indicate the presence of contamination. Paint samples were also collected from surfaces where direct and removable activity measurements made during the final survey suggested that contamination may have been painted over. After paint removal, the uncoated concrete or steel surface was scanned and surveyed for total and removable residual activity. Paint scrape sample counting results were evaluated to determine whether alpha or beta contamination remained in the paint or other coating medium. 


\subsection{INTERPRETATION OF SURVEY RESULTS}

Direct contamination readings were converted to $\mathrm{dpm} / 100 \mathrm{~cm}^{2}$ using the Equation (3):

$$
d p m / 100 \mathrm{~cm}^{2}=\frac{\text { gross cpm }- \text { background cpm }}{(\text { efficiency })\left(\frac{\text { probe area }}{100 \mathrm{~cm}^{2}}\right)}
$$

The average background count rate for the direct survey instrumentation was determined and each direct measurement of fixed contamination was 1 minute in duration. If a direct measurement resulted in a value less than the calculated MDA for the survey instrumentation, this was recorded as the value for the MDA (i.e., if the MDA for beta-gamma activity was 874 , a value measured below MDA was recorded as 874). To ensure that the average contamination levels satisfied the guideline values, the results were evaluated to determine whether the data for each survey unit provides a $95 \%$ confidence level that the true mean activity level met the guidelines. The following equation was used for testing the data within each survey unit, relative to the guideline value, at the $95 \%$ confidence level:

$$
\mu_{\alpha}=x_{a v e}+t_{1-\alpha, d f} \frac{s_{x}}{\sqrt{n}}
$$

where:

$$
\begin{aligned}
\mathrm{x}_{\mathrm{ave}} & =\text { calculated mean for a survey unit, } \\
\mathrm{t}_{1-\alpha, \mathrm{df}}= & 95 \% \text { confidence level for } \mathrm{n}-1 \text { degrees of freedom, } \\
\mathrm{s}_{\mathrm{x}}= & \text { standard deviation of measurements in a survey unit, and } \\
\mathrm{n}= & \text { number of measurements within a survey unit used to determine } \mathrm{x}_{\mathrm{ave}} \\
& \text { and } \mathrm{s}_{\mathrm{x}} .
\end{aligned}
$$

The value of $\mu_{\alpha}$ was compared with the guideline value. All values of $\mu_{\alpha}$ were less than the guideline. Therefore, each survey unit met the guideline at the $95 \%$ confidence level and no further survey action was necessary. 


\subsection{FINAL SURVEY RESULTS}

ALARON began the final survey of the EBWR facility in December 1995 and completed the survey in November 1995. During this survey the facility operated under restrictions necessary to maintain the shell as a "Potentially Contaminated Area."

\subsection{ANL-E VERIFICATION SURVEY}

ANL-E HP performed the verification survey immediately after the ALARON completed the final survey for a clearly defined area, including portions of a wall, ceiling, or floor. ANL-E HP used the same grid and reference system use by ALARON. The EBWR facility, except inaccessible areas (Section 5.5), met the release criteria.

\subsection{POST-DECOMMISSIONING HAZARDOUS MATERIAL CONDITION}

At the conclusion of the verification survey, all hazardous material had been removed to below release limits except in inaccessible areas. Hazardous and mixed waste were not present in the facility at the time of the verification survey. Residual radioactive material remaining in the accessible areas of the facility is below the activity levels listed in Section 6.2.1 for unrestricted release. 


\section{COST AND SCHEDULE}

\subsection{EBWR D\&D PROJECT SCHEDULE}

The EBWR D\&D project began in April 1986 and was completed in February 1996, lasting a total of 118 months with approximately four months of project down time. Figure 40 shows a schedule of the project from initiation to the completion of the final report. Phase I began in April 1986 and finished with the removal of all asbestos in the facility in March 1988. Phase II began in April 1988 and ended in September 1989. At the end of the EBWR Systems D\&D (Phase II), a 50 -month preparatory period was initiated. During this period, activities pertaining to the removal of radioactive material were performed, including installing a facility wide HEPA system and ensuring all needed equipment was procured. The Phase III preparatory period began in October 1989 and ended in November 1993.

D\&D of the reactor vessel and internals was completed by ALARON during Phase III (including Phases IIIA and IIIB). Phase IIIA and IIIB tasks were performed simultaneously. Activities began in December 1993 and ended November 1995. Phase IV began with the removal of the bioshield. Initial bioshield removal began in May 1994 and ended in December 1994. During this time the project was shut down due to the unexpected uptake of Am ${ }^{241}$ by several D\&D workers, between September 1994 and November 1994. Once the initial bioshield removal was completed, the project again shut down pending the final review by the investigation team. Work resumed in the pool on Phase III and additional Phase IV activities, including the removal of decontamination systems, from February 1995 to November 1995. Bioshield removal resumed from August 1995 to November 1995, when all remaining radioactivity was rendered inaccessible. Phase IV activities included the final survey. Phase III activities lasted 19 months total. Phase IV lasted 13 months total, including shutdown. Project closeout activities, the ANL confirmation survey and the issuance of the final report occurred from May 1995 to February 1996.

\subsection{EBWR D\&D PROJECT COST}

The estimated total cost of the project was $\$ 19,586,000$.

\subsection{EBWR D\&D PROJECT EXPOSURE SUMMARY}

Figure 41 represents the total exposure to all personnel over the duration of the project. Total exposure is separated into the project phases and project closeout. 


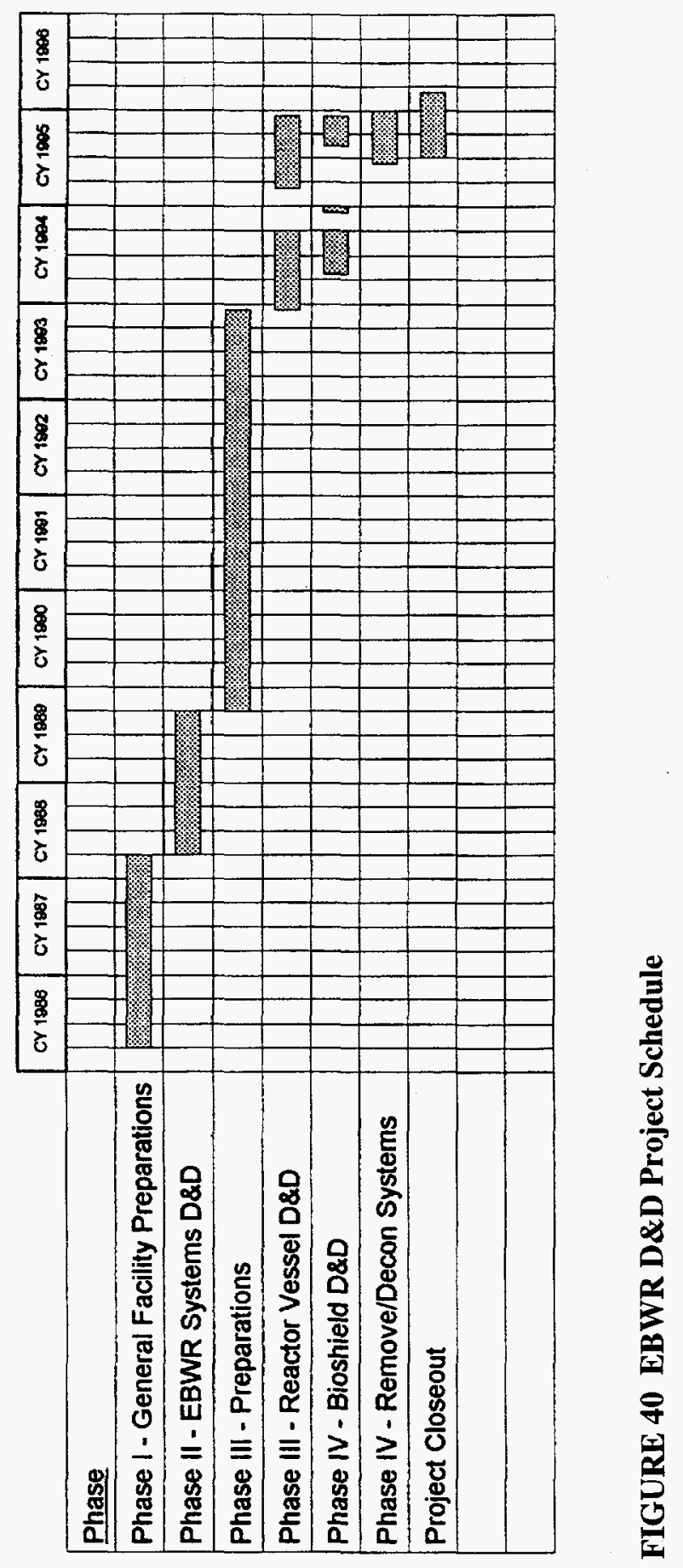




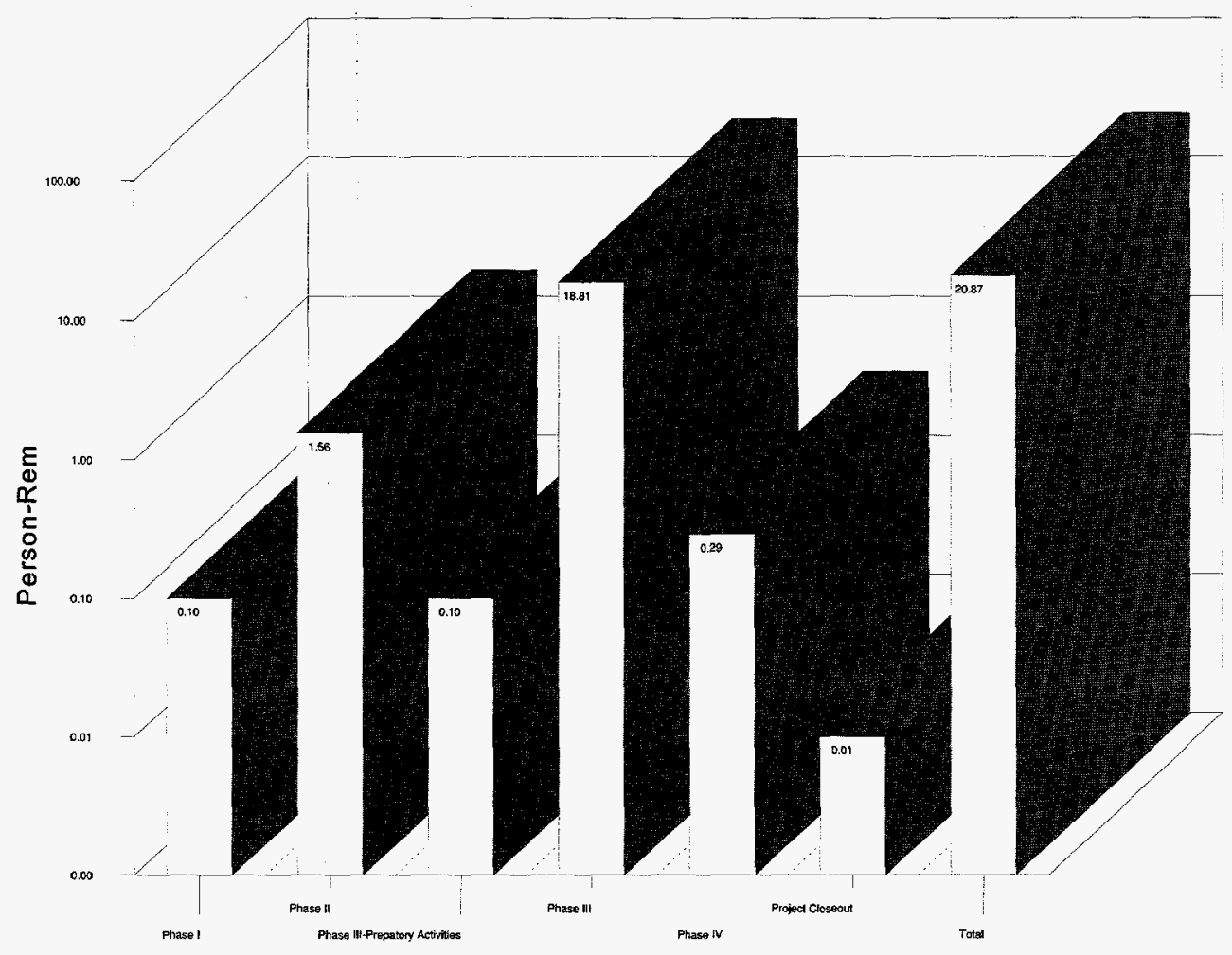

FIGURE 41 Exposure Breakdown for EBWR D\&D Project

The greatest exposure occurred while removing the reactor vessel and reactor internals (Phases IIIA and IIIB). These portions represented $188.1 \mathrm{mSv}$ (18.81 rem) of the total 208.7 person$\mathrm{mSv}$ (20.87 person-rem) of exposure to project personnel. The remaining phases amounted to 20.6 person-mSv (2.06 person-rem) combined. The EBWR Project administrative dose limit to radiation workers is $15 \mathrm{mSv}$ (1.5 rem) per year. No project personnel reached this limit. See Section 9.0 for personnel exposure results. 


\section{WASTE VOLUME}

\subsection{WASTE TYPES}

The D\&D of the EBWR was begun in 1986 with waste generation occurring during 1986 through 1995. The twenty plus years of radioactive decay resulted in $\mathrm{Co}^{60}$ being the predominant radionuclide. During this period any waste materials having detectable counts above background were disposed of as radioactive waste. Radioactive waste was sent initially to the RWMC at Idaho National Engineering Laboratory (INEL). Waste was later sent to the low level waste repository on the DOE Hanford site, WA.

Waste from Phase I, Phase II, and a portion of Phase III was packaged and manifested between February 1986 and January 1991 (waste shipped before May 1986 was previously stored on site). At that time D\&D waste generation was suspended while miscellaneous surveillance and maintenance activities were performed, including installing a facility-wide HEPA system and refurbishing the building for the remaining D\&D activities. D\&D waste packaging resumed in May 1994 and continued to the end of the project.

All waste materials generated during this project were classified as either low level radioactive waste, mixed waste, of clean/free release according to the criteria contained in "DOE Guidelines for Residual Radioactivity at Formerly Utilized Sites Remedial Action Program and Remote Surplus Facilities Management Program Sites." Materials classified as clean were salvaged for reuse, disposed of as scrap, or placed in the ANL-E on-site landfill or in an off-site landfill. Radioactively contaminated waste was further classified according to its composition and the level of its radioactivity. Liquid radioactive waste was converted to a solid form using existing ANL-E waste processing facilities.

\subsection{WASTE VOLUME}

The EBWR D\&D project generated low level radioactive waste, mixed waste, and clean waste. These wastes consisted of both liquid and solid wastes. All liquid waste was transferred directly to WMO in approved containers or pipelines.

Clean waste was free released and recycled or disposed of off-site in a sanitary facility. A total of approximately $102,725 \mathrm{~kg}(226,000 \mathrm{lb})$ of steel and $15,909 \mathrm{~kg}(35,000 \mathrm{lb})$ of concrete were scrapped or recycled as clean material. Mixed waste was transferred to WMO and stored on-site. Some material was shipped to the DOE Hanford Site. Liquid radioactive waste was treated on-site. Low level radioactive waste was packaged at the EBWR facility and shipped to the low level waste disposal site at the DOE INEL facility near Idaho Falls, ID (Phases I and II) or the DOE Hanford site 
near Hanford, WA (Phases III and IV). A description of the waste generated during the EBWR D\&D project is outlined in Section 7.2.1.

\subsubsection{Radiological Waste}

The EBWR D\&D project generated approximately $420.4 \mathrm{~m}^{3}\left(14,841 \mathrm{ft}^{3}\right)$ of low-level radioactive waste requiring off-site disposal. The waste included materials and equipment that could not be decontaminated, including the reactor vessel and its internals, process and drain systems piping, ion exchangers, pumps, tanks, filters, and contaminated building materials comprised primarily of concrete. Neither high level nor TRU wastes were generated during this project. The approximate amount of radioactive material generated during this project is as follows:

\begin{tabular}{lrrll}
\hline \multicolumn{1}{c}{ Type } & \multicolumn{2}{c}{ Volume $\mathrm{m}^{3}\left(\mathrm{ft}^{3}\right)$} & \multicolumn{2}{c}{ Weight $\mathrm{kg}(\mathrm{lb})$} \\
\hline & & & & \\
Metal & 200.0 & $(7,601)$ & 167,712 & $(368,966)$ \\
Concrete & 63.8 & $(2,252)$ & 85,705 & $(188,550)$ \\
Compactibles \& & & & & \\
$\quad$ Miscellaneous & 156.6 & $(5,528)$ & 106,789 & $(234,936)$ \\
Total & 420.4 & $(14,841)$ & 360,206 & $(792,452)$ \\
\hline
\end{tabular}

Waste material generated during Phases I, II and some Phase III was packaged and shipped between 1986 and 1991. Generally, M3A half bins were used for concrete and thick walled components while M3A full bins were used for metal and other materials. Often, materials were placed in wooden liners before final packaging in the M3A bins. Table 4 provides a summary of the radiological waste packaged between 1986 and 1991:

D\&D operations and waste packaging from Phases IIIA, IIIB, and IV resumed beginning in 1994. During 1994-1996, 134 packages including M3A 1/2 Bins, E-48, 55 gallon drums, E-96, and 7-100 containers were filled with low level radioactive waste, sealed, and transported off-site or placed into on-site storage. Materials with the greatest activity were placed into liners and loaded into 208 liter (55 gallon) drums. These drums were classified as remote-handled low level radioactive waste. All other bins were classified as contact handled low level radioactive waste.

The weight of the individual containers ranged from 45.5 to $4,318 \mathrm{~kg}$ (100 to $9,500 \mathrm{lb}$ ), with a total weight of $215,024 \mathrm{~kg}(473,052 \mathrm{lb})$ and a total volume of $229.7 \mathrm{~m}^{3}\left(8,109 \mathrm{ft}^{3}\right)$. The total activity of the individual packages ranged from 0.0518 to $9,052,738 \mathrm{MBq}(0.0014$ to $244,668.6 \mathrm{mCi})$, with a total activity of $24,782,508 \mathrm{MBq}(669,797.5 \mathrm{mCi})$. The dose rate from the individual packages ranged from $<0.1$ to $11,500 \mathrm{mR} / \mathrm{hr}$ at 1 meter. Table 5 gives a summary of the 
TABLE 4 EBWR D\&D Project Radioactive Waste Shipments from 1986 to 1991

\begin{tabular}{|c|c|c|c|c|c|c|c|c|c|}
\hline \multirow[b]{2}{*}{ Contents } & \multirow{2}{*}{$\begin{array}{c}\text { Package } \\
\text { Type }\end{array}$} & \multirow{2}{*}{$\begin{array}{c}\text { No. of } \\
\text { Packages }\end{array}$} & \multicolumn{2}{|c|}{ Volume $^{\mathbf{a}}$} & \multicolumn{2}{|c|}{ Weight $^{\mathbf{a}}$} & \multicolumn{2}{|c|}{ Activity } & \multirow{2}{*}{$\begin{array}{c}\text { Max Dose } \\
\text { Rate } \\
(\mathrm{mR} / \mathrm{hr})\end{array}$} \\
\hline & & & $\mathrm{ft}^{3}$ & $\mathrm{~m}^{3}$ & $\mathrm{lb}$ & kg & $\mathrm{mCi}$ & $\mathrm{MBq}$ & \\
\hline \multirow[t]{2}{*}{ Metal } & M3A Bin & 36 & 4,896 & 138.7 & 213,800 & 97,182 & 369.3 & 13,664 & 30 \\
\hline & $\mathrm{M} 3 \mathrm{~A} 1 / 2 \mathrm{Bin}$ & 1 & 68 & 1.9 & 4,400 & 2,000 & 1.5 & 56 & 6 \\
\hline \multirow[t]{2}{*}{ Concrete } & M3A Bin & 4 & 544 & 15.4 & 28,200 & 12,818 & 0.5 & 19 & 1 \\
\hline & $\mathrm{M} 3 \mathrm{~A} 1 / 2 \mathrm{Bin}$ & 10 & 680 & 19.3 & 64,800 & 29,455 & 52.7 & 1,950 & 10 \\
\hline Compactibles & M3A Bin & 4 & 544 & 15.4 & 8,200 & 3,727 & 4.15 & 154 & 10 \\
\hline Total & & 55 & 6,732 & 190.7 & 319,400 & 145,182 & 428.2 & 1,5843 & \\
\hline
\end{tabular}

a Including liners.

TABLE 5 Summary of Highest Radiological Levels Associated with Packaged Low Level Waste During 1994-1996

\begin{tabular}{|c|c|c|c|c|c|c|c|c|c|}
\hline \multirow[b]{2}{*}{ Contents } & \multirow{2}{*}{$\begin{array}{c}\text { Package } \\
\text { Type }\end{array}$} & \multirow{2}{*}{$\begin{array}{c}\text { No. of } \\
\text { Packages }\end{array}$} & \multicolumn{2}{|c|}{ Volume } & \multicolumn{2}{|c|}{ Weight $^{c}$} & \multicolumn{2}{|c|}{ Activity } & \multirow{2}{*}{$\begin{array}{c}\text { Max Dose } \\
\text { Rate } \\
\text { (mR/hr) }\end{array}$} \\
\hline & & & $\mathrm{ft}^{3}$ & $\mathrm{~m}^{3}$ & $\mathrm{lb}$ & $\mathrm{kg}$ & $\mathrm{mCi}$ & $\mathrm{MBq}$ & \\
\hline \multirow[t]{5}{*}{ Metal } & $\mathrm{M} 3 \mathrm{~A} 1 / 2 \mathrm{Bin}$ & 13 & 884 & 25.3 & 39,650 & 18,023 & 1,205 & 44,585 & 15 \\
\hline & E-96 & 2 & 192 & 5.5 & 14,250 & 6,477 & 128 & 4,736 & 6 \\
\hline & E-48 & 14 & 672 & 19.2 & 77,000 & 35,000 & 845 & 31,265 & 10 \\
\hline & 55 Gal Drum & 22 & 165 & 4.7 & 11,630 & 5,286 & 601,461 & $22,254,057$ & 11,500 \\
\hline & $7-100$ & 2 & 184 & 5.3 & 8,236 & 3,744 & 64,083 & $2,371,071$ & 2,480 \\
\hline \multirow[t]{2}{*}{ Concrete } & $\mathrm{M} 3 \mathrm{~A} 1 / 2 \mathrm{Bin}$ & 1 & 68 & 1.9 & 5,750 & 2,614 & 4.26 & 158 & 0.2 \\
\hline & E-96 & 10 & 960 & 27.4 & 89,800 & 40,818 & 77 & 2,849 & 1.4 \\
\hline \multirow{2}{*}{$\begin{array}{l}\text { Multiple } \\
\text { Media }^{\mathrm{a}}\end{array}$} & $\mathrm{M} 3 \mathrm{~A} 1 / 2 \mathrm{Bin}$ & 6 & 408 & 11.7 & 12,350 & 5,614 & 415 & 15,355 & 10 \\
\hline & E-96 & 8 & 768 & 21.9 & 31,600 & 14,364 & 478 & 17,686 & 7 \\
\hline Miscell. ${ }^{\mathrm{b}}$ & $\mathrm{M} 3 \mathrm{~A} 1 / 2 \mathrm{Bin}$ & 56 & 3,808 & 108.8 & 182,786 & 83,085 & 1101.68 & 40,762 & 12 \\
\hline TOTAL & & 134 & 8,109 & 231.7 & 473,052 & 215,025 & 669,798 & $24,782,489$ & \\
\hline
\end{tabular}

a Multiple Media contains metal, concrete, and compactible materials in approx. equal amounts.

b Miscellaneous contains primarily concrete and metal punchings, with some compactibles.

c Includes weight of liners. 
Low Level Waste shipments made between 1994 and 1996. Included in this table are the containers with the greatest levels of radioactivity in millicuries, and the containers with the greatest dose rates at 1 meter. A complete history of low level radioactive shipments for this project during 1986-1996 is included in Appendix A.

The wastes summarized in Table 5 were produced primarily in Phases IIIA, IIIB and IV. Twenty-six bins were shipped to the INEL RWMC facility near Idaho Falls, ID between 1986-1991. When INEL closed the waste disposal site to non-Idaho source waste, the remaining 29 bins from 1986-1991 and all 134 packages from 1994-1996 were shipped to the DOE-Hanford waste disposal site near Richland, WA.

\subsubsection{Special Waste}

There were three hazardous material waste streams generated during the D\&D of the EBWR. These including asbestos, activated lead and contaminated lead.

Approximately $72.9 \mathrm{~m}^{3}\left(2,574 \mathrm{ft}^{3}\right)$ of asbestos was removed from the facility. Approximately $71.9 \mathrm{~m}^{3}\left(2,538 \mathrm{ft}^{3}\right)$ of non-radiologically contaminated asbestos was disposed of on-site at the ANL-E landfill. Approximately $1 \mathrm{~m}^{3}$ (36 $\mathrm{ft}^{3}$ of asbestos) weighing $292 \mathrm{~kg}(642 \mathrm{lb})$ containing low level radioactivity was shipped to the INEL disposal site as low level radioactive waste.

Additionally, $68,182 \mathrm{~kg}(150,000 \mathrm{lb})$ of bioshield lead was removed from the EBWR. Survey efforts resulted in release for recycling of $61,137 \mathrm{~kg}(134,500 \mathrm{lb})$. The remaining $7,045 \mathrm{~kg}$ $(15,500 \mathrm{lb})$ of potentially activated lead was disposed of as mixed waste in fifty-five 208.2 liter (55 gallon) drums with a total volume of $11.7 \mathrm{~m}^{3}\left(413 \mathrm{ft}^{3}\right)$. These drums ranged in weight from 181.8 to $397.7 \mathrm{~kg}$ (400-875 lb), with a total weight of $17,491 \mathrm{~kg}(38,480 \mathrm{lb})$, including liners. The activity of the individual drums ranged from 2.81 to $79.6 \mathrm{MBq}(0.076-2.07 \mathrm{mCi})$, with a total activity of $1,736 \mathrm{MBq}(46.93 \mathrm{mCi})$. The dose rates emitted from the packages ranged from 0.02 to $0.2 \mathrm{mR} / \mathrm{hr}$.

Two 208.2 liter (55 gal) drums and two M3A 1/2 Bins were packaged with $4.3 \mathrm{~m}^{3}\left(151 \mathrm{ft}^{3}\right)$ of contaminated lead from ion exchangers and recycle filters. The 208.2 liter drums and M3A $1 / 2$ Bins weighed had a total weight of $9,046 \mathrm{~kg}(19,901 \mathrm{lb})$, including liners. The activity of the drums each had $71.7 \mathrm{MBq}(1.937 \mathrm{mCi}$ ), while the two M3A $1 / 2 \mathrm{Bins}$ had activities of 395.9 and $895.4 \mathrm{MBq}(10.7$ and $24.2 \mathrm{mCi})$, with a total activity of $1,435 \mathrm{MBq}(38.8 \mathrm{mCi})$. The dose rates emitted from the packages ranged from 0.02 to $0.8 \mathrm{mR} / \mathrm{hr}$. A complete summary of mixed waste packages is included with the summary of low level radioactive waste packages in Appendix A. 
The paint on the EBWR retention tanks was found to contain lead and PCBs. Additionally, PCBs were found in some electrical equipment. The paint was removed and disposed of as hazardous waste.

\subsubsection{Clean Waste}

Waste not classified as low level radioactive waste or mixed waste was released as clean waste. This waste was either recycled, reused, or disposed of at a sanitary landfill.

\subsection{WASTE PACKAGING}

Packaging of radioactive waste generated by the EBWR D\&D project conformed with Department of Transportation (DOT) regulations and with the requirements of the receiving waste disposal site. Standard M3A half size bins, E-48, 55 gallon drums, E-96, and 7-100 cask liners were filled with low level radioactive waste, sealed, and transported off-site or placed into on-site storage. The M3A bins are made of 12 gauge steel reinforced with angle iron and measure $1.22 \mathrm{~m}$ by $1.52 \mathrm{~m}$ by $1.83 \mathrm{~m}$ height ( $4 \mathrm{ft}$ by $5 \mathrm{ft}$ by $6 \mathrm{ft}$ ) in height. A cover made of the same material and equipped with an integral gasket is fastened to the bin with eight bolts. The bin has a load limit of $3636.4 \mathrm{~kg}$ $(8,000 \mathrm{lb})$ and meets DOT requirements for the shipment of LSA waste.

Radioactive waste requiring remote handling was size reduced as necessary and packaged in 208 liter (55 gallon) steel drums or cask liners. When required, shipments were placed in DOT approved shielded containers. E-96 bins were used for items that could not be size reduced and/or were too large or too heavy to be contained in standard packaging.

Liquid radioactive waste generated during decontamination operations was processed into a solid by evaporation or other means after neutralization and then placed into standard packaging for off-site shipment. Liquid volumes were approximately 151,416 liters (40,000 gal) over the term of the project. The radioactive liquids generated during the EBWR D\&D project resulted from D\&D operations and were not associated with the original facility operations.

\subsection{WASTE TRANSPORT}

Packaged radioactive waste from the project was transported to the DOE radioactive waste disposal sites by "Exclusive Use" tractor-trailer trucks. EBWR waste was sometimes combined with other low-level radioactive waste generated from other ANL-E operations and sent to the DOE sites for disposal. Special transport vehicles were used to ship radioactive items that could not be 
transported routinely due to size, weight, radioactivity, or a combination of characteristics. All radioactive waste shipments met DOT and DOE regulations for transporting such materials.

Substantial quantities of materials and equipment were salvaged during the EBWR D\&D project. Efforts were made not only to separate radioactively contaminated items from clean items, but to identify radioactively contaminated items that could be decontaminated economically. The ultimate disposition of items was decided on a case-by-case basis and, when feasible, radioactively contaminated items were decontaminated to unrestricted use levels. Uncontaminated and decontaminated items were reused, released for scrap or placed in a sanitary landfill. 


\section{OCCUPATIONAL EXPOSURE TO PERSONNEL}

ALARA principles were applied to all D\&D activities involving exposure to radioactive materials. Only personnel who were essential to $D \& D$ activities were exposed to radioactivity during D\&D operations. A project ALARA Committee was formed to review procedures and make recommendations to management where necessary for improving progress toward minimizing radiation exposure and radiological releases. The Committee evaluated items such as construction and design of the containment tent and decontamination/dismantling activities, and tested plans for exposure and waste minimization. The ALARA Committee met the requirements specified in Article 138 of the site-specific ANL-E Radiological Control Manual.

Engineering controls, including the construction of plastic sheeting covered workenclosures with HEPA filtered air exhausts under negative pressure, were implemented where applicable. Protective clothing including NIOSH approved respirators and breathing apparatus were worn whenever workers were potentially exposed to airborne radioactivity. Tools and devices were remotely operated whenever possible. Mock up equipment was developed to assist worker training in high exposure areas. Special lead shields and baskets were developed to shield personnel from radioactive exposure. Personnel barriers around work zones were established, with radiation monitoring stations at points of egress. Work personnel ensured the open ends of pipes, tubes, and other components were sealed immediately upon disassembly. Finally, computer generated images and training films were used to assist personnel in training and understanding various activities involving radioactive materials.

All radiological work was performed using a RWP. The RWP is an administrative mechanism used to establish radiological control for intended work activities. The RWP informed workers of area radiological conditions and entry requirements, including pre-job briefing, training, and protective clothing. Postings were used to alert personnel to the presence of radiation and radioactive materials. Signs followed established color schemes and verbiage, and in areas of ongoing work activities, the dose rate and contamination level or range of each area was included on or with each posting as applicable. Area controls, such as rope and tape, indicated the boundaries of the work area and followed established color schemes and criteria. To prevent the spread of radioactive contaminants off-site, all personnel, vehicles, tools, and other equipment were surveyed for radiation whenever they left the work area.

\subsection{TOTAL DOSE}

Over the project's 118 month duration, personnel received a total dose equivalent of 208.7 person-mSv (20.87 person-rem). Most of the dose equivalent was incurred in project Phase III during a 8 month period, during the disassembly of the reactor vessel complex. A total dose of 
188.1 person-mSv (18.81 person-rem) was incurred to project personnel during this phase. The use of mockups and training sessions (including computer simulation) and shields significantly reduced the overall person-rem from the estimated dose. Phase II of the project, which accomplished the disassembly of all EBWR process and auxiliary systems, incurred a dose equivalent of 15.6 person-mSv ( 1.56 person-rem) over a period of 18 months. The dose equivalents incurred during project Phases I, II, and project closeout were small. Exposure dose equivalents to project personnel were estimated in the EBWR project plan issued in 1989. Table 6 provides a summary of the actual dose equivalent incurred during this project compared with the 1989 estimated dose equivalent.

The original estimated dose to EBWR D\&D project personnel was more than 400 person-mSv ( 40 person-rem) over the lifetime of the project. Engineering controls, including the manufacture of mockup and extra shielding, and the use of computer simulated D\&D team training films decreased the total person-rem project exposure by approximately $48 \%$.

\subsection{AMERICIUM UPTAKE}

On September 2, 1994, ANL-E Dosimetry and Analytical (DA) Services notified the Area Health Physicist that two individuals had positive indications that an uptake of tritium and a 5.5 alpha emitter had occurred since their baseline urine sample had been collected. Uptakes of transuranics were not expected. The EBWR Project Manager was notified on 5 September 1994, and meetings were held discussing possible sources of tritium and transuranics. None were identified based on known history and plant systems. Work activities continued pending confirmation of

TABLE 6 Estimated Total Radiation Dose Equivalent Incurred during the EBWR D\&D Project

\begin{tabular}{clccc}
\hline $\begin{array}{c}\text { Project } \\
\text { Phase }\end{array}$ & \multicolumn{1}{c}{ Description } & $\begin{array}{c}\text { Duration } \\
\text { (Months) }\end{array}$ & $\begin{array}{c}\text { Estimated Dose } \\
\text { Equivalent } \\
\text { (Person-Rem) }\end{array}$ & $\begin{array}{c}\text { Actual Dose } \\
\text { Equivalent } \\
\text { (Person-Rem) }\end{array}$ \\
\hline I & Preparatory Activities & 24 & 0.10 & 0.10 \\
II & EBWR Systems Disassembly & 18 & 12.80 & 1.56 \\
& Preparatory Activities & 50 & - & 0.10 \\
III & Reactor Vessel Complex Disassembly & 19 & 26.80 & 18.81 \\
IV & Biological Shield & 13 & 0.30 & 0.29 \\
& Project Closeout & 8 & - & 0.01 \\
& Total & 132 & 40.00 & 20.87 \\
\hline
\end{tabular}


bioassay results. On September 9, 1994, analysis of a fecal sample from one of the contract personnel confirmed the presence of Americium $241\left(\mathrm{Am}^{241}\right)$. D\&D work inside the EBWR Shell was immediately halted. Investigative work and HP survey efforts went on to determine the cause/source of the $\mathrm{Am}^{241}$. Required surveillance and critical maintenance, such as changing filters in air and water systems were enacted to maintain a safe work environment and protect operating equipment. Additional bioassay samples were taken to determine the number of people affected.

Analysis of fuel pool water and fuel pool water filtration system filters indicate the presence of fission products $\left(\mathrm{Cs}^{137}, \mathrm{Sr}^{90}\right)$ and transuranics $\left(\mathrm{Am}^{241}\right)$. Analysis of air samples taken on July 19 , 1994 near the fuel pool during control rod cutting operations indicated the presence of fission products $\left(\mathrm{Cs}^{137}\right)$ and transuranics $\left(\mathrm{Am}^{241}, \mathrm{Pu}^{238}\right.$ and $\mathrm{Pu}^{239}$ ). Previous characterizations had not reported these nuclides. Discussions with personnel previously involved with EBWR operations raised a concern regarding the possibility of the control rods having fueled followers (the non-poison section of the rod containing fuel). Based on the above information WMO halted all waste shipments of the remote handled drums of irradiated hardware segmented in the pool until analytical testing was completed to verify the waste characterization. Shipments of contact handled $(<200 \mathrm{mR} / \mathrm{hr})$ waste bins were also stopped.

Baseline bioassay measurements were established for each contractor employee. $\mathrm{Am}^{241}$ was not detected in the baselines. A total of (7) seven contractor personnel had positive results for $\mathrm{Am}^{241}$, and detectable other nuclides such as $\mathrm{H}^{3}, \mathrm{Co}^{60}, \mathrm{Cs}^{137}$ and $\mathrm{Sr}^{90}$ in urine sample analysis (see Table 7 below). Urine analysis for all other project personnel (contractor and ANL-E) indicated no detectable $\mathrm{Am}^{241}$.

TABLE 7 Analytical Results for Urine Samples (All Results in dpm/Liter)

\begin{tabular}{cccccc}
\hline Worker & $\mathrm{Am}^{241}$ & $\mathrm{Co}^{60}$ & $\mathrm{Cs}^{137}$ & $\mathrm{Sr}^{90}$ & $\mathrm{H}^{3}$ \\
\hline 1 & $0.133 \pm 0.024$ & 1,474 & 134 & 61 & 32,270 \\
2 & $0.085 \pm 0.016$ & 1,120 & $\mathrm{ND}$ & 85 & 24,930 \\
3 & $0.030 \pm 0.011$ & 278 & $\mathrm{ND}$ & 20 & 11,860 \\
4 & $0.029 \pm 0.008$ & 456 & $\mathrm{ND}$ & $\mathrm{ND}$ & 18,370 \\
5 & $0.017 \pm 0.006$ & 486 & 65 & $\mathrm{ND}$ & 17,450 \\
6 & $0.016 \pm 0.006$ & 167 & $\mathrm{ND}$ & $\mathrm{ND}$ & 17,620 \\
7 & $0.010 \pm 0.005$ & 233 & $\mathrm{ND}$ & $\mathrm{ND}$ & 6,550 \\
\hline
\end{tabular}

Note $: \mathrm{ND}=$ not detectable. 
The use of bioassays, daily air samples, and administrative controls (including RWP signins) resulted in an accurate reconstruction of events. Six of the seven affected workers were involved with plasma arc operations in or above the fuel pool. The uptake occurred over a four day period, with the greatest uptake in individual working longest with cutting operations. Speculation remains as to the source of the americium. It may have been a product of a $\mathrm{Pu}^{241}$ foil lost in the EBWR facility during experiments run in 1967. The $\mathrm{Pu}^{241}$ would have decayed into $\mathrm{Am}^{241}$; however, no trace of $\mathrm{Pu}^{241}$ was found. Another scenario is that although no fuel element failure was reported, undetectable microscopic cracks may have allowed the release of transuranics over the lifetime of EBWR. Two of the contract personnel received approximately 3 micro Sievert (mSv) [300 millirem (mrem)] from the uptake of $\mathrm{Am}^{241}$. The remaining personnel are estimated to have received between 500 and $600 \mu \mathrm{Sv}$ (between 50 and $60 \mathrm{mrem}$ ) from the uptake of $\mathrm{Am}^{241}$.

The ANL-E Administrative Limit is $10 \mathrm{mSv} /$ year $(1.0 \mathrm{rem} / \mathrm{year})$. The EBWR Project Administrative Limit is $15 \mathrm{mSv}$ (1.5 rem) per year. The DOE Administrative Limit is $20 \mathrm{mSv}$ (2.0 rem) per year. The DOE Legal Limit is $50 \mathrm{mSv}$ ( $5 \mathrm{rem})$ per year.

Based on HP and other investigative work, work packages detailing the remaining activities were developed. D\&D activities in the bioshield were allowed to continue from November 1994 to December 1994, and waste shipments resumed. Work activities again stopped when bioshield activities were complete in December 1995, pending approval by the investigation team to begin work in the fuel pool. These activities resumed in February 1995. 


\section{FINAL FACILITY CONDITION}

The radioactive release criteria established for the EBWR D\&D Project are based on the requirements outlined in DOE Order 5400.5, "Radiation Protection of the Public and the Environment" and ANL-E Health Physics Procedures. These limits are as follows:

For beta-gamma emitters (e.g., $\left.\mathrm{Cs}^{137}\right)$ :

$83 \mathrm{~Bq}(5000 \mathrm{dpm}) / 100 \mathrm{~cm}^{2}$, average (over $1 \mathrm{~m}^{2}$ ) fixed plus removable contamination, $17 \mathrm{~Bq}(1000 \mathrm{dpm}) / 100 \mathrm{~cm}^{2}$, removable contamination, and $250 \mathrm{~Bq}(15,000 \mathrm{dpm}) / 100 \mathrm{~cm}^{2}$, maximum fixed plus removable contamination.

For transuranic contamination (e.g., $\mathrm{Am}^{241}$ ):

$1.67 \mathrm{~Bq}(100 \mathrm{dpm}) / 100 \mathrm{~cm}^{2}$, average (over $1 \mathrm{~m}^{2}$ ) fixed plus removable contamination, $0.3 \mathrm{~Bq}(20 \mathrm{dpm}) 100 \mathrm{~cm}^{2}$, removable contamination, and

$5 \mathrm{~Bq}(300 \mathrm{dpm}) / 100 \mathrm{~cm}^{2}$, maximum fixed plus removable contamination.

All accessible surface areas within the EBWR facility were decontaminated to below these levels (refer to Appendices B and C for final survey results). Additionally, exposure rates in occupied location were measured at no more than $5 \mu \mathrm{R} / \mathrm{h}$ above background, while exposure rates at 1 meter from surface locations do not exceed $10 \mu \mathrm{R} / \mathrm{hr}$ above background. All areas in the EBWR facility containing residual radioactivity above these release criteria were made inaccessible by means of capping (either wood, metal, concrete, or a combination of these). Based on these results and lack of additional hazardous materials at the site, the EBWR facility has been released as a Radiologically Controlled Area. Currently, standard training is required to enter the facility unescorted; however, RWPs, exposure monitoring and additional controls are not in effect.

All reactor systems and associated equipment have been removed from the facility. Exposed concrete has been removed to the point where residual activity is below guidelines. Electrical, water, and compressed air systems are fully or partially operational. The facility/ANL-E intercom and the 20 ton polar crane are also operational.

The EBWR facility will be converted into an interim storage facility for transuranic waste. At the completion of the EBWR D\&D project the facility is ready for this conversion. 


\section{CONCLUSIONS, RECOMMENDATIONS, AND LESSONS LEARNED}

The completion of the EBWR D\&D project signaled the release of the EBWR shell and surrounding area from EM-40 control. At this time, initial preparations by EM-30 for the conversion of the facility to an interim transuranic waste storage facility have begun. It is recommended that the EBWR facility be treated as a clean, free-released facility in accessible areas, and that plans for conversion continue, considering that some piping and other existing systems may be contaminated.

\subsection{GENERAL PROBLEMS ENCOUNTERED AND LESSONS LEARNED}

The decontamination of a nuclear reactor has associated with it many unforeseeable difficulties that may be unique to a particular facility. However, the solution to these problems may be applicable to situations encountered during other similar D\&D projects. The following sections list problems encountered, the remediation of these problems, and lessons learned.

\subsubsection{Sling Failure during Core Assembly Lift}

During the removal of the core assembly, a series of miscommunications resulted in the assembly becoming wedged in place and requiring segmentation for removal. This miscommunication included a misinterpretation of drawing dimensions, caused when it was assumed the outer diameter dimension accounted for a plate welded to the exterior of the assembly. This plate caused the assembly to wedge during its removal. Additionally, although an individual was observing the lift, his position and perception of the lift did not allow him to notice the assembly had wedged. Thus the lift continued, two of the four slings failed, and the assembly became stuck in place.

\subsubsection{Inability to Strike and Maintain an Arc Underwater}

An underwater plasma arc was used during the segmentation of reactor internals in the fuel pool. Initial difficulty arose when striking an arc in the pool. Due to the chemistry of the water and the presence of metallic filings, the pool water was highly conductive, preventing the formation of the underwater arc. Once different combustible gases were used to compensate for this conductivity, there were no difficulties striking the arc. 


\subsubsection{Electric Shock during Underwater Plasma Arc Use}

Three individuals were used to cut part of a reactor core shroud from the main body. One individual was responsible for cutting operations, a second individual held the segmented piece with grips connected to a 25 -ft extension, and the third individual observed the operation and controlled the power to the plasma arc torch. The grips and extension were constructed of metal, and the worker wore sweaty protective clothing. Additionally, he was leaning against a metallic guardrail during the operation. It is speculated that once the segmented piece broke away from the shroud, electrical ground shifted to the metallic grips. The current ran up the grips and formed a connection through the man's body to the guardrail. The observer cut power to the torch immediately and no one was injured. Insulation was placed on the guardrail and floor area, and insulating segments were placed in all tools associated with the plasma arc. No further electrical shock incidences occurred.

\subsubsection{Near Miss of Plasma Arc Operator Falling into the Fuel Pool}

During routine operations, an individual was making underwater cuts on the core assembly. His torch became stuck on an obstruction and while trying to free the torch, he lost his balance and released the torch handle. In an attempt not to fall into the pool, he jumped from the South side of the pool to the North side (approximately $1.5 \mathrm{~m}(5 \mathrm{ft})$ ). The safety lanyard pulled taut and pulled him backwards into the pool. The individual was immersed to his knees, but in a different trajectory, he might have hit a leg on supporting columns in the pool.

OSHA regulations had been interpreted as requiring fall protection, i.e., full body harness

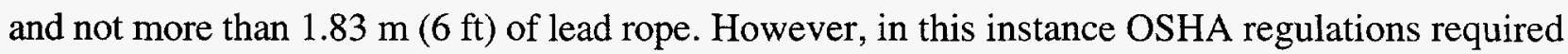
the man not break the plane of the opening, i.e., not more than 0.3-0.6 m (1-2 ft) of lead rope. Only the man's lower legs went into the pool. He was uninjured and received no additional dose. These regulations are now more fully understood, and all workers were trained for this potentially dangerous situation.

\subsubsection{Smoldering Wood in Bioshield}

A wooden blast shield was in place at the EBWR facility. Decontamination personnel were not following the specifics of the burn permit, resulting in hot embers falling on the wood. Although precautions were taken to extinguish all hot embers (the wood was thoroughly wetted with a hydro spray, left standing for two hours, and hydro sprayed again), a hot ember continued to smolder. Small amounts of smoke were found emanating from the wood blast shield the next day. The fire department was called in and the section of wood was removed without incident. Training was changed to formally incorporate specifics of all permits during the pre-job briefing. 


\subsubsection{BROKK Machine Contaminated}

During the concrete demolitions, the BROKK machine was thoroughly wrapped in protective plastic to prevent contaminated dust from penetrating the machine. However, during the demolition, the machine broke down, and to gain access to the malfunctioning parts the integrity of the plastic covering was broken. This integrity was not reestablished before work recommenced, resulting in the contamination of the machinery. The result was a long decontamination process and added expense.

\subsubsection{Cleanout and Decontamination of the Fuel Pool More Difficult than Expected}

The original concept for cleaning the fuel pool after the completion of cutting operations was a three-part process: 1) Grips attached to a pole would be used to remove large pieces of slag; 2) a dustpan-like scoop would be used to remove medium size pieces; and 3) a hydro vacuum would be used to remove the fine tailings that remained. The entire operation was estimated to take 80 hours. However, many large pieces were hidden by the finer tailings, and were difficult to maneuver when found. The dustpan scoop was also very difficult to maneuver, and remained ineffectual at the surface of the slag rather than penetrating and gathering the slag. Finally, the hydro vacuum became clogged due to the presence of the larger material. The result was the cleanup of the fuel pool took much longer than anticipated. Contamination control problems also occurred during transfer of slag filled baskets and disassembly of system packaging. This caused delays in scheduled work while surveys were used to identify and ensure complete clean up the small, spherical metal pieces of slag. The cause of this problem was attributed to inadequate contamination control and inadequate survey methods/procedures. These slag pieces were hollow, extremely small and easily scattered. They would not stick to smear paper and were difficult to detect due to high background radiation.

One method that may be used to contain the slag would be to perform all cutting operations over a basket in the pool. For the EBWR facility, however, the entire core assembly was removed in one lift rather than in segments as originally envisioned. While this would reduce the overall exposure to personnel lifting the material, it would also make cutting of the structure much more difficult. The size of the intact assembly also precluded the use of a catch basket. Additionally, inexperienced plasma arc operators may have created unnecessary slag during the initial cuts.

\subsection{RECOMMENDED APPROACHES TO WASTE PACKAGING}

Many improvements to waste packing were made during the project that resulted in much greater packing efficiencies, which yielded overall project cost savings. The approaches discussed below were incorporated in the D\&D of the EBWR facility. 


\subsubsection{High Density Waste Bins for Metal and Bioshield Concrete}

According to the original work plan, $1.93 \mathrm{~m}^{3}\left(68 \mathrm{ft}^{3}\right)$ bins with an $3636.4 \mathrm{~kg}(8,000 \mathrm{lb})$ weight capacity were to be used to load concrete and metal. The weight limit would be reached long before the volume was filled, resulting in large amounts of void space. A decision was made to use $1.36 \mathrm{~m}^{3}\left(48 \mathrm{ft}^{3}\right)$ bins with a $4545.5 \mathrm{~kg}(10,000 \mathrm{lb})$ weight capacity. The result was an increase in material placed in each box and a decrease in the amount of void space.

\subsubsection{Compactible Trash to Fill Voids in All Bins}

Compactible trash (i.e., used protective clothing, wipe down rags, etc.) was used to fill the void spaces that remained in the high weight capacity bins.

\subsubsection{Hoods to Allow Trash Placement with HEPA Ventilation Protection}

The use of simple HEPA ventilated hoods resulted in portable, inexpensive, and extremely effective hazard reduction.

\subsubsection{Hardware Baskets for Easy Handling and Rapid Draining}

Hardware baskets allowed for easier manipulation of irradiated hardware and transfer from the fuel pool to a 208 liter ( 55 gallon) drum.

\subsubsection{Shield with Remotely Operated Winches for Control Rods, Hardware Baskets, and 55 Gallon Drums}

All control rods and hardware baskets were transferred to 208 liter ( 55 gallon) drums using shields that reduced exposure to personnel. The drums were then transferred to a storage shield using a specially designed shielded vacuum transport system. Thus the greatest exposure to personnel was encountered when bolting shut the 55 gallon drums after transfer from the fuel pool.

\subsubsection{Special Liners for Core Support Plate}

Difficulty arose when attempting to section the core support plate due to the geometry of the plate. The decision was made to use a special liner to pack the plate intact. This eliminated the expense and additional exposure that would have been incurred while sectioning the plate. 
It was noted that packing of the irradiated hardware would have been easier and less costly if the baskets had been placed directly into the liner used for the core support plate instead of placing each basket into a drum and placing the drum into an overpack. The core support plate liner storage cask provided greater shielding than the drum shield. The drum shield would not have been needed as the basket could have been placed directly in the liner. Additionally, a lower overall dose would have been received when sealing the liner as opposed to sealing each individual drum. Examining all waste packing options before deciding on a course of action was advantageous.

\subsection{LESSONS LEARNED PERTAINING TO $\mathrm{Am}^{241}$ UNEXPECTED UPTAKE}

The unexpected uptake of $\mathrm{Am}^{241}$ in some workers caused major delays and cost increases that would not have been incurred otherwise. This problem reinforces the need to maintain and review all records and historical operational data. This information is essential to complete the characterization of a facility before initiation of $D \& D$ activities. The following are lessons learned which apply to all D\&D projects in general and DOE D\&D projects in particular.

\subsubsection{Prevention and Early Detection}

- Monitor to Detect Nuclides Reasonably Expected Based on Past Operations, Even If They're Not Found in Characterization

During the D\&D of a radiological facility, and especially in an experimental facility, radionuclides that were not expected may be encountered. Full alpha and gamma spectroscopy of air samples is necessary to detect radionuclides that may be present, even if they were not detected in the initial characterization.

- Thorough Knowledge of Historic Operations is the Key Factor of Quality Characterization, Especially at Experimental Facilities

The lack of detailed documentation for the EBWR reactor operations significantly impeded the characterization and subsequent D\&D activities for this project. The lack of detailed drawings resulted in conservative assumptions in the cost estimate, including the waste volumes, activity durations, and personnel exposure. The lack of accurate records from the operational period resulted in an incomplete characterization of the facility, which may have contributed to the unexpected $\mathrm{Am}^{241}$ uptake.

- Establish Personal Protective Equipment Levels Conservatively By conservatively choosing personal protective equipment, initial uptakes to unknown radionuclides may be reduced or avoided. Once it has been shown a particular task will not expose workers to unexpected uptake, the PPE levels can be reduced. 
- Expand Use of Scheduled Bioassays

Bioassays are the only way of concl ely showing the presence and levels of an internal uptake. Greater frequency en ures a more accurate assessment of internal uptake.

- Ensure Bioassay Data Reaches Key Managers in Timely Fashion

Bioassay data must have a quick turnaround time and must be reported to line managers in a timely fashion to ensure appropriate corrective actions are taken. This is the only way to ensure workers do not continue to receive an unexpected uptake after the initial exposure.

- Better Quality Air Monitoring and Dosimetry Equipment is Desirable and Cost Effective

The benefits of quality air monitoring and dosimetry equipment far outweigh the added expense. Quality air monitoring with prompt turnaround time will provide an accurate historical record of unexpected uptakes and airborne radioactivity. Quality dosimetry equipment will provide a quick warning system if radiation levels increase unexpectedly.

\subsubsection{Recovery Issues}

- Investigation Committees Should be Preselected, Trained and Dedicated to the Investigation Function

For the $\mathrm{Am}^{241}$ incident, an ad hoc investigative committee was formed after the incident occurred. This required individuals to interrupt their normal schedule to become familiar with the specific issues at hand. It is suggested that a potential investigative committee, trained in formal investigative techniques, be formed at the beginning of a D\&D project. This will allow greater freedom in choosing individuals with backgrounds appropriate to the potential hazards, and allow them greater flexibility to become familiar with the particulars of a specific $D \& D$ project and adjust their schedules as needed. By ensuring the investigation committee fully understand the issues at hand and are dedicated to the $D \& D$ project, recovery from the incident will proceed in a quick and timely fashion and incur minimal additional expense.

- Improvement in Recovery Procedure Roles is Desirable

The precise role and function of the investigative committee should be detailed in formal procedures. Included in these procedures should be the limits of authority the investigative committee has. The procedures should delineate to what extent the committee can use project funds and direct project management. If an unexpected uptake does occur and an investigation committee is established, all parties involved 
must have a clear understanding of each groups overall goals, functions, and authority. This is essential to avoid confusion and ensure a clear course of action is taken which is dedicated to determining the cause of the unexpected uptake and methods to prevent a recurrence, and will ensure recovery from the incident will proceed in a quick and timely fashion and incur minimal additional expense.

- "Surge" Analytic Capability is Needed for Sample Analysis

In a recovery situation, quick analytical turnaround time is essential to keep overrun costs down. Ideally, an on-site laboratory dedicated to the project will be available. If not, a laboratory that can provide a quick turnaround is essential.

\subsubsection{Management Issues}

- Clear Consensus on Balancing Internal Exposure Against Other Health and Cost Variables

Anticipated internal exposures should be calculated using a 50-year Committed Effective Dose Equivalent (CEDE). The CEDE should then be added to the anticipated exposure dose to develop the Total Effective Dose Equivalent (TEDE). ALARA philosophy requires that the for a given task the TEDE be as low as reasonably achievable. Currently, the internal dose may be viewed as more harmful than direct exposure. The result may be a lower CEDE but a higher overall TEDE, which is against ALARA philosophy and may incur a higher cost. The bias against an internal dose at all cost should be corrected to maintain ALARA philosophy.

- Facilities Undergoing D\&D Should be Accurately Categorized as Nuclear or Radiological Facility, with Status Updates Periodically By definition, Nuclear Facilities require much more stringent regulations and requirements be fulfilled than a Radiological Facility. The EBWR was initially classified as a Nuclear Facility, although it met all requirements for the lesser status Radiological Facility. Unnecessary paperwork and expenses would have been saved had the facility not been over classified.

\subsubsection{Noteworthy Practices}

- Prompt Response by Laboratory Project Manager Mitigated Exposure By stopping work at the first sign of unexpected uptake, further internal dose was avoided. 
- Entry and Exit Bioa ly Data s s Extremely Valuable Bioassay data is extr ely imporint when tracking the areas of greatest uptake. By correlating bioassay : a, air sampling data and RWP sign-ins, the locations of greatest uptake could be pinf ed, including identification of the specific tasks which released the airborne radiont $\cdots$ es and the pathways of exposure. This data was then used to reconstruct the even prevent or mitigate further occurrences.

- Archiving of Air Reconstruction

Air samples were $\mathrm{t}$ were taken dependiı air samples and bi could be determine

- Excellent Record All contractor air $s$ the project. This incident.

\section{ples Was Key to Dose Assessment and Event}

daily by the contractor, and sometimes multiple air samples the tasks being performed. By using the information from the , data, event reconstruction and accurate dose assessments a Helped Understand and Reconstruct Events $s$ and area surveys were accurately filed and archived during tted the review of these records while reconstructing the

\subsection{D\&D LESSONS LEAF}

The following are sig: their surplus facilities.

lessons learned that may help others to more effectively D\&D

- Continuous Sa:

\section{ience at the Job Site}

Either the Labo Project Manager, Project Engineer, Field Engineer or Safety Engineers were win the shell most of the time to observe ongoing activities. All project personnel not in the shell were predominantly in the temporary trailers just outside the shell. Additionally, either the contractor Project Manager or the contractor Health and Safety Manager were in the shell at all times. During potentially dangerous activities (i.e., operation of the plasma arc), an assigned safety observer was used to stop work in case of an emergency. These safety precautions resulted in no significant injuries to personnel.

- "Niche" Contractors Can Be Very Productive

Contractors to complete certain activities reduced both the overall cost and time expenditure of the project. Contractor personnel may have expertise in needed areas that are unavailable at ANL-E, and they are economically competitive. 
- Continuous Review of Lessons Learned

D\&D projects on the scale of the EBWR D\&D will run into unforeseeable complications and difficulties. Additionally, certain procedures may be significantly improved in both time and cost expenditures once inefficiencies are reformed. By continuously reviewing the lessons learned, mistakes and/or inefficiencies can be corrected earlier, resulting in a smoother, less costly and more productive project. 


\section{REFERENCES}

(1) An Evaluation of Alternative Reactor Vessel Cutting Technologies for the Experimental Boiling Water Reactor at Argonne National Laboratory - L. Boing et. al., December 1989, ANL-89/31.

(2) Environmental Safety and Health Manual- ES\&H Division, Revised September 1995.

(3) DOE/EV-0132, Environmental Compliance Guide - Provides draft guidance to facilitate DOE operations' compliance with NEPA and other environmental requirements.

(4) DOE N 5480.11, Radiological Control Manual - Provides all worker safety guidelines, ALARA procedures, and radiation controls.

(5) DOE Order 1324.2A, Records Disposition - Provides records implementing instructions, records inventory requirements, disposition schedules and provisions for the transfer of records.

(6) DOE Order 4700.1, Project Management System - Establishes the principles and requirements that govern the development, approval, and execution of the DOE Project Management System.

(7) DOE Order 5400.1, General Environmental Protection Program - Establishes the environmental protection program for DOE operations.

(8) DOE Order 5400.3, Hazardous and Radioactive Mixed Waste Program - Establishes DOE hazardous and radioactive mixed waste policies and requirements and implements the requirements of RCRA within the framework of the environmental programs established under DOE Order 5400.1.

(9) DOE Order 5400.5, Radiation Protection of the Public and the Environment - Establishes standards and requirements for DOE operations with respect to protection of members of the public and the environment against undue risk from radiation.

(10) DOE Order 5440.1D, National Environmental Policy Act Compliance Program - Establishes DOE policy for implementation of the NEPA of 1969.

(11) DOE Order 5480.1B, Environment, Safety and Health Program for Department of Energy Operations - Provides requirements of environmental monitoring consisting of water effluent 
measurements, ambient air monitoring, and soil, water, sediment, and grass sampling and analysis.

(12) DOE Order 5480.3, Safety Requirements for the Packaging and Transportation of Hazardous Material, Hazardous Substances, and Hazardous Wastes - Describes the requirements for packaging and transportation of hazardous material, hazardous substances and hazardous wastes.

(13) DOE Order 5480.4, Environmental Protection, Safety, and Health Protection Standards Specifies the application of mandatory ESH standards to DOE operations.

(14) DOE Order 5480.10, Contractor Industrial Hygiene Program - Establishes requirements and guidelines applicable to DOE contract operations for maintaining an effective industrial hygiene program.

(15) DOE Order 5480.11, Radiation Protection for Occupational Workers - Establishes radiation protection standards and program requirements to protect workers from ionizing radiation.

(16) DOE Order 5480.23, Nuclear Safety Analysis Reports - Establishes requirements to develop safety analyses that evaluate the adequacy of the safety bases of the facilities.

(17) DOE Order 5482.1B, Environment, Safety, and Health Appraisal Program - Establishes the DOE environment, safety, and health appraisal program.

(18) DOE Order 5483.1A, Occupational Safety and Health Program for DOE Employees at Government-Owned, Contractor-Operated Facilities - Establishes requirements for the protection of the health and safety of employees at DOE contractor-operated facilities.

(19) DOE Order 5700.6C, Quality Assurance - Establishes quality assurance requirements for the DOE.

(20) DOE Order 5820.2A, Radioactive Waste Management - Establishes policies and guidelines for the management of radioactive waste and contaminated facilities.

(21) Title 10 CFR Part 20, Standards for Protection Against Radiation - Establishes federal occupational and non-occupational radiological limits and standards (limits effective 1/1/94).

(22) Title 29 CFR Part 1910, Labor - Establishes OSHA limits, procedures and requirements for labor exposed to hazardous materials over an extended time (i.e., regular working conditions). 
(23) Title 29 CFR 1926, Labor - Establishes OSHA limits, procedures and requirements for labor exposed to hazardous materials during construction and demolition.

(24) Title 40 CFR Part 1508.4, CEQ Regulations for Implementing the Procedural Provisions of NEPA - Requirements Federal agencies must follow to achieve the goals of NEPA.

(25) Title 49 CFR parts 100 to 177 , Transportation - Establishes federal requirements for shipment and transportation of radioactive waste.

(26) NUREG/CR - 5849, Manual for Conducting Radiological Surveys in Support of License Termination (Draft, 1992).

(27) Argonne Illinois Site Transportation Safety Manual.

(28) ANL 91/3 - ANL-E Site Environmental Report for CY 1990. 
APPENDIX A:

WASTE SHIPMENTS 1986-1995 
Table A.1 EBWR Waste Shipments 1986-1991

\begin{tabular}{|c|c|c|c|c|c|c|c|}
\hline \multirow{2}{*}{\multicolumn{2}{|c|}{ 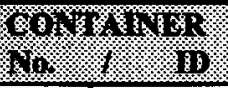 }} & \multirow{3}{*}{$\frac{M 3 A B i n}{M}$} & \multirow{3}{*}{$\frac{136}{136}$} & \multirow{3}{*}{$\frac{\text { WITF" }}{3500}$} & \multirow{2}{*}{ mol, } & \multirow{2}{*}{ 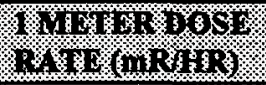 } & \multirow{2}{*}{ 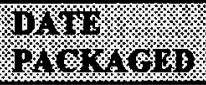 } \\
\hline & & & & & & & \\
\hline 1 & $3 \mathrm{~A} 290$ & & & & 0.3 & 1 & $2 / 28 / 86$ \\
\hline 2 & $3 \mathrm{~A} 243$ & M3A Bin & 136 & 3500 & 0.007 & 1 & $2 / 28 / 86$ \\
\hline 3 & 3A289 & M3A Bin & 136 & 6200 & 0.2 & 1 & $5 / 1 / 86$ \\
\hline 4 & $3 \mathrm{A374}$ & M3ABin & 136 & 2600 & 0.05 & 1 & $5 / 1 / 86$ \\
\hline 5 & $3 \mathrm{A378}$ & M3A Bin & 136 & 7400 & 0.2 & 1 & $5 / 14 / 86$ \\
\hline 6 & $3 \mathrm{A365}$ & M3A Bin & 136 & 7200 & 0.2 & $<1$ & $8 / 5 / 86$ \\
\hline 7 & $3 \mathrm{A382}$ & M3A Bin & 136 & 5400 & 0.25 & 4 & $8 / 26 / 86$ \\
\hline 8 & 3A397 & M3ABin & 136 & 5200 & 0.02 & $<1$ & $8 / 29 / 86$ \\
\hline 9 & $3 \mathrm{A371}$ & M3ABin & 136 & 4200 & 0.2 & 15 & $9 / 2 / 86$ \\
\hline 10 & $3 \mathrm{A380}$ & M3ABin & 136 & 6500 & 0.08 & 1 & $8 / 3 / 87$ \\
\hline 11 & $3 \mathrm{A399}$ & M3A Bin & 136 & 6900 & 0.034 & 1 & $8 / 27 / 87$ \\
\hline 12 & $3 \mathrm{~A} 401$ & M3ABin & 136 & 7700 & 0.048 & 1 & $9 / 30 / 87$ \\
\hline 13 & $3 \mathrm{~A} 394$ & M3ABin & 136 & 7400 & 0.033 & 1 & $1 / 27 / 88$ \\
\hline 14 & $3 \mathrm{A686}$ & M3A Bin & 136 & 4200 & 9 & 2 & $3 / 16 / 88$ \\
\hline 15 & $3 \mathrm{~A} 678$ & M3A Bin & 136 & 6000 & 0.5 & $<1$ & $4 / 11 / 88$ \\
\hline 16 & $3 \mathrm{~A} 680$ & M3A Bin & 136 & 5800 & 0.036 & $<1$ & $5 / 16 / 88$ \\
\hline 17 & $3 \mathrm{~A} 679$ & M3A Bin & 136 & 7000 & 0.027 & $<1$ & $5 / 20 / 88$ \\
\hline 18 & $3 \mathrm{~A} 685$ & M3ABin & 136 & 5800 & 11 & 9 & $6 / 7 / 88$ \\
\hline 21 & $3 \mathrm{~A} 665$ & M3ABin & 136 & 6000 & 5 & $<1$ & $6 / 14 / 88$ \\
\hline 19 & $3 \mathrm{~A} 417$ & M3ABin & 136 & 4400 & 0.75 & $<1$ & $6 / 18 / 88$ \\
\hline 22 & $3 \mathrm{~A} 656$ & M3A Bin & 136 & 7000 & 22 & $<1$ & $7 / 7 / 88$ \\
\hline 20 & 3A691 & M3A Bin & 136 & 5300 & 5 & $<1$ & $7 / 8 / 88$ \\
\hline 23 & $3 \mathrm{~A} 623$ & M3A Bin & 136 & 5100 & 51 & 6 & $7 / 27 / 88$ \\
\hline 24 & $3 \mathrm{~A} 645$ & M3A Bin & 136 & 1900 & 2 & 2 & $7 / 28 / 88$ \\
\hline 25 & $3 \mathrm{~A} 630$ & M3A Bin & 136 & 5500 & 15 & 4 & $8 / 22 / 88$ \\
\hline 27 & 3A571 & M3A Bin & 136 & 4100 & 0.04 & 1 & $9 / 23 / 88$ \\
\hline 26 & $3 \mathrm{A659}$ & M3A Bin & 136 & 7000 & 32 & 1 & $9 / 27 / 88$ \\
\hline 28 & 3A588 & M3A Bin & 136 & 5200 & 0.2 & 1 & $10 / 5 / 88$ \\
\hline 29 & 3 A575 & M3A Bin & 136 & 6700 & 11 & 1 & $10 / 14 / 88$ \\
\hline 30 & 3 A583 & M3A Bin & 136 & 6200 & 0.2 & 1 & $10 / 20 / 88$ \\
\hline 32 & $3 \mathrm{~A} 614$ & M3A Bin & 136 & 6200 & 5 & 1 & $11 / 4 / 88$ \\
\hline 33 & 3 A581 & M3A Bin & 136 & 6600 & 85 & 30 & $3 / 10 / 89$ \\
\hline 34 & $3 \mathrm{~A} 613$ & M3A Bin & 136 & 7800 & 36 & 3 & $3 / 31 / 89$ \\
\hline 36 & $3 \mathrm{~A} 735$ & M3ABin & 136 & 7600 & 15 & 1 & $4 / 4 / 89$ \\
\hline 31 & $3 \mathrm{~A} 586$ & M3ABin & 136 & 7400 & 2 & 1 & $4 / 5 / 89$ \\
\hline 37 & $3 \mathrm{A709}$ & M3ABin & 136 & 7400 & 54 & 6 & $4 / 21 / 89$ \\
\hline 38 & $3 \mathrm{A706}$ & M3A Bin & 136 & 7000 & 0.4 & 3 & $6 / 19 / 89$ \\
\hline 40 & $3 \mathrm{~A} 807$ & M3A Bin & 136 & 8000 & 5 & $<1$ & $10 / 6 / / 89$ \\
\hline 39 & $3 \mathrm{~A} 848$ & M3A Bin & 136 & 7800 & 0.09 & $<1$ & $11 / 8 / 89$ \\
\hline 41 & 3A919 & M3A 1/2 Bin & 68 & 7500 & 2 & 1 & $11 / 28 / 89$ \\
\hline 42 & $3 \mathrm{~A} 1019$ & M3A $1 / 2$ Bin & 68 & 6800 & 5 & 3 & $12 / 5 / 89$ \\
\hline
\end{tabular}


Table A.1 EBWR Waste Shipments 1986-1991 (con't)

\begin{tabular}{|c|c|c|c|c|c|c|c|}
\hline \multicolumn{2}{|c|}{ 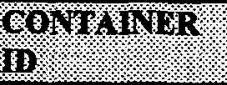 } & Mq⿴囗十⺝ & $8 \%$ & W1G11\% & TOMII. & 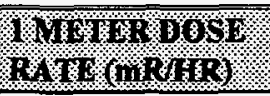 & 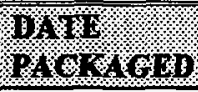 \\
\hline 43 & $3 \mathrm{~A} 1029$ & M3A $1 / 2$ Bin & 68 & 6500 & 14 & 8 & $12 / 11 / 89$ \\
\hline 44 & $3 \mathrm{~A} 1028$ & $\mathrm{M} 3 \mathrm{~A} 1 / 2 \mathrm{Bin}$ & 68 & 7100 & 4 & 2 & $12 / 11 / 89$ \\
\hline 45 & $3 A 1020$ & $\mathrm{M} 3 \mathrm{~A} 1 / 2 \mathrm{Bin}$ & 68 & 6900 & 2 & 1 & $12 / 14 / 89$ \\
\hline 46 & 3A999 & $\mathrm{M} 3 \mathrm{~A} 1 / 2 \mathrm{Bin}$ & 68 & 6800 & 18 & 11 & $1 / 29 / 90$ \\
\hline 47 & $3 \mathrm{~A} 917$ & $\mathrm{M} 3 \mathrm{~A} 1 / 2 \mathrm{Bin}$ & 68 & 6900 & 5 & 3 & $1 / 29 / 90$ \\
\hline 48 & $3 \mathrm{A965}$ & M3A Bin & 136 & 7000 & 3 & 1 & $1 / 29 / 90$ \\
\hline 35 & $3 A 727$ & M3A Bin & 136 & 1700 & 2 & 10 & $3 / 21 / 90$ \\
\hline 50 & 3A961 & M3A $1 / 2$ Bin & 68 & 5000 & 0.2 & $<1$ & $4 / 23 / 90$ \\
\hline 51 & $3 \mathrm{~A} 989$ & $\mathrm{M} 3 \mathrm{~A} 1 / 2 \mathrm{Bin}$ & 68 & 4400 & 1.5 & 6 & $11 / 13 / 90$ \\
\hline 52 & $3 \mathrm{~A} 997$ & M3A 1/2 Bin & 68 & 6100 & 0.5 & 2 & $11 / 13 / 90$ \\
\hline 53 & 3A998 & M3A $1 / 2 \mathrm{Bin}$ & 68 & 5200 & 2 & 5 & $11 / 13 / 90$ \\
\hline 54 & $3 \mathrm{~A} 722$ & M3ABin & 136 & 6800 & 0 & 0 & $11 / 26 / 90$ \\
\hline 55 & $3 \mathrm{A826}$ & M3A Bin & 136 & 2000 & $<0.1$ & 0 & $1 / 10 / 91$ \\
\hline 49 & 3A893 & M3A Bin & 136 & & & & $5 / 2 / 91$ \\
\hline 綮 & & 玹 & 6732 & 319,400 & 428.2 & & (x) \\
\hline
\end{tabular}


Table A.2 Low Level Waste Shipments Between 1994-1996

\begin{tabular}{|c|c|c|c|c|c|c|}
\hline (13) & $\sqrt[3]{19+}$ & 19 & 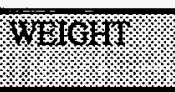 & 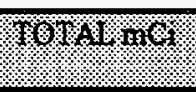 & 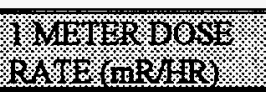 & 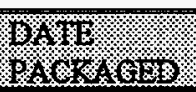 \\
\hline 27031 & M3A $1 / 2$ Bin & 68 & 2400 & 0.0014 & 0.02 & $4 / 18 / 94$ \\
\hline 26193 & M3A 1/2 Bin & 68 & 1600 & 0.49 & 0.5 & $4 / 18 / 94$ \\
\hline 43769 & M3A $1 / 2$ Bin & 68 & 5000 & 164 & 8 & $5 / 5 / 94$ \\
\hline 43771 & M3A $1 / 2 \mathrm{Bin}$ & 68 & 3400 & 82 & 4 & $5 / 18 / 94$ \\
\hline 43780 & E-48 & 48 & 3600 & 30.7 & 1.5 & $5 / 25 / 94$ \\
\hline 43770 & $\mathrm{M} 3 \mathrm{~A} 1 / 2 \mathrm{Bin}$ & 68 & 2800 & 82 & 4 & $5 / 26 / 94$ \\
\hline 43773 & E-48 & 48 & 4800 & 123 & 6 & $5 / 31 / 94$ \\
\hline 43779 & M3A $1 / 2 \mathrm{Bin}$ & 68 & 1300 & 61.5 & 3 & $6 / 2 / 94$ \\
\hline 43775 & E-48 & 48 & 3000 & 205 & 10 & $6 / 2 / 94$ \\
\hline 43802 & E-48 & 48 & 6400 & 41 & 2 & $6 / 9 / 94$ \\
\hline 43777 & E-48 & 48 & 5200 & 205 & 10 & $6 / 9 / 94$ \\
\hline 43778 & M3A 1/2 Bin & 68 & 5000 & 61.5 & 3 & $6 / 10 / 94$ \\
\hline 43782 & $E-48$ & 48 & 6000 & 102.5 & 5 & $6 / 13 / 94$ \\
\hline 43781 & M3A 1/2 Bin & 68 & 6200 & 164 & 8 & $6 / 13 / 94$ \\
\hline 43784 & E-48 & 48 & 4800 & 4.1 & 0.2 & $6 / 14 / 94$ \\
\hline 43785 & $E-48$ & 48 & 6600 & 20.5 & 1 & $6 / 14 / 94$ \\
\hline 43788 & $\mathrm{M} 3 \mathrm{~A} 1 / 2 \mathrm{Bin}$ & 68 & 7800 & 0.02 & 0.02 & $6 / 17 / 94$ \\
\hline 43790 & M3A $1 / 2$ Bin & 68 & 7000 & 0.02 & 0.02 & $6 / 17 / 94$ \\
\hline 43791 & M3A $1 / 2 \mathrm{Bin}$ & 68 & 7500 & 0.02 & 0.02 & $6 / 17 / 94$ \\
\hline 43792 & $\mathrm{M} 3 \mathrm{~A} 1 / 2 \mathrm{Bin}$ & 68 & 7000 & 0.02 & 0.02 & $6 / 17 / 94$ \\
\hline 43793 & $\mathrm{M} 3 \mathrm{~A} 1 / 2 \mathrm{Bin}$ & 68 & 8000 & 0.02 & 0.02 & $6 / 17 / 94$ \\
\hline 43794 & $\mathrm{M} 3 \mathrm{~A} 1 / 2 \mathrm{Bin}$ & 68 & 7200 & 0.02 & 0.02 & $6 / 17 / 94$ \\
\hline 43796 & $\mathrm{M} 3 \mathrm{~A} 1 / 2 \mathrm{Bin}$ & 68 & 7800 & 0.02 & 0.02 & $6 / 17 / 94$ \\
\hline 43789 & M3A $1 / 2$ Bin & 68 & 7000 & 0.02 & 0.02 & $6 / 17 / 94$ \\
\hline 43797 & $\mathrm{M} 3 \mathrm{~A} 1 / 2 \mathrm{Bin}$ & 68 & 7800 & 0.02 & 0.02 & $6 / 18 / 94$ \\
\hline 43799 & $\mathrm{M} 3 \mathrm{~A} 1 / 2 \mathrm{Bin}$ & 68 & 7800 & 0.04 & 0.05 & $6 / 18 / 94$ \\
\hline 43800 & M3A $1 / 2$ Bin & 68 & 3200 & 0.07 & 0.09 & $6 / 18 / 94$ \\
\hline 43798 & M3A $1 / 2 \mathrm{Bin}$ & 68 & 7800 & 0.38 & 0.5 & $6 / 18 / 94$ \\
\hline 43803 & E-48 & 48 & 5800 & 2 & 0.1 & $6 / 24 / 94$ \\
\hline 43786 & E-48 & 48 & 6000 & 6.1 & 0.3 & $6 / 24 / 94$ \\
\hline 43804 & E-48 & 48 & 8000 & 0.01 & 0.007 & $6 / 27 / 94$ \\
\hline 43807 & $E-48$ & 48 & 5400 & 1 & 0.05 & $6 / 27 / 94$ \\
\hline 43805 & E-48 & 48 & 6200 & 1.58 & 0.077 & $6 / 27 / 94$ \\
\hline 43783 & $\mathrm{M} 3 \mathrm{~A} 1 / 2 \mathrm{Bin}$ & 68 & 7000 & 22.47 & 1.5 & $6 / 28 / 94$ \\
\hline 43806 & E-48 & 48 & 5200 & 102.5 & 5 & $6 / 28 / 94$ \\
\hline 43808 & M3A $1 / 2 \operatorname{Bin}$ & 68 & 2200 & 319.13 & 15 & $7 / 18 / 94$ \\
\hline 44500 & 55 Gal. Drum & 7.5 & 500 & 2765.82 & 130 & $7 / 25 / 94$ \\
\hline 44499 & 55 Gal. Drum & 7.5 & 550 & 7659.19 & 360 & $7 / 25 / 94$ \\
\hline 44497 & 55 Gal. Drum & 7.5 & 450 & 10637.77 & 500 & $7 / 26 / 94$ \\
\hline 44496 & $55 \mathrm{Gal}$. Drum & 7.5 & 475 & 13254.66 & 623 & $7 / 26 / 94$ \\
\hline 44494 & 55 Gal. Drum & 7.5 & 825 & 88.96 & 18 & $7 / 27 / 94$ \\
\hline
\end{tabular}


Table A.2 Low Level Waste Shipments Between 1994-1996 (con't)

\begin{tabular}{|c|c|c|c|c|c|c|}
\hline (163) & 14 & 19: & 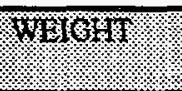 & T/4. & Thow & Priter, \\
\hline 44498 & 55 Gal. Drum & 7.5 & 780 & 1191.43 & 56 & $7 / 27 / 94$ \\
\hline 44495 & 55 Gal. Drum & 7.5 & 375 & 7935.77 & 373 & $7 / 27 / 94$ \\
\hline 44487 & 55 Gal. Drum & 7.5 & 761 & 74.13 & 15 & $8 / 11 / 94$ \\
\hline 44491 & 55 Gal. Drum & 7.5 & 632 & 291.59 & 59 & $8 / 11 / 94$ \\
\hline 44490 & 55 Gal. Drum & 7.5 & 657 & 583.18 & 118 & $8 / 11 / 94$ \\
\hline 44488 & 55 Gal. Drum & 7.5 & 628 & 8217.66 & 964 & $8 / 11 / 94$ \\
\hline 44489 & 55 Gal. Drum & 7.5 & 740 & 583.18 & 118 & $8 / 12 / 94$ \\
\hline 44492 & 55 Gal. Drum & 7.5 & 565 & 2779 & 326 & $8 / 12 / 94$ \\
\hline 44493 & E-96 & 96 & 8300 & 21.28 & 1 & $8 / 17 / 94$ \\
\hline 44485 & E-96 & 96 & 5950 & 106.38 & 5 & $8 / 22 / 94$ \\
\hline 44484 & E-96 & 96 & 8800 & 13.57 & 0.8 & $8 / 25 / 94$ \\
\hline 44483 & E-96 & 96 & 8900 & 23.74 & 1.4 & $8 / 29 / 94$ \\
\hline 44486 & E-96 & 96 & 3600 & 3.96 & 0.2 & $11 / 15 / 94$ \\
\hline 44482 & $\mathrm{M} 3 \mathrm{~A} 1 / 2 \mathrm{Bin}$ & 68 & 2500 & 2.13 & 0.1 & $11 / 18 / 94$ \\
\hline 44033 & E-96 & 96 & 8000 & 4.51 & 1 & $11 / 18 / 94$ \\
\hline 44034 & E-96 & 96 & 9100 & 4.99 & 0.5 & $11 / 18 / 94$ \\
\hline 44035 & E-96 & 96 & 9100 & 5.02 & 0.8 & $11 / 18 / 94$ \\
\hline 44036 & E-96 & 96 & 8500 & 4.67 & 1.1 & $11 / 29 / 94$ \\
\hline 44037 & E-96 & 96 & 9200 & 5.08 & 1 & $12 / 7 / 94$ \\
\hline 44038 & E-96 & 96 & 9500 & 5.17 & 1 & $12 / 7 / 94$ \\
\hline 44040 & E-96 & 96 & 9500 & 5.21 & 0.5 & $12 / 7 / 94$ \\
\hline 44039 & E-96 & 96 & 9200 & 5.06 & 1 & $12 / 8 / 94$ \\
\hline 44043 & E-96 & 96 & 2400 & 2.13 & 0.1 & $1 / 27 / 95$ \\
\hline 44042 & $\mathrm{M} 3 \mathrm{~A} 1 / 2 \mathrm{Bin}$ & 68 & 2600 & 4.26 & 0.2 & $2 / 3 / 95$ \\
\hline 44918 & 55 Gal. Drum & 7.5 & 515 & 3595.56 & 169 & $2 / 23 / 95$ \\
\hline 44919 & 55 Gal. Drum & 7.5 & 469 & 28721.97 & 1350 & $2 / 24 / 95$ \\
\hline 44920 & 55 Gal. Drum & 7.5 & 400 & 71911.29 & 3380 & $2 / 24 / 95$ \\
\hline 44921 & 55 Gal. Drum & 7.5 & 507 & 129355.22 & 6080 & $2 / 24 / 95$ \\
\hline 44923 & 55 Gal. Drum & 7.5 & 441 & 14382.26 & 676 & $2 / 27 / 95$ \\
\hline 44922 & 55 Gal. Drum & 7.5 & 561 & 244668.6 & 11500 & $2 / 27 / 95$ \\
\hline 44044 & M3A 1/2 Bin & 68 & 1650 & 2.13 & 0.1 & $3 / 24 / 95$ \\
\hline 44045 & M3A $1 / 2$ Bin & 68 & 3700 & 14.89 & 0.7 & $3 / 24 / 95$ \\
\hline 44046 & M3A $1 / 2$ Bin & 68 & 1200 & 106.38 & 5 & $4 / 3 / 95$ \\
\hline 44041 & M3A $1 / 2 \mathrm{Bin}$ & 68 & 1550 & 212.76 & 10 & $4 / 3 / 95$ \\
\hline 44049 & $7-100$ & 92 & 5600 & 12256.65 & 2480 & $4 / 25 / 95$ \\
\hline 44050 & E-96 & 96 & 2700 & 148.93 & 7 & $4 / 28 / 95$ \\
\hline 44048 & M3A $1 / 2$ Bin & 68 & 5750 & 4.26 & 0.2 & $5 / 5 / 95$ \\
\hline 950800659 & M3A $1 / 2$ Bin & 68 & 1650 & 74.46 & 3.5 & $5 / 17 / 95$ \\
\hline 950800661 & M3A $1 / 2$ Bin & 68 & 2200 & 55.32 & 2.6 & $5 / 19 / 95$ \\
\hline 950800660 & M3A $1 / 2 \mathrm{Bin}$ & 68 & 1850 & 212.76 & 10 & $5 / 19 / 95$ \\
\hline 950800662 & $7-100$ & 92 & 2636 & 51826.49 & 2400 & $6 / 27 / 95$ \\
\hline 950800664 & 55 Gal. Drum & 7.5 & 499 & 27870.94 & 1310 & $6 / 29 / 95$ \\
\hline
\end{tabular}


Table A.2 Low Level Waste Shipments Between 1994-1996 (con't)

\begin{tabular}{|c|c|c|c|c|c|c|}
\hline (6) N & $4 \%$ & W19. & mIGIII & 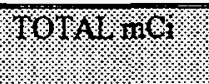 & 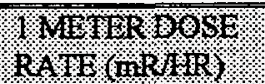 & 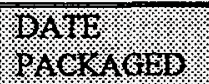 \\
\hline 950800665 & $55 \mathrm{Gal}$. Drum & 7.5 & 100 & 15318.38 & 720 & $7 / 13 / 95$ \\
\hline 950800666 & $55 \mathrm{Gal}$. Drum & 7.5 & 200 & 9573.99 & 450 & $7 / 13 / 95$ \\
\hline 950800663 & $\mathrm{M} 3 \mathrm{~A} 1 / 2 \mathrm{Bin}$ & 68 & 3150 & 10.64 & 0.5 & $7 / 17 / 95$ \\
\hline 950800668 & M3A $1 / 2$ Bin & 68 & 1650 & 6.38 & 0.3 & $7 / 17 / 95$ \\
\hline 950800669 & E-96 & 96 & 5550 & 106.38 & 5 & $7 / 19 / 95$ \\
\hline 950800670 & E-96 & 96 & 3500 & 25.53 & 1.2 & $7 / 20 / 95$ \\
\hline 950800671 & E-96 & 96 & 4250 & 31.91 & 1.5 & $7 / 22 / 95$ \\
\hline 950800672 & E-96 & 96 & 4000 & 10.64 & 0.5 & $7 / 22 / 95$ \\
\hline 950800673 & E-96 & 96 & 5600 & 148.93 & 7 & $7 / 24 / 95$ \\
\hline 950800674 & M3A $1 / 2$ Bin & 68 & 1900 & 106.00 & 5 & $7 / 25 / 95$ \\
\hline 950800675 & M3A 1/2 Bin & 68 & 1400 & 148.93 & 7 & $8 / 2 / 95$ \\
\hline 950800676 & M3A $1 / 2 \mathrm{Bin}$ & 68 & 1400 & 85.10 & 4 & $8 / 2 / 95$ \\
\hline 950800677 & M3A $1 / 2$ Bin & 68 & 1450 & 23.40 & 1.1 & $8 / 2 / 95$ \\
\hline 950800678 & M3A $1 / 2$ Bin & 68 & 3000 & 8.51 & 0.4 & $8 / 2 / 95$ \\
\hline 950800679 & M3A $1 / 2$ Bin & 68 & 2550 & 212.76 & 10 & $8 / 2 / 95$ \\
\hline 950800680 & M3A $1 / 2$ Bin & 68 & 2700 & 2.13 & 0.1 & $8 / 3 / 95$ \\
\hline 950800681 & M3A 1/2 Bin & 68 & 2500 & 17.02 & 0.8 & $8 / 4 / 95$ \\
\hline 950800682 & M3A $1 / 2$ Bin & 68 & 2350 & 6.38 & 0.3 & $8 / 4 / 95$ \\
\hline 950800684 & M3A $1 / 2 \mathrm{Bin}$ & 68 & 4400 & 2.13 & 0.1 & $8 / 4 / 95$ \\
\hline 950800683 & M3A $1 / 2$ Bin & 68 & 1450 & 255.31 & 12 & $8 / 5 / 95$ \\
\hline 950800685 & M3A $1 / 2$ Bin & 68 & 2000 & 31.91 & 1.5 & $8 / 11 / 95$ \\
\hline 950800686 & M3A $1 / 2$ Bin & 68 & 3850 & 6.38 & 0.3 & $8 / 12 / 95$ \\
\hline 950800687 & M3A $1 / 2 \mathrm{Bin}$ & 68 & 2800 & 17.02 & 0.8 & $8 / 16 / 95$ \\
\hline 950800688 & $\mathrm{M} 3 \mathrm{~A} 1 / 2 \mathrm{Bin}$ & 68 & 1300 & 21.28 & 1 & $8 / 17 / 95$ \\
\hline 950800693 & M3A $1 / 2$ Bin & 68 & 1600 & 2.13 & 0.1 & $8 / 24 / 95$ \\
\hline 950800689 & M3A $1 / 2$ Bin & 68 & 1500 & 17.02 & 0.8 & $8 / 28 / 95$ \\
\hline 950800690 & M3A $1 / 2$ Bin & 68 & 1400 & 10.64 & 0.5 & $8 / 29 / 95$ \\
\hline 950800692 & M3A $1 / 2$ Bin & 68 & 1650 & 4.26 & 0.2 & $9 / 8 / 95$ \\
\hline 950800694 & $\mathrm{M} 3 \mathrm{~A} 1 / 2 \mathrm{Bin}$ & 68 & 2100 & 14.89 & 0.7 & $9 / 8 / 95$ \\
\hline 950800695 & $\mathrm{M} 3 \mathrm{~A} 1 / 2 \mathrm{Bin}$ & 68 & 1750 & 4.26 & 0.2 & $9 / 19 / 95$ \\
\hline 950800696 & $\mathrm{M} 3 \mathrm{~A} 1 / 2 \mathrm{Bin}$ & 68 & 1500 & 6.38 & 0.3 & $9 / 20 / 95$ \\
\hline 950800697 & $\mathrm{M} 3 \mathrm{~A} 1 / 2 \mathrm{Bin}$ & 68 & 1650 & 2.13 & 0.1 & $9 / 20 / 95$ \\
\hline 960300016 & M3A $1 / 2 \mathrm{Bin}$ & 68 & 1650 & 10.64 & 0.5 & $9 / 22 / 95$ \\
\hline 960300017 & $\mathrm{M} 3 \mathrm{~A} 1 / 2 \mathrm{Bin}$ & 68 & 1950 & 2.13 & 0.1 & $9 / 22 / 95$ \\
\hline 960300018 & $\mathrm{M} 3 \mathrm{~A} 1 / 2 \mathrm{Bin}$ & 68 & 2150 & 2.13 & 0.1 & $9 / 22 / 95$ \\
\hline 960300019 & $\mathrm{M} 3 \mathrm{~A} 1 / 2 \mathrm{Bin}$ & 68 & 1800 & 2.13 & 0.1 & $9 / 26 / 95$ \\
\hline 960300020 & M3A $1 / 2 \mathrm{Bin}$ & 68 & 1800 & 0.26 & 0.012 & $9 / 26 / 95$ \\
\hline 960300023 & M3A $1 / 2 \mathrm{Bin}$ & 68 & 1850 & 2.13 & 0.1 & $9 / 26 / 95$ \\
\hline 960300024 & $\mathrm{M} 3 \mathrm{~A} 1 / 2 \mathrm{Bin}$ & 68 & 2850 & 4.26 & 0.2 & $10 / 2 / 95$ \\
\hline 960300025 & M3A $1 / 2 \mathrm{Bin}$ & 68 & 2700 & 2.13 & 0.1 & $10 / 2 / 95$ \\
\hline 960300026 & $\mathrm{M} 3 \mathrm{~A}$ I/2 Bin & 68 & 2550 & 2.13 & 0.1 & $10 / 3 / 95$ \\
\hline 960300027 & $\mathrm{M} 3 \mathrm{~A} 1 / 2 \mathrm{Bin}$ & 68 & 2000 & 2.13 & 0.1 & $10 / 16 / 95$ \\
\hline
\end{tabular}


Table A.2 Low Level Waste Shipments Between 1994-1996 (con't)

\begin{tabular}{|c|c|c|c|c|c|c|}
\hline 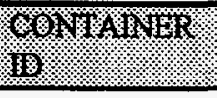 & 1.4. & 9 & 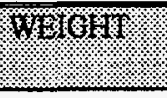 & TOMA $/ \mathrm{nO}$ & 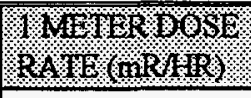 & Prick \\
\hline 960300028 & $\mathrm{M} 3 \mathrm{~A} 1 / 2 \mathrm{Bin}$ & 68 & 2450 & 8.51 & 0.4 & $10 / 18 / 95$ \\
\hline 960300029 & $\mathrm{M} 3 \mathrm{~A} 1 / 2 \mathrm{Bin}$ & 68 & 3350 & 2.13 & 0.1 & $10 / 26 / 95$ \\
\hline 960300030 & $\mathrm{M} 3 \mathrm{~A} 1 / 2 \mathrm{Bin}$ & 68 & 2100 & 2.13 & 0.1 & $10 / 26 / 95$ \\
\hline 960300031 & $\mathrm{M} 3 \mathrm{~A} 1 / 2 \mathrm{Bin}$ & 68 & 1850 & 2.13 & 0.1 & $10 / 26 / 95$ \\
\hline 960300032 & $\mathrm{M} 3 \mathrm{~A} 1 / 2 \mathrm{Bin}$ & 68 & 1850 & 2.13 & 0.1 & 11/13/95 \\
\hline 960300033 & $\mathrm{M} 3 \mathrm{~A} 1 / 2 \mathrm{Bin}$ & 68 & 2200 & 2.13 & 0.1 & $11 / 13 / 95$ \\
\hline 960300034 & $\mathrm{M} 3 \mathrm{~A} 1 / 2 \mathrm{Bin}$ & 68 & 1750 & 2.13 & 0.1 & $11 / 20 / 95$ \\
\hline 960300270 & M3A 1/2 Bin & 68 & 2100 & 2.13 & 0.1 & $12 / 20 / 95$ \\
\hline 960300035 & $\mathrm{M} 3 \mathrm{~A} 1 / 2 \mathrm{Bin}$ & 68 & 1136 & 2.13 & 0.1 & $1 / 3 / 96$ \\
\hline & & 8109.04 & 473,052 & $669,797.4914$ & & \\
\hline
\end{tabular}


Table A.3 Mixed Waste Shipments Between 1994-1996

\begin{tabular}{|c|c|c|c|c|c|c|}
\hline $1014=$ & WUE & 14 & M116. & 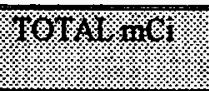 & 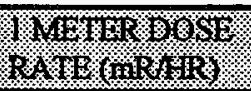 & 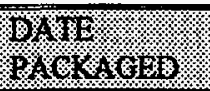 \\
\hline 26282 & 55 Gal. Drum & 7.5 & 780 & 2.07 & 0.101 & $7 / 15 / 94$ \\
\hline 26284 & 55 Gal. Drum & 7.5 & 600 & 0.7 & 0.034 & $7 / 15 / 94$ \\
\hline 26285 & 55 Gal. Drum & 7.5 & 650 & 0.1937 & 0.02 & $8 / 10 / 94$ \\
\hline 26287 & 55 Gal. Drum & 7.5 & 400 & 0.1937 & 0.02 & $8 / 10 / 94$ \\
\hline 25746 & 55 Gal. Drum & 7.5 & 800 & 0.9687 & 0.1 & $8 / 18 / 94$ \\
\hline 26286 & 55 Gal. Drum & 7.5 & 625 & 0.9687 & 0.1 & $8 / 18 / 94$ \\
\hline 26289 & 55 Gal. Drum & 7.5 & 650 & 0.9687 & 0.1 & $8 / 18 / 94$ \\
\hline 26290 & $55 \mathrm{Gal}$. Drum & 7.5 & 750 & 0.9687 & 0.1 & $8 / 18 / 94$ \\
\hline 27576 & 55 Gal. Drum & 7.5 & 725 & 1.02 & 0.1 & $8 / 22 / 94$ \\
\hline 27567 & 55 Gal. Drum & 7.5 & 575 & 1.9374 & 0.2 & $8 / 23 / 94$ \\
\hline 27568 & 55 Gal. Drum & 7.5 & 675 & 0.9687 & 0.1 & $8 / 23 / 94$ \\
\hline 27565 & 55 Gal. Drum & 7.5 & 80 & 0.2906 & 0.03 & $8 / 24 / 94$ \\
\hline 27587 & 55 Gal. Drum & 7.5 & 650 & 1.9374 & 0.2 & $8 / 24 / 94$ \\
\hline 27588 & 55 Gal. Drum & 7.5 & 750 & 1.9374 & 0.2 & $8 / 24 / 94$ \\
\hline 27592 & 55 Gal. Drum & 7.5 & 585 & 1.9374 & 0.2 & $8 / 24 / 94$ \\
\hline 27593 & 55 Gal. Drum & 7.5 & 560 & 1.9374 & 0.2 & $8 / 24 / 94$ \\
\hline 27564 & 55 Gal. Drum & 7.5 & 625 & 0.9687 & 0.1 & $8 / 24 / 94$ \\
\hline 27589 & $55 \mathrm{Gal}$. Drum & 7.5 & 725 & 0.9687 & 0.1 & $8 / 24 / 94$ \\
\hline 27590 & 55 Gal. Drum & 7.5 & 800 & 0.9687 & 0.1 & $8 / 24 / 94$ \\
\hline 27591 & 55 Gal. Drum & 7.5 & 780 & 0.9687 & 0.1 & $8 / 24 / 94$ \\
\hline 27563 & 55 Gal. Drum & 7.5 & 600 & 1.5499 & 0.16 & $8 / 24 / 94$ \\
\hline 27566 & 55 Gal. Drum & 7.5 & 750 & 1.02 & 0.1 & $8 / 24 / 94$ \\
\hline 27569 & 55 Gal. Drum & 7.5 & 775 & 1.02 & 0.1 & 9/9/94 \\
\hline 27571 & 55 Gal. Drum & 7.5 & 725 & 1.02 & 0.1 & 9/9/94 \\
\hline 27572 & 55 Gal. Drum & 7.5 & 725 & 1.02 & 0.1 & 9/9/94 \\
\hline 27575 & 55 Gal. Drum & 7.5 & 725 & 1.02 & 0.1 & 9/9/94 \\
\hline 27570 & $55 \mathrm{Gal}$. Drum & 7.5 & 625 & 0.969 & 0.1 & 9/9/94 \\
\hline 27573 & 55 Gal. Drum & 7.5 & 700 & 0.969 & 0.1 & $9 / 9 / 94$ \\
\hline 27574 & 55 Gal. Drum & 7.5 & 800 & 0.969 & 0.1 & 9/9/94 \\
\hline 27580 & 55 Gal. Drum & 7.5 & 750 & 0.969 & 0.1 & $9 / 23 / 94$ \\
\hline 27578 & 55 Gal. Drum & 7.5 & 650 & 0.969 & 0.1 & $10 / 23 / 94$ \\
\hline 27579 & 55 Gal. Drum & 7.5 & 750 & 0.969 & 0.1 & $10 / 23 / 94$ \\
\hline 26288 & 55 Gal. Drum & 7.5 & 600 & 0.969 & 0.1 & $10 / 31 / 94$ \\
\hline 27581 & 55 Gal. Drum & 7.5 & 675 & 0.969 & 0.1 & $10 / 31 / 94$ \\
\hline 27583 & 55 Gal. Drum & 7.5 & 575 & 0.969 & 0.1 & $10 / 31 / 94$ \\
\hline 27584 & 55 Gal. Drum & 7.5 & 575 & 0.969 & 0.1 & $10 / 31 / 94$ \\
\hline 27585 & 55 Gal. Drum & 7.5 & 575 & 0.969 & 0.1 & $10 / 31 / 94$ \\
\hline 27586 & 55 Gal Drum & 7.5 & 625 & 0.969 & 0.1 & $10 / 31 / 94$ \\
\hline 28782 & 55 Gal. Drum & 7.5 & 575 & 0.969 & 0.1 & $10 / 31 / 94$ \\
\hline 28783 & 55 Gal. Drum & 7.5 & 775 & 0.969 & 0.1 & $10 / 31 / 94$ \\
\hline 28784 & 55 Gal. Drum & 7.5 & 600 & 0.969 & 0.1 & $10 / 31 / 94$ \\
\hline
\end{tabular}


Table A.3 Mixed Waste Shipments Between 1994-1996 (con't)

\begin{tabular}{|r|l|r|r|r|r|r|}
\hline & & & & & \\
\hline
\end{tabular}


APPENDIX B:

SUPPLEMENTAL CORRESPONDENCE CONCERNING THE STATUS OF EBWR AT TRANSFER FROM EM-40 TO EM-30 


\section{ARGONNE \\ NATIONAL \\ LABORATORY}

Inter-Laboratory Memo

Date:

January 11,1996

To:
D. Gabel
DOE/201
J. Loomis
DOE/201
R. Coley
EWM/214
M. Sodaro
EWM/340
J. Wozniak
EWM/4

$\begin{array}{ll}\text { T. Yule } & \text { TD/207 } \\ \text { C. Fellhauer } & \text { TD/331 } \\ \text { R. Wynveen } & \text { ESH/201 } \\ \text { M. Robinet } & \text { ESH-HP/201 }\end{array}$

From:

B. Murdoch

ESH-HP/316

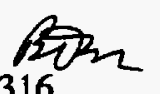

Subject:

HP RELEASE OF EBWR SHELL BUILDING FOR CONSTRUCTION PROJECT

Effective at 2:00 pm, Friday, January 12, 1996, the Experimental Boiling Water Reactor (EBWR) containment building will be reposted as a Radiologically Controlled Area, with no special entry requirements. Personnel entering the building will not be required to wear dosimeters, and no other personnel dosimetry will be required.

Any person entering this Controlled Area without escort must have current General Employee Radiation Training (GERT) or Contractor Safety Training. Those who do not have the basic training must be escorted by a properly trained ANL employee.

Health Physics has completed an independent final survey of the interior of this building, and this reposting is based on our preliminary evaluation of the survey results. A complete, detailed, final survey report will be issued by Health Physics on or before February 16, 1996.

Items of exception within the building including the following:

- The interior of the elevator shaft is posted as a Contamination Area. Entry to the shaft below the first level requires a Radiological Work Permit and protective clothing.

- The main overhead crane block and cables are contaminated. The block is tagged. The crane is to remain locked out. The air compressor on Level 3 is also to be locked out.

- All drains are labeled with "Radioactive Material" stickers. Level 1 drains are plugged. No drains are to be opened or otherwise breached without first contacting Health Physics.

(Note: the main sump on Level 1 is not contaminated).

- A number of bolted down plates and boxes which cover radioactive areas are labeled and are not to be removed. Any tagged electrical outlets or switch boxes are not to be opened without first contacting Health Physics.

- Several pipes penetrating the shell are tagged as radioactive. These pipes are not to be opened without contacting Health Physics.

With these exceptions, the building is radiologically safe for construction work. Health Physics will be conducting periodic tours of inspection to ensure the integrity of labels and postings, and we will be available to respond to any questions which might arise. 


\section{ARGONNE \\ NATIONAL \\ LABORATORY}

\section{Intra-Laboratory Memo}

January 19, 1996
EBWR D\&D/\#8

TO:

FROM:
M. Sodaro
$\mathrm{EMO} / 214$
C. Fellhauer
TD-D\&D/331,T-1

SUBJECT: $\quad$ Transfer of the Experimental Boiling Water Reactor (EBWR) from TD to EMO.

A walkdown of the EBWR was conducted this morning by representatives from $\mathrm{TD}, \mathrm{HP}$ and EMO. The transfer of the building for conversion and ultimate use by EMO was agreed upon subject to the following items and the indicated resolution.

1. Completion of labeling/posting of radiological conditions in the shell by Health Physics.

TD will remain responsible for completing the following items:

1. Arrange for the ANL carpenters to fill the holes around the fuel pool with concrete, place toe guards around the fuel pool handrails, install mid-rails over the openings from the Level 2 floor to the Reactor Cavity area and place a cover over the shell sump. A service request for this work was submitted on 1-12-96.

2. Place standard "Confined Space" signs at the Fuel Pool. These were ordered on 1-12-96.

3. Place high-visibility caution tape over the rail tracks and mounting 
brackets on the Level 1 floor. The tape was ordered on 1-12-96.

EMO will complete the following renovation during the conversion project:

1. Replace all deck grating in the shell.

2. Install upper hand rails or remove the access ladder to the lower platform area just below Level 3.

Concur:

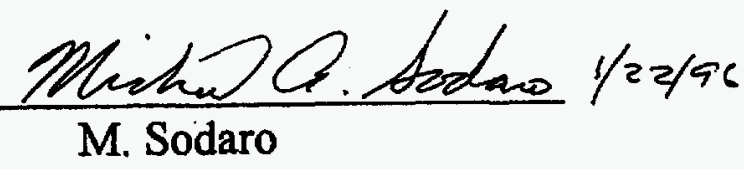

CF:amw

CC:

L. Boing

G. Borland

R. Cannon

R.Coley
A. Gabel
C. Grandy
J. Labiak
J. Loomis
J. Mezaraups
B. Murdoch
R. Pisowicz
M. Robinet
D. Wise
J. Wozniak
T. Yule
File 